\title{
POR UMA ANÁLISE COSMOPOLITA DA DETERMINAÇÃO DA LEI APLICÁVEL
}

\begin{abstract}
Dissertação de Mestrado apresentada ao Departamento de Direito Internacional da Faculdade de Direito da Universidade de São Paulo, elaborada sob a orientação do Professor Titular Paulo Borba Casella, como requisito parcial para a obtenção do título de Mestre em Direito.
\end{abstract}

Universidade de São Paulo

Faculdade de Direito

São Paulo, 2012. 


\section{POR UMA ANÁLISE COSMOPOLITA DA DETERMINAÇÃO DA LEI APLICÁVEL}

Dissertação de Mestrado apresentada ao Departamento de Direito Internacional da Faculdade de Direito da Universidade de São Paulo, elaborada sob a orientação do Professor Titular Paulo Borba Casella, como requisito parcial para a obtenção do título de Mestre em Direito.

Banca Examinadora:

Data de aprovação: 
Para Jacob Dolinger,

um construtor de pontes.

3 


\section{AGRADECIMENTOS}

Ao Professor Paulo Borba Casella, orientador desta dissertação, por ter confiado em meu projeto desde o início, bem como pelo apoio e estímulo constantes. O Professor Casella reúne duas qualidades extraordinárias para um acadêmico: vasta erudição e olhar voltado para o futuro.

Ao Professor Jacob Dolinger, a quem a presente obra é dedicada, devo tudo. Palavras não são suficientes para externar minha gratidão ao mestre, que despertou minha vocação acadêmica ainda na graduação e acompanhou de perto, desde então, meus estudos. O Professor também teceu importantes comentários e críticas durante a elaboração desta dissertação. O resultado desta obra é, no seu todo, um agradecimento ao mestre.

À Professora Carmen Tiburcio, da Universidade do Estado do Rio de Janeiro, por ter contribuído decisivamente para meu interesse pelo Direito Internacional Privado, desde o início da minha graduação. Desfrutei, no passado, de sua orientação na iniciação científica e na monografia de conclusão de curso, bem como de suas aulas apaixonantes.

À Professora Maristela Basso, por ter me acolhido, durante o Mestrado, como Estagiário Docente nas disciplinas Direito Internacional Privado e Direito do Comércio Internacional, no âmbito da graduação da Faculdade de Direito da USP. A experiência em sala de aula e o convívio com a Professora dedicada e atenciosa enriqueceram enormemente a vida deste autor.

Ao Professor Gustavo Ferraz de Campos Monaco, por sua participação decisiva na Banca do meu Exame de Qualificação. Suas críticas e sugestões foram valiosas e se refletiram no caminho que foi trilhado neste estudo.

Agradeço, ainda, a todos os demais Professores com quem convivi no Largo São Francisco, bem como aos amigos que aqui fiz. O ambiente das Arcadas fornece ao acadêmico oportunidade ímpar de troca e aprendizado.

Por fim, agradeço à minha família, sem a qual nada seria possível. 
"Para reaver, porém, todo o Universo, E amar! e crer! e achar meus mil sentidos!....

Basta-me o gesto de contar um verso."

(José Régio, Testamento do Poeta) 


\section{RESUMO}

A presente dissertação versa a teoria geral da determinação da lei aplicável no Direito Internacional Privado, sob a ótica de parâmetros cosmopolitas colhidos em outras ciências humanas, em perspectiva interdisciplinar. Analisam-se vários estudos recentes sobre o cosmopolitismo, bem como suas origens remotas, de modo a propor possíveis relações do tema com o método conflitual do Direito Internacional Privado.

No capítulo I, empreende-se estudo histórico, retornando às origens do cosmopolitismo (filosofias grega e romana), passando pelo cosmopolitismo de Kant, no séc. XVIII, para então, finalmente, examinar os cosmopolitismos contemporâneos. Quanto a estes, procede-se à uma taxionomia e se exploram algumas proposições teóricas de especial utilidade para a determinação da lei aplicável.

No capítulo II, busca-se transpor o cosmopolitismo do plano das demais ciências humanas para o plano da teoria jurídica em particular. Analisa-se, primeiro, o que implica a ideia de cosmopolitização do direito e, após, a relação entre o cosmopolitismo e o Direito Internacional Privado em específico. Dá-se especial atenção à aplicação da ideia de justiça cosmopolita no contexto da determinação da lei aplicável.

No capítulo III, trata-se dos três grandes métodos de determinação da lei aplicável (multilateralismo, unilateralismo e materialismo), em perspectivas histórica e crítica. Conclui-se que a adoção do multilateralismo enquanto estrutura principal de determinação da lei aplicável, flexibilizado pelo princípio da proximidade, atende mais à imparcialidade cosmopolita que os outros dois métodos.

No capítulo IV, propõe-se uma visão cosmopolita do princípio da ordem pública, concentrando-se em duas importantes evoluções teóricas mais recentes: as noções de ordem pública de proximidade e de ordem pública verdadeiramente internacional. Procede-se, ademais, a exame crítico da aplicação da exceção da ordem pública, no que se refere à lei aplicável, na jurisprudência brasileira recente.

Ao fim do estudo, as principais conclusões são enumeradas. 


\section{Palavras-chaves:}

Cosmopolitismo. Direito Internacional Privado. Determinação da lei aplicável. Justiça. Imparcialidade. Princípio da proximidade. Ordem pública. Direito Comparado. 


\begin{abstract}
This dissertation addresses international choice of law, through the lens of cosmopolitan standards collected from other humanities, undertaking an interdisciplinary approach. Many recent studies on cosmopolitanism are examined, as well as its remote origins, so as to propose links between choice of law and cosmopolitanism.

In chapter I, a historical study is undertaken, going back to the origins of cosmopolitanism (Greek and Roman philosophers), dealing moreover with Kant's cosmopolitanism (18th century) and contemporary cosmopolitanisms. Accordingly, a division into categories is proposed and some theoretical notions of special importance to choice of law are tackled.
\end{abstract}

In chapter II, cosmopolitan concepts are applied to legal theory. First, consequences are drawn from the idea of cosmopolitanizing law. Afterwards, the relation between Conflict of Laws and cosmopolitanism is addressed. The focus is on the application of the idea of cosmopolitan justice to choice of law.

In chapter III, the three existing choice of law methods are addressed (multilateralism, unilateralism and substantialism), historically and critically. It is concluded that the adoption of multilateralism as a general framework, flexibilized by the principe de proximité, is a better option in terms of cosmopolitan impartiality than the other two methods.

In chapter IV, a cosmopolitan vision of public policy is proposed, focusing upon two important theories recently conceived: the notions of ordre public de proximité and of truly international public policy. Also, a critical address of the recent application of the public policy exception by Brazilian courts (within the choice of law context) is made.

At the end, the main conclusions are enumerated. 


\section{Keywords:}

Cosmopolitanism. Conflict of Laws. Choice of law. Justice. Impartiality. Closest connection. Public policy. Comparative Law. 


\section{SUMÁRIO}

Introdução

Capítulo I - O marco teórico cosmopolita nas humanidades

1. Percurso histórico do cosmopolitismo ............................................................. 15

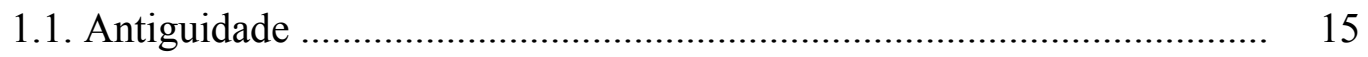

1.2. O cosmopolitismo kantiano ................................................................. 18

2. Cosmopolitismos contemporâneos ............................................................. 20

2.1. Considerações gerais ....................................................................... 20

2.2. A dualidade cosmopolita entre o universalismo e o relativismo ........... 22

2.3. Tipos de cosmopolitismo ................................................................... 26

2.4. Justiça cosmopolita e imparcialidade ................................................... 29

2.5. Alguns parâmetros cosmopolitas .......................................................... 35

2.5.1. Necessidade de avanço do cosmopolitismo empírico-analítico ..... 35

2.5.2. Indivíduo como unidade fundamental de consideração moral ....... 36

2.5.3. Imparcialidade aberta enquanto postulado teórico ....................... 38

2.5.4. Busca de equilíbrio entre uma estrutura geral de respeito à diferença e um mínimo universal ............................................................. 39

Capítulo II - Justiça cosmopolita e Direito Internacional Privado ................... 41

1. A cosmopolitização do direito ..................................................................... 41

2. Cosmopolitismo e provincianismo no Direito Internacional Privado .......... 46

3. Justiça conflitual e justiça material no Direito Internacional Privado - uma

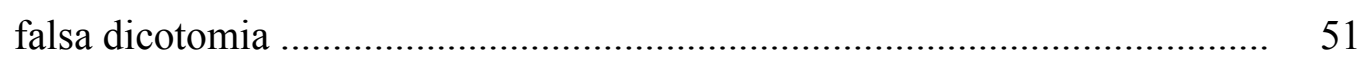

Capítulo III - Métodos de determinação da lei aplicável ................................. 56

1. Conflito de soberanias ou localização da relação jurídica privada? ............. 56

2. Multilateralismo, unilateralismo e materialismo ......................................... 59

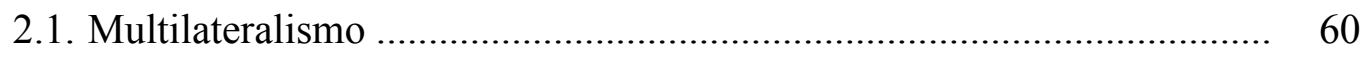

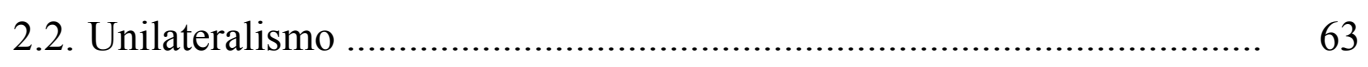

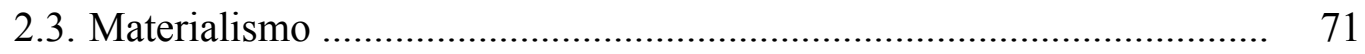


2.4. Pluralismo de métodos ...................................................................... 74

2.4.1. A flexibilização das regras de conexão ………………….......... 76

2.4.2. A publicização do direito e as lois de police ................................ 82

2.4.3. Materialismo e regras de conexão substanciais ............................ 85

2.4.4. Considerações críticas ............................................................. 87

Capítulo IV - Visão cosmopolita da ordem pública ......................................... 91

1. Aspectos gerais ...................................................................................... 91

2. Intensidade da aplicação da ordem pública em função da proximidade com

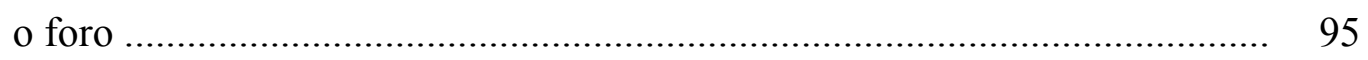

3. Ordem pública verdadeiramente internacional .......................................... 98

4. Ordem pública e determinação da lei aplicável: jurisprudência brasileira .... 104 4.1. Regime de bens ............................................................................. 104

4.2. Casamento no exterior de pessoa desquitada no Brasil ........................ 105

4.3. Dívida de jogo contraída no exterior .................................................... 107

4.4. Prazo prescricional estabelecido em lei estrangeira ............................. 109

4.5. Autonomia da vontade e ordem pública verdadeiramente internacional 110

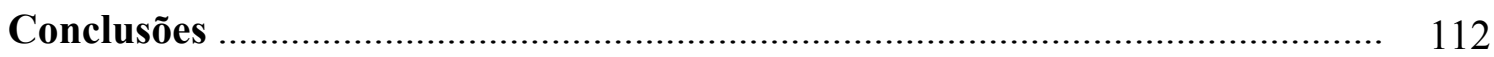

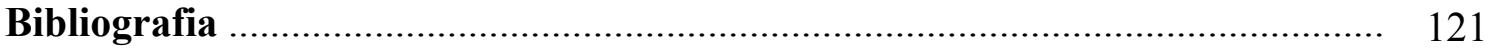




\section{INTRODUÇÃO}

Nas últimas décadas, o fenômeno da mundialização acelerou-se abruptamente. A intensificação do comércio, dos fluxos migratórios e de capitais, somada ao desenvolvimento tecnológico, facilita sobremaneira o contato entre pessoas físicas e jurídicas ligadas a ordenamentos jurídicos diversos. Houve uma verdadeira revolução dos costumes e relações em grande parte da humanidade - um dos aspectos notáveis é que a rede mundial de computadores permite que pessoas situadas nas mais distantes localidades interajam em tempo real.

O pensamento jurídico do séc. XXI precisa responder à altura a essa cosmopolitização da vida. Essa resposta passa, necessariamente, pelo Direito Internacional. Se o séc. XIX precisou do Direito Privado e o séc. XX (sobretudo a segunda metade) do Direito Constitucional, o séc. XXI necessitará, de forma aguda, do Direito Internacional. Note-se que, se é verdade que a construção de um ordenamento jurídico global ainda é uma distante utopia, cercada ademais por grandes riscos, o estabelecimento de um diálogo maior entre as diferentes culturas jurídicas revela-se um caminho viável e necessário. $\mathrm{O}$ Direito Internacional Privado possui um papel decisivo a desempenhar nesse cenário. A disciplina, como bem ensina Jacob Dolinger, leva à compreensão da diversidade, ao respeito pelo desconhecido e à tolerância com o estranho. Isso possibilita uma aproximação entre os povos, o que trará melhores condições para a paz ${ }^{1}$.

A ideia do cosmopolitismo, apesar de muito antiga, tem sido objeto de intensa discussão acadêmica nos últimos anos ${ }^{2}$. Embora não possua significado unívoco, a maioria dos autores cosmopolitas partilha a percepção de que todos os seres humanos pertencem (ou ao menos podem vir a pertencer) a uma comunidade mundial ${ }^{3}$, sem prejuízo de seus vínculos políticos e culturais locais. Como afirma Ulrich Beck, seria um erro fatal concluir

1 DOLINGER, Jacob. Da dignidade da diferença ao moderno Direito Internacional Privado. In: DOLINGER, Jacob. Direito e Amor. Rio de Janeiro: Renovar, 2009, pp. 135-36.

${ }^{2}$ Vejam-se, dentre outros: APPIAH, Kwame A. Cosmopolitanism: Ethics in a world of strangers. Nova York: W.W. Norton, 2006; BECK, Ulrich. The cosmopolitan vision (trad. para o inglês: Ciaran Cronin). Cambridge: Polity Press, 2006; BENHABIB, Seyla. The rights of others: aliens, residents and citizens. Cambridge: Cambridge University Press, 2004; HELD, David. Cosmopolitanism: ideals and realities. Cambridge, Reino Unido: Polity Press, 2010; POGGE, Thomas W. Global justice. Oxford: Blackwell, 2001; e TAN, Kok-Chor. Justice without borders: cosmopolitanism, nationalism, and patriotism. Cambridge: Cambridge University Press, 2004.

3 Verbete Cosmopolitanism, Stanford Encyclopedia of Philosophy, disponível em: http://plato.stanford.edu/entries/cosmopolitanism, acessado em 05.03.2012. 
que a empatia cosmopolita está substituindo a empatia nacional - ao contrário, elas permeiam, fortalecem, transformam e colorem uma à outra ${ }^{4}$.

$\mathrm{Na}$ sociedade contemporânea, os indivíduos e organizações, ainda que agindo localmente, influenciam ou são afetados por ações de indivíduos do outro lado do globo. Isso ocorre em uma escala sem precedentes, sem que a humanidade tenha desenvolvido, até o momento, respostas políticas e/ou jurídicas suficientes para administrar tais interações, tornando-as mais justas.

A preocupação central do Direito Internacional Privado, desde a escola estatutária italiana (sécs. XIII e XIV), é justamente cuidar, do ponto de vista jurídico, dessas relações que ultrapassam as fronteiras das comunidades locais. Savigny, em meados do séc. XIX, já utilizava como fundamento central de sua obra a noção de uma comunidade jurídica entre os povos, que ultrapassa os limites de cada nação ${ }^{5}$.

Parece-nos, assim, que o Direito Internacional Privado sempre esteve na vanguarda do cosmopolitismo, o que talvez explique o fato de haver sido, por muito tempo, uma disciplina relegada a um papel acessório. Uma matéria incompreendida, porquanto à frente de seu tempo. Nos dias atuais, contudo, o Direito Internacional Privado cresce em importância prática, à medida que as interações privadas internacionais intensificam-se e os modelos jurídicos territorialistas não são mais aptos a fornecer respostas adequadas.

Assim sendo, parece preciso unir a teoria do cosmopolitismo, da maneira como este é enxergado e discutido em outras ciências humanas (destacando-se Filosofia, Ciência Política e Sociologia) à ciência jurídica. O Direito Internacional Privado evidencia-se enquanto um dos receptáculos naturais dessas ideias, uma vez que, há muito, está acostumado a enxergar os seres humanos como membros de uma sociedade mais ampla que suas sociedades locais de origem.

Note-se que Werner Goldschmidt já afirmava, em meados do séc. XX, que o cosmopolitismo jurídico é o único espírito autêntico no qual o Direito Internacional Privado deve se inspirar (opondo-se ao chauvinismo jurídico) ${ }^{6}$. Nesse sentido, a determinação da lei aplicável é um poderoso instrumento do cosmopolitismo, na medida

\footnotetext{
${ }^{4}$ BECK, Ulrich. The cosmopolitan vision (trad. para o inglês: Ciaran Cronin). Cambridge: Polity Press, 2006, p. 6.

${ }^{5}$ SAVIGNY, Friedrich Carl Von. System des Heutigen Römischen Rechts, vol. VIII (trad.: Ciro Mioranza). Ijuí: Editora Unijuí, 2004.

${ }^{6}$ GOLDSCHMIDT, Werner. Sistema y filosofia del Derecho Internacional Privado. Tomo I. Buenos Aires: Ediciones Jurídicas Europa-América, 1952, 2ª ed., pp. 153-154.
} 
em que, ao buscar a aplicação do direito mais próximo ao contexto fático examinado (princípio da proximidade), sem descuidar de alguns princípios universais superiores, busca conciliar valores culturais específicos com a ideia fundamental de que todos os seres humanos possuem status moral idêntico.

É também por respeito a essa igual dignidade que devemos aceitar, enquanto princípio, a aplicação da lei estrangeira, por mais diferente que ela seja da lei do foro, se a situação assim exigir. Do contrário, estaríamos impondo nossos próprios valores unilateralmente, o que equivaleria a nos colocarmos em uma posição de superioridade injustificável em relação aos estrangeiros e suas manifestações culturais.

Desse modo, a presente dissertação tem por objeto analisar o instituto da determinação da lei aplicável no Direito Internacional Privado, sob a ótica de sua teoria geral, utilizando-se para isso do referencial cosmopolita, colhido em outras ciências humanas. No capítulo I, estudar-se-á a teoria do cosmopolitismo nas ciências humanas, buscando-se extrair parâmetros úteis para o estudo adiante empreendido. Em seguida, no capítulo II, analisar-se-ão as implicações da ideia de justiça cosmopolita para a teoria jurídica, em geral, e para o Direito Internacional Privado, em particular. No capítulo III, as principais orientações metodológicas para a determinação da lei aplicável, propostas pela doutrina e acolhidas na jurisprudência - multilateralismo, unilateralismo e materialismo serão examinadas, em perspectivas histórica, comparativa e crítica, especialmente sob o ângulo dos parâmetros cosmopolitas anteriormente discutidos. Já no capítulo IV, proporse-á uma visão cosmopolita do princípio da ordem pública, em atenção especial a desenvolvimentos recentes da teoria que o cerca. Por fim, as principais conclusões extraídas do estudo serão resumidas. 


\section{CAPÍTULO I}

\section{O MARCO TEÓRICO COSMOPOLITA NAS HUMANIDADES}

SUMÁRIO: 1. Percurso histórico do cosmopolitismo. 1.1. Antiguidade. 1.2. O cosmopolitismo kantiano. 2. Cosmopolitismos contemporâneos. 2.1. Considerações gerais. 2.2. A dualidade cosmopolita entre o universalismo e o relativismo. 2.3. Tipos de cosmopolitismo. 2.4. Justiça cosmopolita e imparcialidade. 2.5. Alguns parâmetros cosmopolitas. 2.5.1. Necessidade de avanço do cosmopolitismo empírico-analítico. 2.5.2. Indivíduo como unidade fundamental de consideração moral. 2.5.3. Imparcialidade aberta enquanto postulado teórico. 2.5.4. Busca de equilíbrio entre uma estrutura geral de respeito à diferença e um mínimo universal.

\section{PERCURSO HISTÓRICO DO COSMOPOLITISMO}

\subsection{Antiguidade}

A ideia de cosmopolitismo, com suas diversas variações e nuances, data pelo menos do séc. IV a.C., época em que os filósofos Cínicos criaram o termo para designar o "cidadão do cosmos", expressão esta internamente paradoxal, na medida em que cidadão era aquele que pertencia a determinada comunidade local - polis, à qual devia lealdade, enquanto cosmos referia-se ao universo como um todo, conforme nos noticia Kwame A. Appiah $^{7}$. O primeiro filósofo ocidental a esboçar a visão cosmopolita foi o Cínico Diógenes que, ao ser indagado sobre sua origem, costumava responder: "sou um cidadão do mundo" 8 .

Os Estoicos, no séc. III d.C., levaram adiante essa ideia, ao proporem que a filiação política e o vínculo moral não estavam limitados à polis, mas sim compreendiam o cosmos, segundo a concepção de que todos os seres humanos devem ser considerados enquanto tais

\footnotetext{
${ }^{7}$ APPIAH, Kwame Anthony. Cosmopolitanism - Ethics in a world of strangers. Norton: Nova York, 2007, p. 14.

Diogenes Laertius, VI, 63, apud Verbete Cosmopolitanism, Stanford Encyclopedia of Philosophy, disponível em: http://plato.stanford.edu/entries/cosmopolitanism, acessado em 05.03.2012.
} 
e pertencem, portanto, a uma comunidade universal ${ }^{9}$. Epíteto ensinava que não devemos nos considerar atenienses ou romanos, mas sim cidadãos do universo ${ }^{10}$. Em sentido parecido, Marco Aurélio afirmou: "minha cidade e minha pátria, na medida em que sou Antoninus $^{11}$, são Roma, mas na medida em que sou um homem, são o mundo"12.

Desse modo, para o pensamento estoico, cada um de nós habita duas comunidades: a comunidade do nosso nascimento e a comunidade da razão e da aspiração humanas ${ }^{13}$. Esta última, segundo Sêneca, seria aquela "verdadeiramente grande e verdadeiramente comum, na qual não olhamos para este ou aquele canto, mas medimos os limites da nossa nação por meio do sol" ${ }^{\prime 14}$.

A perspectiva estoica não exige, segundo Martha Nussbaum ${ }^{15}$, o surgimento de um Estado mundial, porém traz importantes implicações para o nosso situar-se no mundo, moral e socialmente. Há compatibilidade com a permanência de formas locais de organização política, mas serve para guiar nosso pensar - político e moral, que deverá considerar o vínculo fundamental e profundo entre todos os seres humanos.

Esse vínculo, na filosofia estoica, baseia-se na razão, possuída por todos e representante de uma parcela do divino dentro de cada um. Nesse sentido, devemos considerar nossas decisões como afetas a questões específicas das pessoas - enquanto seres humanos inseridos em situações concretas particulares, e não nos concentrarmos em questões oriundas de uma identidade local ou nacional que prende e limita nossas $\operatorname{aspirações~morais~}^{16}$.

Isso não significa, para os Estoicos, que devamos nos considerar destituídos de afiliações particulares, mas sim que estamos cercados por vários círculos concêntricos (o primeiro formado por si próprio, o segundo pela família imediata, o terceiro pela família estendida, o quarto pela comunidade local e assim por diante, até toda a humanidade); e

\footnotetext{
${ }^{9}$ Vejam-se: APPIAH, Kwame A. Op. cit., p. 14.; e HELD, David. Cosmopolitanism: Ideals and realities. Cambridge, Reino Unido: Polity Press, 2010, p. 15.

${ }^{10}$ RUSSELL, Bertrand. A history of western philosophy. Nova York: Touchstone, 2007, p. 263.

${ }^{11}$ Antoninus era o sobrenome do imperador.

${ }^{12}$ RUSSELL, Bertrand. Op. cit., p. 266. Tradução livre.

${ }^{13}$ NUSSBAUM, Martha. Kant and Stoic Cosmopolitanism, The Journal of Political Philosophy, v. 5, $\mathrm{n}^{\circ} 1$, 1995 , p. 6.

${ }^{14}$ SENECA. De Otio, 4.1, apud NUSSBAUM, Martha. Op. cit., p. 6.

${ }^{15}$ NUSSBAUM, Martha. Op. cit., pp. 6-8.

${ }^{16}$ NUSSBAUM, Martha. Op. cit., p. 7.
} 
que os vínculos particulares não devem prejudicar aquele que deve fruir da nossa lealdade fundamental: o vínculo da humanidade ${ }^{17}$.

Na lição de Beck, a dualidade cosmopolita dos Estoicos (cosmos vs. polis) não reside na negação de um para a afirmação do outro, mas sim na simultaneidade ${ }^{18}$. Por conseguinte, a cosmopolis seria uma dualidade inclusiva, ainda que hierarquicamente superior às partes que a compõem ${ }^{19}$.

Note-se que a mentalidade cosmopolita encontrou desenvolvimentos e variações posteriores, ao longo da história do pensamento ocidental. É possível mencionar o cosmopolitismo cristão - de viés teológico, que pregava a existência de uma comunidade cristã superior às diferentes comunidades de origem, argumento cuja síntese pode ser encontrada em Efésios, II, 19: “assim, pois, não sois mais estrangeiros ou peregrinos em terras estrangeiras, antes sois concidadãos dos santos e membros da família de Deus $[\ldots]^{, 20}$.

Outro exemplo é a seguinte afirmação do humanista Montaigne (1533-1592), em seus Ensaios: "eu enxergo todos os homens como meus compatriotas, e abraço um polonês como se fora um francês, preferindo o vínculo universal e comum aos vínculos nacionais de toda sorte ${ }^{, 21}$. No entanto, enquanto projeto filosófico mais robusto (e secular), o cosmopolitismo só irá ressurgir com mais força nos trabalhos de Kant, no séc. XVIII ${ }^{22}$.

\footnotetext{
${ }^{17}$ Conforme o pensamento de Hiérocles, citado por NUSSBAUM, Martha. Op. cit., pp. 9-10.

${ }^{18}$ BECK, Ulrich. Op. cit., p. 45.

${ }^{19}$ Idem.

${ }^{20}$ Note-se que orientação religiosa semelhante já estava presente muito antes, nas origens do Judaísmo, cf. Levítico, 19: 33-34 - "Quando um imigrante habitar com vocês no país, não o oprimam. O imigrante será para vocês um concidadão: você o amará como a si mesmo, porque vocês foram imigrantes na terra do Egito".

${ }^{21}$ MONTAIGNE. Essays, III, 9. In: Great Books of Western World. Londres: Britannica, 1952, p. 471. Tradução livre.

22 Jusnaturalistas como Hugo Grócio (1583-1645), Samuel Pufendorf (1632-1694) e Christian Wolff (17141767) vincularam a moralidade universal ao direito; prevendo algumas limitações ao poder dos Estados; mas, apesar disso, suas teorias referem-se primordialmente à relação entre Estados soberanos, e não à relação entre estes e estrangeiros, ou entre os seres humanos no plano internacional (veja-se BROWN, Garrett Wallace. Moving from cosmopolitan legal theory to legal practice: models of cosmopolitan law. Legal Studies, v. 28, $\mathrm{n}^{\mathrm{o}} 3,2008$, p. 434).
} 


\subsection{O cosmopolitismo kantiano}

No terceiro artigo da Paz Perpétua, Kant desenvolve a ideia do direito cosmopolita (Weltbürgerrecht), fundado na hospitalidade - a prerrogativa jurídica (e não meramente filantrópica) de não ser tratado como inimigo ao entrar em outro país ${ }^{23}$. Assim, o teórico deixa claro que a hospitalidade não deve ser compreendida como uma virtude de sociabilidade, a exemplo da gentileza ou da generosidade, mas sim como um direito pertencente a todos os seres humanos ${ }^{24}$.

Notando a natureza esférica do planeta e a inevitabilidade do contato entre os seres humanos, bem como a existência de uma verdadeira comunidade mundial (seja ela ampla ou estreita), Kant defende que a violação de direitos em uma parte do globo é sentida em todos os lugares ${ }^{25}$. Assim, o direito cosmopolita não seria uma ideia exagerada, mas um acréscimo necessário aos direitos nacional e internacional ${ }^{26}$.

O jus cosmopoliticum kantiano importa o direito de cada ser humano, enquanto cidadão do mundo, buscar a comunhão com todos os outros e, para esse propósito, visitar todas as regiões do planeta ${ }^{27}$. Como ensina Celso Lafer, Kant acrescenta aos dois níveis tradicionais do jurídico (direito interno e Direito Internacional Público) um novo: o direito cosmopolita, que diz respeito aos seres humanos e aos Estados em suas relações exteriores, enquanto agentes interdependentes de uma comunidade política universal ${ }^{28}$.

$\mathrm{Na}$ interpretação de Held, o direito cosmopolita de Kant significa a possibilidade de se apresentar e ser ouvido em todas as comunidade políticas, um direito de dialogar sem que haja restrições ou delimitações artificiais ${ }^{29}$. Discordamos ligeiramente de Held, apenas

\footnotetext{
${ }^{23}$ KANT, Immanuel. Perpetual peace and other essays (trad. para o inglês: Ted Humphrey). Indianapolis: Hackett Publishing, 1983 (edição original de 1795), p. 118.

${ }^{24}$ BENHABIB, Seyla. The philosophical foundations of cosmopolitan norms. In: POST, Robert (ed.). Another cosmopolitanism - The Berkeley Tanner lectures. Nova York: Oxford University Press, 2006, p. 22. Veja-se, também: TORRES, Ricardo Lobo. A afirmação do direito cosmopolita. In: DIREITO, Carlos Alberto Menezes; TRINDADE, Antonio Augusto Cançado; PEREIRA, Antônio Celso Alves. Novas perspectivas do Direito Internacional Contemporâneo - Estudos em homenagem ao Professor Celso D. de Albuquerque Mello. Rio de Janeiro: Renovar, 2008, p. 922.

${ }^{25}$ KANT, Immanuel. Perpetual peace and other essays (trad. para o inglês: Ted Humphrey). Indianapolis: Hackett Publishing, 1983 (edição original de 1795), pp. 118-119.

${ }^{26}$ KANT, Immanuel. Perpetual peace and other essays (trad.: Ted Humphrey). Indianapolis: Hackett Publishing, 1983 (edição original de 1795), p. 119.

${ }^{27}$ KANT, Imannuel. The science of right, Great Books of Western World. Londres: Britannica, 1952, p. 456.

${ }^{28}$ LAFER, Celso. Prefácio à obra “A Era dos Direitos", de Norberto Bobbio. Rio de Janeiro: Elsevier, 2004, p. 14.

${ }^{29}$ HELD, David. Op. cit., p. 42.
} 
no sentido de que, no que se refere a Kant, esse diálogo livre não deve ser compreendido como atinente à participação política, na medida em que o filósofo deixa claro que o cosmopolitismo, segundo sua concepção, é um princípio jurídico - uma espécie de direito subjetivo.

Não obstante, o direito à hospitalidade, para Kant, não é ilimitado. Em primeiro lugar, a hospitalidade abrange o direito de visita, mas o direito de permanência resta condicionado à existência de uma concessão especial ${ }^{30}$. A segunda limitação deriva da própria caracterização jurídica da hospitalidade - conforme observa Derrida, a construção da hospitalidade kantiana enquanto conceito jurídico torna-a dependente do Estado, controlada pelo direito e pelo aparato deste, em que pese o fato de constituir um enorme avanço, sobretudo se considerarmos a época em que Kant escreveu ${ }^{31}$.

Devemos observar que, sendo a hospitalidade um princípio (e não uma regra), sua compreensão não deve se limitar ao direito de visita, devendo antes ser interpretada como uma ideia que informa uma variedade de normas distintas ${ }^{32}$. Nesse sentido, o jus cosmopoliticum de Kant deve ser visto como um princípio aplicável a um feixe de questões que possuem natureza distinta daquelas encontradas nos direitos domésticos e no Direito Internacional Público tradicional. Tais questões dizem respeito à vida dos seres humanos no plano internacional e ao tratamento que os Estados devem dispensar aos estrangeiros que aportam em suas terras.

Com efeito, atualmente o dever de hospitalidade kantiano assume (com nuances variadas conforme o autor) contornos mais amplos. Nesse sentido, Seyla Benhabib entende que a hospitalidade kantiana deve abarcar todas as pretensões de direitos humanos que são transfronteiriças por natureza ${ }^{33}$. Já Jeremy Waldron associa a ideia de Kant à miríade de processos por meio dos quais seres humanos, ao redor do mundo, entram em contato direto ou indireto uns com os outros - viagens, comércio etc ${ }^{34}$.

Kant anteviu um mundo em que todos os seres humanos viveriam em uma condição de associação jurídica, mas este mundo não prescindiria dos Estados - porquanto o cidadão

\footnotetext{
${ }^{30}$ KANT, Immanuel. Perpetual peace and other essays (trad.: Ted Humphrey). Indianapolis: Hackett Publishing, 1983 (edição original de 1795), p. 118.

31 DERRIDA, Jacques. On cosmopolitanism and forgiveness (trad.: Mark Dooley e Michael Hughes). Londres e Nova York: Routledge, 2005 (edição original de 1997), pp. 21-22.

${ }^{32}$ WALDRON, Jeremy. Cosmopolitan norms. In: POST, Robert (ed.). Another Cosmopolitanism, The Berkeley Tanner Lectures. Nova York: Oxford University Press, 2006, p. 88.

${ }^{33}$ BENHABIB, Seyla. The philosophical foundations of cosmopolitan norms. In: POST, Robert (ed.). Another Cosmopolitanism, The Berkeley Tanner Lectures. Nova York: Oxford University Press, 2006, p. 31.

${ }^{34}$ WALDRON, Jeremy. Cosmopolitan norms. In: POST, Robert (ed.). Another Cosmopolitanism, The Berkeley Tanner Lectures. Nova York: Oxford University Press, 2006, p. 90.
} 
cosmopolita necessita, em sua visão, de um Estado, sem o qual não seria nem mesmo um cidadão ${ }^{35}$.

O filósofo prussiano pode ser considerado o grande teórico do cosmopolitismo moderno, por haver retomado a ideia dos Estoicos de que há uma comunidade universal do gênero humano a gerar obrigações para todos, e desenvolvido tal concepção no sentido de que tais obrigações - o dever de hospitalidade, em sentido lato - são vínculos jurídicos, e não meramente morais ou filantrópicos.

Sobretudo nas últimas duas décadas, autores diversos retomaram a discussão do marco teórico cosmopolita, certamente influenciados pela internacionalização da vida em seus mais diversos aspectos, que ganhou grande impulso com a revolução das tecnologias da informação e comunicação, com a intensificação dos fluxos migratórios e com a descentralização das cadeias produtivas, dentre outros fatores. Essa discussão, atual e inacabada, será objeto do próximo item.

\section{COSMOPOLITISMOS CONTEMPORÂNEOS}

\subsection{Considerações gerais}

Não é possível falar de um cosmopolitismo único, enquanto proposta teórica, na medida em que há variações importantes conforme o autor. Como afirma Appiah, ao tratar da tensão que pode surgir quando dois valores cosmopolitas se chocam - consideração universal e respeito à diferença legítima, há a percepção de que "cosmopolitismo" não é exatamente o nome da solução, mas sim do desafio ${ }^{36}$.

Para os propósitos deste trabalho, entenda-se esse desafio como a coleta e reflexão sobre elementos teóricos diversos encontrados em autores cosmopolitas, aptos a lançar luzes sobre o instituto da determinação da lei aplicável no Direito Internacional Privado. O corte epistemológico que será empreendido é apenas uma das alternativas possíveis. Similarmente, os valores que serão defendidos não estão imunes a críticas a partir de pontos de vista diferentes.

${ }^{35}$ BENHABIB, Seyla. The philosophical foundations of cosmopolitan norms. In: POST, Robert (ed.). Another Cosmopolitanism, The Berkeley Tanner Lectures. Nova York: Oxford University Press, 2006, p. 24.

${ }^{36}$ APPIAH, Kwame A. Op. cit., p. 15. 
De certo modo, essas ressalvas decorrem da própria lógica cosmopolita que defenderemos, avessa ao monopólio da verdade, aberta ao diálogo e respeitadora das diferenças legítimas. Em verdade, talvez o único pensamento compartilhado por todos os cosmopolitas seja o de que nenhuma lealdade local pode nos levar a esquecer de que cada ser humano possui responsabilidades em relação a todos os outros ${ }^{37}$.

Held afirma, por exemplo, que o cosmopolitismo impõe a noção de que o indivíduo é a unidade fundamental de consideração moral, e não os Estados ou qualquer outra forma de organização humana - é o princípio do individualismo igualitário no plano internacional $^{38}$. Essa igualdade, para o autor, conduz ao segundo princípio - o do reconhecimento recíproco, no sentido de que qualquer decisão deve se basear na força do melhor argumento, e não em elementos intrusos não discursivos. Por fim, o individualismo igualitário e o reconhecimento recíproco requerem o tratamento imparcial das demandas de qualquer indivíduo, tratamento este baseado em princípios que ninguém poderia razoavelmente rejeitar - é o terceiro princípio reconhecido por Held, o do raciocínio imparcial $^{39}$.

Como afirma Hill, imparcialidade significa que nenhum indivíduo particular, grupo, ou país possui status especial - declarar "eu gosto disso", "isso serve ao meu país" ou frases similares não é decisivo do ponto de vista moral; ao revés, são válidos apenas princípios defensáveis por qualquer um que enxergue a matéria de uma perspectiva neutra $^{40}$. Essa exigência de imparcialidade será melhor explorada no item I.2.4 infra, ao tratarmos da ideia de justiça cosmopolita.

A expansão e densificação do cosmopolitismo são, na realidade, uma necessidade cada vez mais premente, conforme o mundo vai, exponencialmente, tornando-se mais interdependente. Nesse sentido, sobre o significado e a importância da perspectiva cosmopolita, Beck afirma:

\footnotetext{
${ }^{37}$ Idem.

${ }^{38}$ HELD, David. Op. cit., p. 44.

${ }^{39} \mathrm{O}$ raciocínio imparcial remete à figura do espectador imparcial, proposta por Adam Smith em sua Teoria dos Sentimentos Morais (1759): “We can never survey our own sentiments and motives, we can never form any judgment concerning them, unless we remove ourselves, as it were, from our own natural station, and endeavour to view them as at a certain distance from us. But we can do this in no other way than by endeavouring to view them with the eyes of other people, or as other people are likely to view them." (SMITH, Adam. The theory of moral sentiments, Nova York: Penguin Classics, 2009, III.i.2, p. 133). Vejase, também, o item I.2.4, infra.

${ }^{40}$ HILL, Thomas. The importance of autonomy. In: KITTAY, E.; MEYERS, D. (eds.), Women and Moral Theory. Towata: Rowman and Allanheld, p. 138; apud HELD, David. Op. cit., pp. 46-47.
} 
"Então, o que significa a perspectiva cosmopolita? Ela não anuncia os primeiros raios de amor fraternal e universal entre os povos, ou o alvorecer da república mundial, ou uma visão global errática, ou ainda xenofilia compulsória. Tampouco o cosmopolitismo é algo que visa substituir o nacionalismo e o localismo, pela boa razão de que as ideias de direitos humanos e de democracia necessitam de uma base nacional. Na verdade, o cosmopolitismo significa que, em um mundo de crises e perigos globais produzidos pela civilização, as antigas diferenças entre o externo e o interno, o nacional e o internacional, nós e eles, perdem sua validade e um novo realismo cosmopolita faz-se necessário para sobreviver, ${ }^{\circ 1}$.

Note-se que o cosmopolitismo comporta duas ideias essenciais: (i) a de que há obrigações entre os seres humanos além daquelas particulares - derivadas da família, dos grupos, da nacionalidade comum etc - i.e., há obrigações universais; e (ii) a de que, apesar disso, as diferenças culturais são valiosas, havendo muito a aprender com elas - i.e., não se quer promover um modo de vida único ${ }^{42}$. Essas duas noções básicas, às vezes, entram em conflito (obrigações universais $\mathrm{x}$ direito à diferença), tornando-se necessário analisar $\mathrm{o}$ marco cosmopolita em face do universalismo e do relativismo cultural, discussão que será travada no próximo item.

\subsection{A dualidade cosmopolita entre o universalismo e o relativismo}

Como já afirmado, o cosmopolitismo nasceu, na Grécia Antiga, enquanto dualidade (cosmos - universo, e polis - comunidade política circunscrita). Desse modo, há uma tensão interna ao próprio conceito, entre a universalidade e a particularidade dos valores.

Nesse contexto, aponte-se que tanto o universalismo quanto o relativismo cultural trazem consigo riscos inerentes. $\mathrm{O}$ universalismo repousa sobre a ideia de que os seres humanos são iguais em princípio, mas pode nos levar a negligenciar a curiosidade e o respeito por aquilo que nos torna diferentes, conduzindo à autonegação desse respeito universal $^{43}$. Similarmente, o relativismo cultural almeja reconhecer a diferença, mas se

${ }^{41}$ BECK, Ulrich. Cosmopolitan vision. Cambridge: Polity Press, 2006, pp. 13-14. Tradução livre.

${ }^{42}$ APPIAH, Kwame A. Op. cit., p. 15.

${ }^{43}$ Veja-se: BECK, Ulrich. Op. cit., p. 49. 
levado ao extremo equivale a uma incomensurabilidade de perspectivas - i.e., a uma ignorância preestabelecida ${ }^{44}$.

Ao ser desvirtuado, o universalismo torna-se um universalismo hegemônico. Pelo prisma hegemônico, busca-se ultrapassar ou excluir as diferenças culturais: a voz é concedida ao outro somente enquanto voz de autoconfirmação - a visão alheia só importa quando reproduz a minha própria, redundando em um monólogo disfarçado ${ }^{45}$. Há, ainda, o risco de o establishment proclamar seus próprios valores específicos, particulares, como se universais fossem. Por último, não se deve negligenciar o risco de transfiguração e supressão do indivíduo $^{46}$, na medida em que o ser humano universal é apenas uma abstração. Toda vida é concreta e particular.

Uma certa dose de relativismo é o antídoto contra a soberba universalista. Ao contextualizarmos as práticas de culturas específicas, e as respeitarmos enquanto manifestações legítimas, valorizamos o direito à diferença. As teorias relativistas suspeitam de que muito do que consideramos certo ou errado seja uma questão de costume local e, assim, para seus adeptos, falar em verdades morais objetivas seria um erro conceitual ${ }^{47}$.

No entanto, um relativismo extremo importa a rejeição de qualquer troca de perspectivas $^{48}$, na medida em que tudo é permitido sob a rubrica da tradição. Um relativismo absoluto implica que, ao final de qualquer discussão, ambos os interlocutores possam ser considerados corretos, a partir de suas próprias perspectivas. Mas se não é possível aprender uns com os outros sobre o que é correto, para que haver qualquer diálogo ${ }^{49}$

Outro problema é que a incomensurabilidade leva ao conformismo - se as coisas não podem ser avaliadas de modo neutro, precisamos aceitá-las do modo como são. Além disso, aceitar tradições que impliquem graves violações de direitos humanos equivaleria a desrespeitar suas vítimas ${ }^{50}$ - o respeito à cultura se sobreporia, de modo inaceitável, ao respeito ao indivíduo. Há tradições que não nos são indiferentes do ponto de vista moral -

\footnotetext{
${ }^{44}$ BECK, Ulrich. Op. cit., p. 49.

${ }^{45}$ Veja-se BECK, Ulrich. Op. cit., p. 51.

${ }^{46}$ BECK, Ulrich. Op. cit., pp. 52-53.

${ }^{47}$ APPIAH, Kwame A. Op. cit., p. 17.

${ }^{48}$ BECK, Ulrich. Op. cit., p. 54

${ }^{49}$ APPIAH, Kwame A. Op. cit., pp. 30-31.

${ }^{50}$ BECK, Ulrich. Op. cit., p. 53.
} 
são simplesmente erradas ${ }^{51}$ e não podem ser aceitas. Em resumo, o relativismo pode levar à indiferença e à naturalização de injustiças. Por conseguinte, o relativismo, assim como o universalismo, também traz consigo riscos importantes.

É preciso ser tolerante em relação à verdade do outro. Nesse ponto, é útil a lição de Bobbio $^{52}$, que aponta diversas razões para a tolerância. Em primeiro lugar, de um ponto de vista histórico e utilitarista, a perseguição, longe de enfraquecer, tende a fortalecer determinada verdade alheia que o perseguidor pretende modificar. Em segundo lugar, qualquer método universalmente válido deve se basear na persuasão, e não na coerção - é preciso considerar os próprios interesses à luz dos interesses dos outros. Além disso, há um fundamento ético - o respeito à pessoa alheia. Por fim, há o argumento filosófico de que a verdade só pode ser alcançada por meio de um confronto de verdades parciais e, para tanto, a tolerância é um pré-requisito. No entanto, Bobbio também prevê limites para a tolerância, ao afirmar que esta pode ter um sentido negativo - quando se é condescendente com o mal, por exemplo. Há, portanto, uma espécie de zona cinzenta. Consequentemente, para o grande teórico italiano, a intolerância não deve ser tolerada - eis o limite da ideia de tolerância.

O dilema entre o universalismo e o relativismo não pode ser resolvido pela escolha de uma das duas perspectivas. Como afirma Beck, um cosmopolitismo realista deve ser concebido e praticado de maneira inclusiva: abrange o universalismo e a contextualização, o nacional e o transnacional ${ }^{53}$. Assim, o cosmopolitismo baseia-se na ideia de tolerância, mas há limites para a tolerância cosmopolita - algumas vezes precisamos intervir. Quando os fatos violam nossos princípios fundamentais de modo profundo, é preciso cessar o diálogo (o genocídio é a hipótese incontroversa) ${ }^{54}$.

Dessa forma, há a pressuposição de um mínimo universal (composto por normas cuja violação seria evidentemente incompatível com a ideia de tolerância cosmopolita $)^{55}$, porém se reconhece, de um modo geral, o valor da diferença. Como afirma Appiah, há alguns valores que são (e devem ser) universais, assim como há muitos valores que são (e

\footnotetext{
${ }^{51}$ APPIAH, Kwame A. Op. cit., p. 10. O autor cita como exemplo a punição ao adultério. A resposta mais apropriada contra o adultério não é submeter a acusada a uma corte religiosa e, caso condenada, organizar uma multidão para apedrejá-la (muitas pessoas, inclusive uma grande parcela dos muçulmanos, rejeitam tal prática). Contudo, ainda há muitos que acreditam que isso é o que a sharia exige.

${ }_{52}$ BOBBIO, Norberto. A era dos direitos. Rio de Janeiro: Elsevier, 2004, pp. 186-199.

${ }^{53}$ BECK, Ulrich. Op. cit., p. 49.

${ }^{54}$ APPIAH, Kwame A. Op. cit., p. 21.

${ }^{55}$ BECK, Ulrich. Op. cit., p. 49.
} 
devem ser) locais, não havendo muita esperança quanto a um consenso final sobre como hierarquizar ou ordenar tais valores ${ }^{56}$.

O autor toma emprestado, de um poema antigo, a metáfora do espelho despedaçado ${ }^{57}$. Cada pedaço do espelho reflete apenas uma pequena parte de uma verdade complexa, vista por determinado ângulo - e o maior erro é achar que o nosso pedaço do espelho é capaz de refletir o todo ${ }^{58}$.

O cosmopolitismo supõe que todas as culturas (e pessoas) possuem um vocabulário de valores comum o suficiente para iniciar um diálogo; mas não supõe, como faz o universalismo utópico, que todos entrariam em acordo caso compartilhassem o mesmo vocabulário $^{59}$. O cosmopolitismo acredita no pluralismo (ideia de que diferentes pessoas e diferentes sociedades incorporarão valores diferentes) e na falibilidade (ideia de que nosso conhecimento é sempre imperfeito e provisório, sujeito a revisões) ${ }^{60}$.

Assim, como ensina Held, a elaboração de princípios cosmopolitas não busca um entendimento universal sobre um amplo espectro de assuntos, mas se trata de um exercício mais modesto de reflexão sobre o status moral das pessoas e sua representação, bem como sobre as deliberações coletivas que lhes dizem respeito ${ }^{61}$. Há a premissa de que normas básicas de comunicação, diálogo e resolução de disputas são não apenas desejáveis como essenciais, precisamente porque as pessoas possuem status moral idêntico, ao passo que seus pontos de vista podem conflitar ${ }^{62}$.

Do exposto se extrai que a discussão "universalismo x relativismo" é um debate eterno entre alternativas falsas. Como defende Boaventura de Sousa Santos, devemos, contra o universalismo, propor diálogos interculturais sobre preocupações convergentes; e, contra o relativismo, propor critérios que possam distinguir uma cultura progressista de uma cultura conservadora no que se refere aos direitos humanos ${ }^{63}$.

\footnotetext{
${ }^{56}$ APPIAH, Kwame A. Op. cit., p. 21.

${ }^{57}$ APPIAH, Kwame A. Op. cit., p. 8.

${ }^{58}$ Idem.

${ }^{59}$ Veja-se APPIAH, Kwame A. Op. cit., p. 57.

${ }^{60}$ APPIAH, Kwame A. Op. cit., p. 144.

${ }^{61}$ HELD, David. Op. cit., p. 76.

${ }^{62}$ HELD, David, Op. cit., pp. 76-77.

63 SANTOS, Boaventura de Sousa. Introdução: as tensões da modernidade ocidental. In: SANTOS, Boaventura de Sousa (org.). Reconhecer para libertar: os caminhos do cosmopolitismo multicultural. Rio de Janeiro: Civilização Brasileira, 2003, p. 441.
} 
Nesse ponto, é extremamente útil a lição de Beck, para quem um cosmopolitismo realista não deve ser entendido como oposto ao universalismo ou ao relativismo, mas sim como uma síntese de ambas as noções - desse modo, universalismo e relativismo pressupõem, corrigem, limitam e dão suporte um ao outro ${ }^{64}$. Um cosmopolitismo viável deve equilibrar o respeito pela diferença com o respeito pelos seres humanos de carne e osso $^{65}$. Em especial, o cosmopolitismo deve evitar dois perigos: o de um universalismo totalitário, mas também o de um relativismo indiferente, acrítico.

\subsection{Tipos de cosmopolitismo}

Os cosmopolitismos podem ser classificados em diferentes categorias. Em primeiro lugar, é possível falar de um cosmopolitismo filosófico ou normativo, que prega a harmonia além das fronteiras nacionais e culturais; em contraste com um cosmopolitismo empíricoanalítico, que possui como objeto o exame do aprofundamento da interdependência transfronteiriça, libertando-se das categorias nacionais que tradicionalmente prevalecem nas ciências sociais ${ }^{66}$.

Outra diferenciação possível dá-se entre a cosmopolitização da realidade e o cosmopolitismo institucionalizado ${ }^{67}$. A primeira traduz um cosmopolitismo inconsciente e passivo, que molda a realidade enquanto efeito secundário do comércio e das ameaças globais (mudanças climáticas, terrorismo, crises financeiras etc) - a vida, o corpo e a existência individuais passam a fazer parte de um mundo diferente, de culturas, histórias e religiões estrangeiras, de interdependências globais, sem que necessariamente apreendamos isso de maneira consciente ${ }^{68}$. Esse "cosmopolitismo banal", na expressão de Beck, manifesta-se concretamente através do fato de que as diferenciações entre "nós" e “eles” tornam-se confusas - seja em Dubai, Nova York ou São Paulo, as grandes cidades tornam-se locais de encontros e misturas, ou ainda de coexistência anônima de vários mundos possíveis, bem como de perigos globais diversos ${ }^{69}$.

\footnotetext{
${ }^{64}$ BECK, Ulrich. Op. cit., p. 57.

${ }^{65}$ APPIAH, Kwame A. Op. cit., p. 113.

${ }^{66}$ BECK, Ulrich. Op. cit., pp. 17-18.

${ }^{67}$ Cf. BECK, Ulrich. Op. cit., p. 17-27.

${ }^{68}$ BECK, Ulrich. Op. cit., p. 19.

${ }^{69}$ Cf. BECK, Ulrich. Op. cit., p. 10. Os exemplos de cidades foram modificados por este autor.
} 
O cosmopolitismo institucionalizado, por outro lado, diz respeito ao surgimento de certos regimes globais preocupados com a mediação e resolução de conflitos transnacionais. A criação de tais regimes pode ser impulsionada pela conceptualização e reconhecimento dessas ameaças em escala global, levando a um espaço de responsabilidade e representação que ultrapassa as fronteiras políticas tradicionais (é possível, porém não inevitável, que assim seja - visto que a negociação para a criação de tais instituições é extremamente problemática) ${ }^{70}$.

Observe-se que a evidente cosmopolitização da vida torna imprescindível o avanço do cosmopolitismo empírico-analítico, sob pena de nos referirmos a uma sociedade que já não existe mais, e através de conceitos e cortes epistemológicos que já não fazem mais muito sentido. Nesse contexto, transcrevemos o alerta de Beck-Gernsheim no sentido de que

\footnotetext{
"todos os métodos de análise que trabalham com conceitos estatísticos como 'estrangeiro' e 'nativo' estão despreparados para as realidades da vida em um mundo que se torna crescentemente transnacional e envolve vínculos plurais que transcendem as fronteiras dos países e da nacionalidade" ${ }^{, 71}$.
}

O cosmopolitismo pode, ainda, ser dividido em duas perspectivas: a vertical e a horizontal $^{72}$. O cosmopolitismo vertical é aquele cuja implementação é concebida de cima para baixo - com a ideia de um poder central que prevaleça sobre os Estados nacionais. Já o cosmopolitismo horizontal importa a interação e interpenetração de Estados e sociedades nacionais para além da distinção entre o nacional e o internacional - os Estados e as soberanias não são supérfluos, mas devem ser redefinidos e estendidos na direção cosmopolita.

A ideia de tratamento de todos os seres humanos com iguais consideração e respeito não implica a necessidade de um Estado mundial - instituições destinadas a

\footnotetext{
${ }^{70}$ Veja-se BECK, Ulrich. Op. cit., p. 23.

71 BECK-GERNSHEIM, E. Wir und die Anderen. Frankfurt am Main: Suhrkamp, 2004, p. 106, apud BECK, Ulrich. Op. cit., p. 26. Tradução livre. Ulrich Beck defende a necessidade de uma teoria crítica cosmopolita, que envolveria duas etapas: (i) a crítica da perspectiva nacional; e (ii) reflexões preliminares sobre a gramática cosmopolita da realidade político-social (cf. BECK, Ulrich. Op. cit., p. 24).

${ }^{72}$ Cf. BECK, Ulrich. Op. cit., p. 162.
} 
cumprir as obrigações relacionadas à justiça podem ser organizadas localmente, de maneira pluralística $^{73}$. Aqui, é útil recordar do alerta de Kant, no sentido de que um poder mundial superior pode se degenerar em um despotismo mundial e, sendo assim, a existência de Estados separados, independentes, seria uma estrutura preferível ${ }^{74}$. Se, além de envolver negociações extremamente difíceis, a governança global por meio de instituições pode se transformar em tirania global, mostra-se mais realista e prudente, ao menos por enquanto, a aplicação dos princípios cosmopolitas por uma pluralidade de agentes, como propõe Onora $\mathrm{O}^{\prime} \mathrm{Neill}^{75}$. Aqui, não se nega a importância e a utilidade de instituições globais, a exemplo da Organização das Nações Unidas (ONU), mas tão somente se afirma que tais regimes não podem prescindir dos Estados.

Note-se que, como afirma Habermas, na medida em que os governos nacionais precisam assegurar o apoio político de suas populações locais, o desafio de incorporar cada Estado à estrutura cooperativa de uma comunidade cosmopolita deve ser percebido também como parte da própria agenda política doméstica do Estado ${ }^{76}$. Sem uma reforma da estrutura (e, sobretudo, da mentalidade) doméstica, portanto, não parece haver saída.

Dessa forma, não se preconiza a substituição dos ordenamentos nacionais por uma ordem universal, mas sim a emergência de uma nova ordem inspirada na interdependência entre o local, o nacional e o global ${ }^{77}$. Os Estados precisam, nesse contexto, articular-se com uma estrutura cosmopolita abrangente, bem como reorganizar-se dentro dela - fala-se em um cosmopolitismo de camadas $^{78}$.

Observe-se que, a despeito de incontáveis imperfeições, os Estados ainda constituem os agentes de justiça mais bem equipados do mundo contemporâneo. Não é preciso (tampouco viável ou recomendável) acabar com os Estados - o que se deve buscar é a reforma destes na direção cosmopolita. Trata-se de desenvolver o cosmopolitismo horizontal, antes cultural e hermenêutico que institucional e burocrático.

\footnotetext{
${ }^{73}$ GOSEPATH, Stefan. The global scope of justice. In: POGGE, Thomas W. (org.). Global justice. Malden, MA: Blackwell Publishing, 2001, p. 162.

${ }^{74}$ KANT, Immanuel. Perpetual peace and other essays (trad.: Ted Humphrey). Indianapolis: Hackett Publishing, 1983 (edição original de 1795), pp. 124-125. Veja-se, no mesmo sentido: RAWLS, John. The Law of Peoples, Critical Inquiry, Autumm 1993, p. 46.

${ }^{75}$ O’NEILL, Onora. Agents of justice. In: POGGE, Thomas W. (org.). Global justice. Malden, MA: Blackwell Publishing, 2001, pp. 188-189.

${ }^{76}$ HABERMAS, Jürgen. The postnational constellation: political essays (traduzido do original em alemão, de 1998, por Max Pensky). Cambridge, MA: The MIT Press, 2001, p. 55.

${ }^{77}$ BENHABIB, Seyla. Democratic iterations: the local, the national and the global. In: POST, Robert (ed.). Another Cosmopolitanism, the Berkeley Tanner Lectures. Nova York: Oxford University Press, 2006, p. 74.

${ }^{78}$ HELD, David. Op. cit., pp. 69-105.
} 
No que se refere às obrigações morais, o cosmopolitismo pode ser extremo ou moderado $^{79}$. Para os extremistas, todas as obrigações morais devem ser justificadas com base em princípios ou objetivos cosmopolitas; ao passo que o cosmopolitismo moderado reconhece a independência normativa de algumas obrigações morais especiais. A versão moderada aceita que há aspectos de determinadas relações pessoais, incluindo a nacionalidade comum, que não podem ser reduzidos a obrigações gerais de justiça - mas isso não significa que tais relações não devam ser limitadas por princípios de justiça ${ }^{80}$.

Com efeito, a fonte ou justificação de determinadas preferências, de um lado; e seus contornos (limites), de outro, são problemas de naturezas distintas. Se assim é no plano estritamente moral, tal distinção fica ainda mais clara no plano jurídico: o fato de haver relações especiais entre determinadas pessoas não exime o cosmopolitismo jurídico da imparcialidade. É certo que as relações familiares ou de amizade de um juiz não possuem valor meramente instrumental em relação à sociedade, porém seria um absurdo admitir que o magistrado se valha do poder no qual está investido para beneficiar os seus. Raciocínio análogo pode ser feito no que se refere à nacionalidade - o sistema jurídico não deve ser um meio de beneficiar compatriotas.

\subsection{Justiça cosmopolita e imparcialidade}

A justiça é uma ideia complexa, debatida há milênios por filósofos dos mais variados matizes, fugindo do escopo do presente estudo a discussão detalhada e infindável que a mesma suscita. No entanto, algumas considerações podem ser feitas, de modo a explorar certas exigências da justiça, quando especificamente considerada no âmbito internacional.

Aristóteles declarou, na Ética a Nicômaco, que somente a justiça, dentre todas as virtudes, é o bem de outro, pois se relaciona com o próximo, ao determinar que se faça o que lhe é vantajoso. Nesse sentido, para Aristóteles, o melhor dos homens não é aquele que exerce sua virtude em relação a si mesmo, mas sim em relação a outrem, pois esta é que é a

\footnotetext{
${ }^{79}$ SCHEFFLER, Samuel. Boundaries and allegiances. Nova York: Oxford University Press, 2001, pp. 115119.

${ }^{80}$ Nesse sentido: TAN, Kok-Chor. Justice without borders: cosmopolitanism, nationalism and patriotism. Nova York: Cambridge University Press, 2004, pp. 149-150.
} 
tarefa difícil ${ }^{81}$. Já Ulpiano proclamou, no Digesto, que a justiça é a vontade constante e perpétua de dar a cada um aquilo que lhe pertence (iustitia est constans et perpetua voluntas ius suum cuique tribuendi $)^{82}$.

Outro autor fundamental é Adam Smith, que na Teoria dos Sentimentos Morais desenvolveu a imagem do espectador imparcial, uma espécie de consciência interna, possuída por cada ser humano, que lhe permite corrigir a natural inclinação à defesa dos próprios interesses em detrimento dos interesses dos demais. Segundo Smith, não podemos equilibrar nossos interesses com os de outrem sem que antes nos coloquemos em uma posição intermediária - que não é a nossa posição, tampouco a posição do outro; mas consiste na posição imaginária de uma terceira pessoa sem conexão com qualquer dos dois, capaz de julgar com imparcialidade ${ }^{83}$. Desse modo, seria possível obedecer a um senso de justiça e adequação, apto a corrigir a natural iniquidade dos nossos sentimentos ${ }^{84}$.

Permitimo-nos transcrever o seguinte trecho da clássica obra de Smith, no sentido de elucidar a ideia e função do espectador imparcial:

\begin{abstract}
"Não é o poder sutil da humanidade, não é a fraca faísca de benevolência que a Natureza acendeu no coração humano, que é capaz de contrabalançar os fortes impulsos do amor-próprio. Trata-se de um poder mais forte, um motivo mais forçoso, que se afirma nessas ocasiões. É razão, princípio, consciência, o habitante do peito, o homem interno, o grande juiz e árbitro da nossa conduta. É ele que, sempre que estamos prestes a agir de modo a afetar a felicidade dos outros, nos recorda, com uma voz capaz de assombrar as nossas paixões mais ousadas, de que somos apenas mais um na multidão, e de modo algum melhor que qualquer outro membro dela; e que quando preferimos a nós mesmos, vergonhosa e cegamente, aos outros, tornamo-nos dignos de ressentimento, repugnância e execração. É apenas com ele que aprendemos a nossa real pequeneza, e de qualquer coisa que nos diga respeito, e as naturais deturpações do amor-próprio podem ser corrigidas apenas pelo olhar do espectador imparcial”, ${ }^{85}$.
\end{abstract}

\footnotetext{
${ }^{81}$ ARISTÓTELES. Ética a Nicômaco (trad.: Pietro Nassetti), Livro V, 1130a. São Paulo: Martin Claret, 2004, pp. 105-106.

${ }^{82}$ Digesto, 1.1.10.1.

${ }^{83}$ SMITH, Adam. Op. cit., p. 157.

${ }^{84}$ SMITH, Adam. Op. cit., p. 158.

${ }^{85}$ SMITH, Adam. Op. cit., p. 159. Tradução livre.
} 
Intimamente ligada a essa busca interna por imparcialidade está outro aspecto da construção teórica de Smith: o de que é preciso considerar as perspectivas alheias, de modo a criticar nossos próprios sentimentos e motivos com um certo distanciamento de nós mesmos. Trata-se de "tentar vê-los com os olhos de outras pessoas, ou como outras pessoas provavelmente os enxergarão" ${ }^{\prime 6}$. Conforme observa Amartya Sen, Adam Smith preocupa-se em ampliar o debate, com vistas a evitar um provincianismo (parochialism) local de valores - sendo metodologicamente importante invocar uma variedade de pontos de vista baseados em experiências diversas ${ }^{87}$.

Mais recentemente, em sua obra fundamental, John Rawls ${ }^{88}$ desenvolveu uma concepção contratualista de justiça, no sentido de que esta seria composta pelos princípios que seres humanos livres e racionais escolheriam, de comum acordo, para regê-los, caso se encontrassem em uma posição original de absoluta igualdade. Essa posição original seria marcada pelo fato de que ninguém saberia, de antemão, sua classe ou status social, tampouco seus dotes naturais, habilidades, inteligência, força etc. Similarmente, ninguém teria conhecimento acerca de suas concepções sobre o bem ou de suas tendências psicológicas específicas. Em linhas gerais, essa é a ideia do véu da ignorância, que tornaria possível a escolha unânime de uma concepção particular de justiça. $\mathrm{O}$ autor propôs, ainda, que a ideia de posição original deve ser interpretada de modo que qualquer um possa, a qualquer tempo, adotar sua perspectiva ${ }^{89}$.

A construção de Rawls possui como característica central a necessidade de evitarmos avaliações tendenciosas por influência dos nossos próprios interesses, prioridades, excentricidades ou preconceitos - em sentido lato, a justiça enquanto equidade é uma demanda por imparcialidade ${ }^{90}$. Nesse contexto, para nossos propósitos, podemos extrair de Rawls a lição de que a justiça caracteriza-se por um constante despir-se de preconceitos - tarefa árdua, em verdade impossível. Mas o que importa é a ideia de que devemos buscar, incessantemente, tal aproximação ideal. Assim como em Smith, trata-se da busca (ou, diriam alguns, do sonho) da imparcialidade.

\footnotetext{
${ }^{86}$ SMITH, Adam. Op. cit., p. 133. Tradução livre.

${ }^{87}$ SEN, Amartya. The idea of justice. Cambridge, Massachusetts: Harvard University Press, 2009, p. 45.

${ }^{88}$ RAWLS, John. A theory of justice. Cambridge, Massachusetts: Harvard University Press, 1999, Revised edition.

${ }^{89}$ RAWLS, John. A theory of justice. Cambridge, Massachusetts: Harvard University Press, 1999, Revised edition, pp. 118-123.

${ }^{90}$ SEN, Amartya. Op. cit., p. 54.
} 
Note-se que a imparcialidade pode ser fechada ou aberta. Para os que defendem a imparcialidade fechada, como Rawls na justiça enquanto equidade ${ }^{91}$, os julgamentos imparciais invocam apenas os membros da sociedade para a qual são direcionados (ou seus representantes); ao passo que a imparcialidade aberta aceita julgamentos e argumentos externos, de modo a evitar uma tendenciosidade provinciana ${ }^{92}$.

Como defende Pogge, a nacionalidade é apenas mais uma contingência profunda (assim como as características genéticas, a etnia, o gênero, a classe social etc), não havendo razão para tratá-la diferentemente das demais circunstâncias arbitrárias no sentido rawlsiano - o sistema fechado deve, nesse sentido, ser o mundo inteiro ${ }^{93}$.

Em verdade, hoje há uma questão subjacente, que é a própria viabilidade da imparcialidade fechada, na medida em que a "sociedade para a qual os julgamentos são direcionados" é indeterminável. Sobretudo no atual cenário de interdependência mundial, decisões tomadas localmente possuem, invariavelmente, repercussões para além de um contexto social que só é fechado no imaginário. Nesse sentido, seguimos a visão de Sen, que defende que é a imparcialidade aberta - nos moldes do espectador imparcial de Adam Smith - que necessita de reafirmação, neste mundo interconectado em que vivemos ${ }^{94}$.

Em um primeiro nível, imparcialidade significa a aplicação não parcial de determinada norma; em um segundo nível, ser imparcial significa excluir a própria existência de normas baseadas em interesses puramente egoísticos, sendo necessário justificar imparcialmente as normas em questão ${ }^{95}$.

Justificativas imparciais devem passar nos testes da reciprocidade e da generalidade. Reciprocidade significa: (i) que nenhuma das partes envolvidas deve demandar privilégios que negue às demais; e (ii) que a relevância e peso das demandas em jogo não devem ser determinados de modo unilateral ${ }^{96}$. Já generalidade significa que todos aqueles envolvidos possuem um igual direito a exigir justificações ${ }^{97}$. Conforme defende

\footnotetext{
${ }^{91}$ Em outra obra, Rawls propõe a extensão das ideias da posição original e do véu da ignorância para a sociedade internacional. No entanto, Rawls não sugere que isso leve em conta um contrato original entre todos os indivíduos do mundo, considerados como iguais. A posição original internacional, para o autor, diria respeito antes a um acordo entre representantes de cada sociedade doméstica, considerada como um todo, fechada (Veja-se: RAWLS, John. The Law of Peoples, Critical Inquiry, Autumm 1993, pp. 36-68).

92 SEN, Amartya. Op. cit., p. 123. Veja-se também a introdução de Amartya Sem à edição aqui utilizada da Teoria dos Sentimentos Morais (SMITH, Adam. Op. cit., p. 17).

${ }^{93}$ POGGE, Thomas. Realizing Rawls. Ithaca: Cornell University Press, 1989, p. 247, apud TAN, Kok-Chor. Op. cit., p. 56.

${ }^{94}$ SEN, Amartya. Op. cit., p. 152.

${ }^{95}$ Veja-se: GOSEPATH, Stefan. Op. cit., p. 146.

${ }^{96}$ FORST, Rainer. Towards a critical theory of transnational justice. In: POGGE, Thomas W. (org.). Global justice. Malden, MA: Blackwell Publishing, 2001, pp. 176-177.

${ }^{97}$ Idem.
} 
Forst, o direito básico à justificação está no núcleo tanto do âmbito doméstico quanto da estrutura transnacional, havendo um ponto de partida cosmopolita a permitir a consideração adequada dos vários contextos de justiça (do local ao global), enquanto contextos de justificação e de autodeterminação ${ }^{98}$.

No que se refere ao conteúdo da justiça, Rawls acredita que, na posição original hipotética, as partes conseguiriam chegar a um acordo a respeito de seus princípios ótimos $^{99}$. Sen (um de seus grandes discípulos), porém, discorda dessa conclusão. Para este último, talvez não haja qualquer acordo quanto à configuração de uma sociedade justa, mesmo sob as mais estritas condições de imparcialidade e análise de mente aberta - é a questão da viabilidade de uma solução transcendental acordada ${ }^{100}$.

A abordagem de Sen também se distancia do contratualismo de Rawls quanto aos objetivos - para Sen, é necessária uma estrutura comparativa que permita escolher entre alternativas viáveis que a realidade concreta apresente, e não a identificação de uma solução transcendental possivelmente inatingível - é a questão da redundância da busca de uma solução transcendental ${ }^{101}$.

A busca por justiça não pode, sob pena de autofagia, manter-se circunscrita aos limites de determinada soberania. Há dois fundamentos principais para tal afirmação: (i) em um mundo interdependente, é preciso considerar os interesses de outros povos, de forma a ser equânime e evitar tendenciosidades; e (ii) as perspectivas de outros povos

\footnotetext{
${ }^{98}$ FORST, Rainer. Op. cit., p. 178.

${ }^{99}$ RAWLS, John, op. cit., p. 121.

${ }^{100}$ SEN, Amartya. The idea of justice. Cambridge, Massachusetts: Harvard University Press, 2009, pp. 8-27. As teorias de Rawls e Sen remetem-nos ao debate entre o idealismo de Platão, para quem a verdade reside no mundo das ideias, e o realismo de Aristóteles, o qual concentra sua busca pela verdade na realidade concreta. Essa tensão entre idealismo e realismo, portanto, acompanha o pensamento ocidental há pelo menos dois mil e trezentos anos.

${ }^{101}$ SEN, Amartya. Op. cit., pp. 8-27; p. 57. Sen ilustra o problema com o dilema de decidir entre três crianças que disputam uma flauta. Uma delas (Anna) é a única das três que sabe tocá-la. Já a segunda (Bob) é tão pobre que necessita mais da flauta do que as outras duas, enquanto a terceira (Carla) trabalhou cuidadosamente durante meses para produzir a flauta, argumentando que não deve ser expropriada. Sen acredita que, nesse caso, há três razões imparciais e não arbitrárias para dar a flauta a qualquer uma das três. $\mathrm{O}$ autor do presente estudo propôs ao Professor Amartya Sen, em e-mail datado de 06.06.2011, a seguinte solução: a criança que produziu permaneceria com a flauta, locando-a à criança que sabe tocar, e sobre tal negócio incidiria um tributo, tributo este direcionado de modo a amenizar a pobreza da criança que se encontra fora do mercado de flautas. Eis a resposta do Professor de Harvard a este autor, enviada em e-mail datado de 07.06.2011: "There are many hybrid solutions that may be worth considering. But they do not make the problem go away. Carla may not want to get only money from the flute - she wants to play the flute that she has herself made. It is not just a demand of capital (as you suggest), but also entitlement to her labour in making the flute (as she sees it - and labour theorists of value would agree with her). Similarly Bob may think that he needs more than just the little share he may end up getting in your hybrid arrangement. And so on. In general, when a philosophical conflict is faced, we have to address it, rather than avoiding the conflict through some engineering solution".
} 
enriquecem nossa própria investigação, o que possibilita evitar um subdebatido provincianismo de valores e presunções na comunidade local ${ }^{102}$.

Para Held ${ }^{103}$, dois "metaprincípios" justificam a perspectiva cosmopolita: (i) o metaprincípio da autonomia; e (ii) o metaprincípio do raciocínio imparcial. O primeiro diz respeito à noção de que todas as pessoas são livres e iguais - ideia central das democracias modernas, ainda que pertencentes a comunidades distintas. O segundo, por sua vez, impõe raciocinar a partir do ponto de vista de outros - testando a validade intersubjetiva das nossas concepções sobre o bem.

Parece possível traçar clara relação entre a autonomia do ser humano, de Held, e os interesses de outros povos, de Sen; bem como entre o teste da validade intersubjetiva das nossas concepções, de Held, e a utilidade de recorrer às perspectivas de outros povos, de Sen. Para considerar adequadamente os interesses de outros povos, é preciso tratar todos os seres humanos, independentemente da comunidade à qual pertencem, como livres e iguais em princípio. Além disso, os pontos de vista externos auxiliam no aperfeiçoamento dos valores e práticas locais.

Assim é que Sen defende que o não-provincianismo é um requisito da justiça - é preciso escapar da "armadilha do provincianismo"; porquanto se a justiça ficar confinada a apenas uma localidade, há o perigo de se ignorarem ou negligenciarem muitos contraargumentos imprescindíveis à perspectiva imparcial ${ }^{104}$.

Se o papel da justiça, enquanto ideal, é decidir entre demandas ou pontos de vista parciais, ela deve ser independente, na maior medida possível, em relação a esses fatores parciais. Na medida em que, no contexto internacionalizado, as parcialidades frequentemente se traduzem em pontos de vista nacionais distintos, decidir de modo justo entre estes requer que não se tome por ponto de partida qualquer dessas perspectivas nacionais, mas sim que se busque a maior imparcialidade possível em relação a elas ${ }^{105}$.

Dessa forma, cremos ser possível afirmar que a perspectiva cosmopolita é uma exigência inescapável da própria ideia de justiça. Em outras palavras: ou a busca pela justiça utiliza-se do referencial cosmopolita, ou não se trata de justiça. Ressalve-se, porém, que isso não importa a aceitação de todos os argumentos vindos de fora - propensão a considerar tais argumentos não equivale a aceitar cegamente todos eles ${ }^{106}$. Em particular,

\footnotetext{
${ }^{102}$ Cf. SEN, Amartya. Op. cit., p. 402.

${ }^{103}$ HELD, David. Op. cit., pp. 81-92.

${ }^{104}$ SEN, Amartya. Op. cit., p. 403.

${ }^{105}$ Nesse sentido, veja-se: TAN, Kok-Chor. Op. cit., p. 190.

${ }^{106}$ Cf. SEN, Amartya. Op. cit., p. 407.
} 
seguindo a lição de Bobbio (cf. o item I.2.2, supra), a intolerância não deve ser tolerada, sob pena de enfraquecimento do próprio sistema aberto e imparcial.

\subsection{Alguns parâmetros cosmopolitas}

Neste ponto do estudo, a partir dos elementos já estudados, é possível resumir alguns parâmetros que consideramos centrais ao marco teórico cosmopolita, sob a ótica dos quais teorias e institutos podem ser revisitados. São eles: (i) a necessidade de avanço do cosmopolitismo empírico-analítico; (ii) a ideia de que o indivíduo é a unidade fundamental de consideração moral; (iii) a imparcialidade aberta enquanto postulado teórico; e (iv) a busca de equilíbrio entre uma estrutura geral de respeito à diferença e um mínimo com pretensões universais.

\subsubsection{Necessidade de avanço do cosmopolitismo empírico-analítico}

O nacionalismo metodológico, ao trabalhar com a dualidade estrangeiro/nativo composta por categorias mutuamente excludentes, está despreparado para capturar a realidade dos nossos dias ${ }^{107}$, em que os vínculos cada vez mais se tornam plurais, simultâneos, multidimensionais e dinâmicos.

A pluralidade e a simultaneidade traduzem-se na possibilidade de um mesmo agente ou fato da vida encontrar-se vinculado a mais de um contexto social a um só tempo. Por multidimensionalidade, compreenda-se que tais vínculos abrangem dimensões diversas, que nem sempre guardarão coerência entre si (imaginemos, para ilustrar, um indivíduo que resida em um país, tenha sua subsistência atrelada à economia de outro, sinta-se afetivamente ligado a um terceiro e pratique a religião prevalecente em um quarto). Por fim, note-se que tais vínculos não são estáticos, tendo a velocidade com que se modificam aumentado nos últimos tempos - seja através da imigração, da constituição de uma família plurinacional ou de uma simples mudança de emprego, as conexões múltiplas de um indivíduo podem se alterar e se reagrupar - daí a dinamicidade.

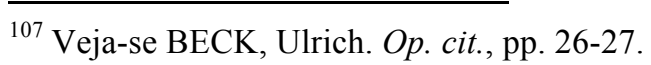


Sendo o nacionalismo metodológico reducionista, por haver sido concebido para uma realidade social que não mais existe, frequentemente revela-se inapto a lidar com questões da sociedade cosmopolita. Em outro trabalho ${ }^{108}$, defendemos que vínculos múltiplos dificultam, por exemplo, a eficácia de políticas concorrenciais nacionais paternalistas (que visam à promoção de "campeões nacionais"), uma vez que a própria diferenciação entre empresas nacionais e estrangeiras mostra-se problemática. Explique-se: a mesma sociedade empresária pode ter seu capital detido por sócios situados em países diversos, bem como exercer atividade econômica de modo disperso em vários continentes (o que envolve interesses de diferentes trabalhadores, credores, governos etc situados nas mais diversas localidades). Nesse cenário, que critério rígido absolutamente seguro pode ser utilizado para distinguir entre empresas nacionais e estrangeiras, que leve em conta todos os interesses envolvidos? Provavelmente nenhum, o que revela a arbitrariedade da própria diferenciação.

Desse modo, é necessário o desenvolvimento de um cosmopolitismo científico apto a trabalhar com contextos de simultaneidade e interpenetração. Sob pena de perpetuarmos um aparato teórico inadequado à realidade social em que vivemos, é imprescindível o reconhecimento dos vínculos múltiplos transfronteiriços em sua complexidade. Especificamente, o avanço do cosmopolitismo empírico-analítico implica a aferição de graus de vinculação com contextos sociais diversos, em oposição à arbitrariedade de categorizações absolutas baseadas em critérios únicos, como nacionalidade ou territorialidade. Assim, torna-se possível estimar a posição relativa dos agentes e fatos sociais objetos de análise.

\subsubsection{Indivíduo como unidade fundamental de consideração moral}

Um segundo parâmetro importante encontrado nos autores cosmopolitas é a ideia de que os seres humanos são os destinatários finais de consideração moral, e não os Estados ou outras formas de associação. Desse modo, todas as pessoas fazem jus a iguais respeito e consideração, independentemente de sua origem ou nacionalidade. Como afirma

\footnotetext{
${ }^{108}$ VALENTE DOS REIS. Gabriel. Direito concorrencial internacionalizado - entre a teoria dos efeitos e os efeitos da teoria. Revista de Direito Constitucional e Internacional, no 73, 2010, pp. 303-329.
} 
Held, tal individualismo igualitário, no plano internacional, não nega a importância da diversidade cultural (muito pelo contrário), porém afirma que há limites para a validade moral de comunidades particulares ${ }^{109}$.

$\mathrm{Na}$ lição de Tan, "na perspectiva cosmopolita, princípios de justiça devem transcender nacionalidade e cidadania, aplicando-se de modo igual a todos os indivíduos do mundo" $" 110$. Isso faz com que a prioridade a compatriotas deva ser rejeitada, uma vez que a demanda moral cosmopolita no sentido de que cada indivíduo faz jus a igual respeito resulta na visão de que a nacionalidade, do ponto de vista moral, é apenas uma contingência ${ }^{111}$. Em outras palavras, podemos distinguir entre pessoas no plano da identificação ou da afetividade, mas não no plano moral - nosso senso de moral e justiça não deve fazer distinções conforme a nacionalidade.

Assim, em resumo, o individualismo igualitário cosmopolita importa dois requisitos: (i) o de que devemos nos concentrar em tratar adequadamente os indivíduos, e não em promover interesses estatais ou nacionais per se (os diversos Estados e comunidades políticas devem ser vistos enquanto instrumentos de realização humana, e não como fins em si mesmos); e (ii) o de que todos os seres humanos fazem jus a iguais respeito e consideração, independentemente de sua nacionalidade.

Note-se que o individualismo igualitário cosmopolita constitui fundamento do Direito Internacional dos Direitos Humanos. Com efeito, o art. $2^{\circ}, \mathrm{n}^{\mathrm{o}} 1$, da Declaração Universal dos Direitos Humanos da ONU, de 1948, estatui que

\footnotetext{
"toda pessoa tem capacidade para gozar os direitos e as liberdades estabelecidos nessa Declaração, sem distinção de qualquer espécie, seja de raça, cor, sexo, língua, religião, opinião política ou de outra natureza, origem nacional [grife-se] ou social, riqueza, nascimento, ou qualquer outra condição".
}

No mesmo sentido, o art. $2^{\circ}, \mathrm{n}^{\mathrm{o}} 1$, do Pacto Internacional de Direitos Civis e Políticos, de 1966, estabelece que

\footnotetext{
${ }^{109}$ HELD, David. Op. cit., pp. 69-70.

${ }^{110}$ TAN, Kok-Chor, Op. cit., p. 1.

${ }^{111}$ Veja-se, nesse sentido: POGGE, Thomas. Realizing Rawls. Ithaca: Cornell University Press, 1989, p. 247.
} 


\begin{abstract}
"os Estados-partes no presente Pacto comprometem-se a garantir a todos os indivíduos que se encontrem em seu território e que estejam sujeitos à sua jurisdição os direitos reconhecidos no presente Pacto, sem discriminação alguma por motivo de raça, cor, sexo, língua, religião, opinião política ou de qualquer outra natureza, origem nacional [grife-se] ou social, situação econômica, nascimento ou qualquer outra situação". Portanto, apesar de os povos possuírem direito à autodeterminação $\left(\operatorname{art.~} 1^{\circ}\right.$ ), não se permite que esta seja utilizada para discriminar não nacionais, no que se refere à garantia dos direitos protegidos no Pacto.
\end{abstract}

Para a moralidade igualitária, cada indivíduo deve ser tratado como uma pessoa igual e autônoma, de um ponto de vista imparcial ${ }^{112}$. Como leciona Dworkin, as pessoas têm um direito moral a serem tratadas com iguais respeito e consideração ${ }^{113}$. Por conseguinte, qualquer tratamento diferenciado só pode ser justificado: (i) com base em diferenças relevantes; e (ii) por razões universalmente aceitáveis ${ }^{114}$. A igualdade, portanto, é umbilicalmente ligada à imparcialidade.

\title{
2.5.3. Imparcialidade aberta enquanto postulado teórico
}

Vimos no item I.2.4, supra, a importância da ideia de imparcialidade para a justiça, bem como seu significado no contexto cosmopolita. Se, seguindo a filosofia moral de Smith, o ser humano possui uma inclinação natural à defesa dos seus próprios interesses e daqueles de quem se sente mais próximo, é preciso promover uma conscientização que freie, racionalmente, essa tendência instintiva. Utilizando a ideia do espectador imparcial, de Smith, é preciso colocar-se em uma posição hipotética de neutralidade, a partir da qual é possível julgar os diversos interesses com imparcialidade ${ }^{115}$.

\footnotetext{
${ }^{112}$ GOSEPATH, Stefan. Op. cit., p. 148.

113 DWORKIN, Ronald. Taking rights seriously. Cambridge, MA: Harvard University Press, 1977, p. 179 apud GOSEPATH, Stefan. Op. cit., p. 148.

${ }^{114}$ GOSEPATH, Stefan. Op. cit., p. 149.

${ }^{115}$ Como vimos, essa posição hipotética neutra também está presente no véu da ignorância de Rawls. Ainda que este originalmente diga respeito a uma sociedade fechada; outros, como Pogge, estenderam-no na direção cosmopolita, acreditando que não há motivos para manter a ideia circunscrita a uma sociedade nacional, como propôs Rawls.
} 
No contexto cosmopolita, os pontos de vista nacionais distintos refletem parcialidades. Sendo assim, decidir de modo justo entre elementos das diversas perspectivas nacionais requer que não se tome por ponto de partida uma delas, mas sim que se busque a maior imparcialidade possível em relação às mesmas ${ }^{116}$.

Tal imparcialidade deve ser aberta, atentando-se para os interesses e perspectivas dos diversos membros da sociedade cosmopolita, marcada pela interpenetração e simultaneidade de vínculos. Desse modo, é possível, de um lado, tratar adequadamente as demandas de todos aqueles que interagem no contexto cosmopolitizado; e, de outro, considerar suas perspectivas, evitando-se um subdebatido provincianismo local de valores $^{117}$.

\subsubsection{Busca de equilíbrio entre uma estrutura geral de respeito à diferença e um mínimo universal}

O quarto parâmetro que consideramos essencial é a necessidade de se buscar um equilíbrio em meio à tensão dialética, inerente ao cosmopolitismo, entre relativismo e universalismo (veja-se o item I.2.2, supra). Nesse sentido, cabe promover uma estrutura básica de respeito à diferença; garantindo, contudo, a proteção de um mínimo universal que resguarde/promova a própria existência dessa estrutura geral de tolerância.

É preciso evitar o universalismo hegemônico, totalitário, através do qual em verdade se busca impor os próprios valores particulares, como se universais fossem. Para tanto, é essencial uma postura básica de respeito à diversidade, de tolerância em face das culturas alheias, por mais diferentes que elas sejam da nossa. Por outro lado, deve haver alguns limites à tolerância cosmopolita, necessários à preservação da própria estrutura de tolerância e do núcleo da dignidade humana.

Assim, defendemos que é preciso, como regra geral, tolerar a existência de culturas e pontos de vista diferentes, ainda que não concordemos completamente com suas implicações. O contraponto é que tais pontos de vista sejam, excepcionalmente, rechaçados

\footnotetext{
${ }^{116}$ Nesse sentido, veja-se item I.2.2, supra; e TAN, Kok-Chor. Op. cit., p. 190.

${ }^{117}$ Aqui, segue-se a linha de raciocínio de Sen, já mencionada (cf. item I.2.2, supra) - SEN, Amartya. Op. cit., pp. 402-403.
} 
(e substituídos por noções mínimas de justiça com pretensões universais), quando importarem riscos significativos à própria ideia de tolerância ou violações graves a requisitos mínimos de dignidade humana que, por nos serem tão caros, não estamos dispostos a relativizar. 


\section{CAPÍTULO II}

\section{JUSTIÇA COSMOPOLITA E DIREITO INTERNACIONAL PRIVADO}

SUMÁRIO: 1. A cosmopolitização do direito. 2. Cosmopolitismo e provincianismo no Direito Internacional Privado. 3. Justiça conflitual e justiça material no Direito Internacional Privado uma falsa dicotomia.

\section{A COSMOPOLITIZAÇÃO DO DIREITO}

Os tempos atuais são marcados por um paradoxo: enquanto a realidade tornou-se cosmopolita, com o crescimento exponencial da interação e interdependência transfronteiriças, as estruturas de pensamento prevalecentes permanecem atreladas ao nacionalismo metodológico. Nesse sentido, a cosmopolitização pode ser concebida, na lição de Beck, como "um programa de reeducação forçada em abertura para o mundo"118, devendo a visão cosmopolita abranger, criticar e transformar a visão nacional ${ }^{119}$.

O direito insere-se nesse contexto, cumprindo refletir sobre a teoria jurídica a partir do referencial cosmopolita, podendo este fornecer parâmetros para a crítica e transformação daquela. Aqui, é útil a ideia de Janda, que defende uma análise jurídica transistêmica, conduzindo à prática de abrir ordens jurídicas e tradições mutuamente, permitindo que umas vivam no interior das outras ${ }^{120}$. No contexto cosmopolita, a justiça e a ideia de uma "democracia por vir" talvez requeiram que as concepções jurídicas domésticas não apenas acomodem como estejam abertas a serem modificadas pela presença de estrangeiros $^{122}$.

\footnotetext{
${ }^{118}$ BECK, Ulrich. Op. cit., p. 102.

${ }_{119}$ Cf. BECK, Ulrich. Op. cit., p. 94.

${ }^{120}$ JANDA, Richard. Toward cosmopolitan law. McGill Law Journal, v. 50, 2005, p. 981.

${ }^{121}$ Janda toma emprestada a expressão "democracia por vir" de Derrida (DERRIDA, Jacques. Op. cit., p. 23.)

122 JANDA, Richard. Op. cit., p. 982.
} 
$\mathrm{Na}$ concepção kantiana ${ }^{123}$, a ordem cosmopolita possui estrutura tríplice, envolvendo o direito doméstico (leis entre cidadãos), o direito internacional tradicional (leis entre Estados) e o direito cosmopolita, a ser paulatinamente desenvolvido (leis entre Estados e indivíduos, sobretudo estrangeiros, e leis entre indivíduos) ${ }^{124}$. Impor-se-ia, assim, a criação de uma nova camada de normas na esfera cosmopolita, apta a densificar as obrigações dos Estados perante estrangeiros e entre os próprios indivíduos no plano internacional, submetendo-os à teoria moral cosmopolita ${ }^{125}$.

A partir da linha de raciocínio kantiana, muitos autores defendem o avanço do cosmopolitismo institucionalizado ${ }^{126}$. Held, por exemplo, defende um modelo baseado em oito princípios concernentes à estrutura política internacional ${ }^{127}$. No entanto, apesar do esforço teórico do autor, sua proposta parece utópica em face da atual conjuntura internacional. Ao passarmos da teoria moral cosmopolita para o cosmopolitismo institucional, permanece incerto como atingir uma ordem jurídica internacional mais densa a partir do quadro atual ${ }^{128}$. Como já afirmado, a construção da ordem política internacional envolve negociações extremamente problemáticas, e guarda consigo o risco do déficit democrático - i.e., de desaguar em uma tirania global.

Levando-se isso em conta, é preciso observar que qualquer movimento viável rumo a uma condição cosmopolita deve partir das circunstâncias atuais, onde os Estados (para o bem e para o mal) permanecem enquanto estruturas políticas dominantes ${ }^{129}$. Consequentemente, é possível referir-se a um cosmopolitismo jurídico de transição, baseado no modelo kantiano, que aceita que precisamos aperfeiçoar a ordem atual, sem contudo abandonar a preocupação com o valor do ser humano ${ }^{130}$.

$\mathrm{Na}$ interpretação de Brown, a visão kantiana implica mecanismos jurídicos que permitam aos seres humanos, pacificamente, associarem-se, comunicarem-se e trocarem

\footnotetext{
${ }^{123}$ Sobre o cosmopolitismo kantiano, veja-se o item I.1.2, supra.

${ }^{124}$ Veja-se BROWN, Garrett Wallace. Op. cit., p. 435. Veja-se, também, HELD. Op. cit., p. 92.

${ }^{125}$ Veja-se BROWN, Garrett Wallace. Op. cit., p. 438.

${ }^{126}$ Sobre o cosmopolitismo institucionalizado, veja-se o item 1.3.3, supra.

${ }^{127}$ São eles: (i) iguais valor e dignidade do ser humano, (ii) representação ativa, (iii) responsabilidade pessoal e accountability, (iv) consentimento, (v) procedimento de tomada de decisão coletiva através do voto, (vi) inclusividade e subsidiariedade, (vii) vedação a danos sérios; e (viii) sustentabilidade (HELD, David. Op. cit., p. 99).

${ }^{128}$ Em sentido semelhante: BROWN, Garrett Wallace. Op. cit., p. 441.

${ }^{129}$ BROWN, Garrett Wallace. Op. cit., p. 444.

${ }^{130}$ Cf. BROWN, Garrett Wallace. Op. cit., p. 445.
} 
ideias sem serem maltratados, bem como exercerem comércio uns com os outros, sob um conceito mutuamente consistente de hospitalidade ${ }^{131}$.

Em especial, acreditamos ser possível um esforço teórico no sentido de repensar o direito à luz dos quatro parâmetros cosmopolitas selecionados acima ${ }^{132}$ : (i) necessidade de avanço do cosmopolitismo empírico-analítico, (ii) indivíduo enquanto unidade fundamental de consideração moral, (iii) imparcialidade aberta como postulado teórico; e (iv) busca de equilíbrio entre o respeito à diferença e um mínimo universal.

O primeiro parâmetro traduz-se no próprio reconhecimento de que a prática jurídica atual, fundada em sistemas jurídicos nacionais em larga medida fechados, é insuficiente, em face da complexidade dos vínculos múltiplos de uma realidade cosmopolitizada.

O segundo implica um direito voltado para o ser humano, colocando-o no centro da ordem jurídica, em lugar de enxergar esta como um meio de perseguir interesses nacionais ou promover identidades nacionais, muitas vezes em detrimento da vida concreta dos seres humanos, sobretudo estrangeiros.

O terceiro parâmetro (imparcialidade aberta) requer, de um lado, que haja um esforço dos sistemas jurídicos no sentido de, cada vez mais, transcender seu traço histórico nacionalista, contemplando uma posição hipotética de neutralidade em relação aos sistemas nacionais parciais. De outro, que se proceda a uma abertura do direito doméstico de modo a considerar, cada vez mais, os pontos de vista de outras culturas, aprendendo e se aperfeiçoando a partir deles.

Sendo requisitos da justiça cosmopolita o tratamento adequado dos interesses de outros povos, bem como a consideração de suas perspectivas (Amartya Sen) ${ }^{133}$, duas disciplinas mostram-se essenciais enquanto instrumentos do cosmopolitismo jurídico: o Direito Comparado e o Direito Internacional Privado.

O Direito Comparado relaciona-se à exigência de consideração das perspectivas de outras culturas jurídicas. Por meio do método comparativo, é possível fazer observações e

\footnotetext{
${ }^{131}$ BROWN, Garrett Wallace. Op. cit., p. 446.

${ }^{132}$ Cf. item I.2.5, supra.

${ }^{133}$ Veja-se o item 1.3.4, supra; e SEN, Amartya. Op. cit., p. 402.
} 
tirar conclusões que não seriam possíveis caso nos limitássemos ao estudo do direito de um único país ${ }^{134}$. Como pontifica Kamba:

"quando se fica confinado ao estudo do direito do próprio país, portanto dentro do próprio ambiente cultural, há uma grande tendência a se aceitar sem questionamentos os vários aspectos (normas, conceitos e instituições) do próprio sistema jurídico" ${ }^{\text {135. }}$.

Não viajar além das fronteiras do próprio direito doméstico tende a alimentar o isolamento jurídico e o provincianismo, que são incompatíveis com o espírito científico ${ }^{136}$. Observe-se que, na maioria das épocas e locais, a cultura jurídica teve caráter transnacional, tendo sido este o caso na Europa continental até o séc. XIX - a noção de sistemas jurídicos nacionais hermeticamente fechados é um subproduto do positivismo jurídico nacionalista do séc. $\mathrm{XIX}^{137}$. Com efeito, parece preciso retomar esse espírito transnacional.

Já o Direito Internacional Privado, cuja função é proporcionar respostas adequadas às situações privadas internacionais (i.e., relações jurídicas privadas que possuem contato com mais de um sistema jurídico) ${ }^{138}$, liga-se ao tratamento adequado dos interesses dos estrangeiros. Além disso, assim como o Direito Comparado, o Direito Internacional Privado contribui para a consideração das perspectivas de outros povos, ao preconizar a aplicação, pelo juiz nacional, de direito estrangeiro, sempre que a hipótese assim exigir, por força de uma conexão. Ao se conhecer e aplicar um direito estrangeiro, aprende-se sobre possibilidades diferentes daquelas vigentes no direito do foro, o que pode conduzir, indiretamente, ao aperfeiçoamento deste.

Por fim, o quarto parâmetro cosmopolita, sob a ótica do qual também podemos refletir sobre o direito, é a necessidade de se buscar um equilíbrio apropriado entre o

${ }^{134}$ SCHLESINGER, Rudolf; BAADE, Hans; HERZOG, Peter; WISE, Edward. Comparative Law. Nova York: Foundation Press, 1998, 6 a ed., p. 2.

${ }^{135}$ KAMBA, W. J. Comparative law: a theoretical framework. International \& Comparative Law Quarterly, nº 23, 1974, p. 491. Tradaução livre.

${ }^{136}$ KAMBA, W. J. Op. cit., pp. 491-492.

${ }^{137}$ SCHLESINGER, Rudolf; BAADE, Hans; HERZOG, Peter; WISE, Edward. Op. cit., p. 11. Os autores citam ainda o Código de Hamurabi (séc. XVII a.C.) e o Antigo Testamento, que continham normas derivadas de fontes orientais; as leis de Solon, que teriam sido influenciadas pelo estudo das leis de outras cidades gregas; bem como estudos comparativos que precederam a edição da Lei das Doze Tábuas romana.

${ }_{138}$ FÉRNANDEZ ROZAS, José Carlos; LORENZO, Sixto Sánchez. Derecho Internacional Privado. Madrid: Thomsom Civitas, 2004, 3ª ed., p. 27. 
particular e o universal, entre uma estrutura geral de respeito à diversidade e um mínimo universal inegociável. Como afirma Post, "um desafio fundamental do nosso tempo é a construção de uma teoria jurisprudencial capaz de conciliar a universalidade dos direitos humanos com a parcialidade do direito positivo" ${ }^{\text {"139. }}$.

O escopo da presente dissertação é analisar o instituto da determinação da lei aplicável (ou método conflitual) sob a ótica do cosmopolitismo, focando nesses quatro parâmetros de reflexão. Nesse contexto, acreditamos que a teoria da determinação da lei aplicável, e o Direito Internacional Privado de uma maneira geral, são imprescindíveis para o processo de cosmopolitização do direito.

Observe-se que o Direito Internacional Privado surgiu por volta dos sécs. XII e XIII, em meio à efervescência das Cidades-Estados do norte da Itália. Como afirma Gutzwiller, "tais cidades não viviam isoladamente: sua liberdade, seu comércio, o temperamento de seus habitantes suscitavam relações contínuas e consequentemente regras sobre a aplicação de leis concorrentes" ${ }^{140}$. Em outras palavras, a disciplina surgiu, já em seus primórdios, como resposta a uma realidade, em larga medida, cosmopolitizada.

No contexto contemporâneo, o Direito Internacional Privado lida com a regência da vida concreta do ser humano no plano internacional, com a abertura dos direitos nacionais a seus pares; e, frequentemente, depara-se com o dilema entre respeitar valores diferentes dos nossos ou promover valores tidos por universais. Além disso, o estudo da disciplina insere-se no contexto de avanço do cosmopolitismo empírico-analítico no direito, ou, em outras palavras, de busca por maior adequação da teoria jurídica à realidade cosmopolitizada. O fato de o Direito Internacional Privado espraiar-se por quase todas as disciplinas jurídicas, sendo um "pot-pourri" que contém elementos de todas as áreas do direito $^{141}$, aumenta ainda mais seu potencial mediador e transformador, neste mundo de transição em que vivemos. Dessa forma, cumpre, cada vez mais, promover o ensino e pesquisa da disciplina.

\footnotetext{
139 POST, Robert. Another cosmopolitanism - The Berkeley Tanner lectures. Nova York: Oxford University Press, 2006, p. 3.

${ }^{140}$ GUTZWILLER, Max. Le développement historique du Droit International Privé, Recueil des Cours, v. 29, 1929, p. 298.

${ }^{141}$ SOMMIÈRES, Vareilles. La synthèse du Droit International Privé, p. 35, apud DOLINGER, Jacob. Direito Internacional Privado - Parte Geral. Rio de Janeiro: Forense, 2011, 10 a ed., p. 33.
} 


\section{COSMOPOLITISMO E PROVINCIANISMO NO DIREITO INTERNACIONAL PRIVADO}

De que forma o Direito Internacional Privado pode ser relacionado ao cosmopolitismo jurídico kantiano ${ }^{142}$ ? A esse respeito, Jean-François Kervégan faz uma interessante proposição teórica: se o cosmopolitismo de Kant pressupõe a prerrogativa jurídica de os estrangeiros interagirem com os locais, como visto acima, é possível interpretar que

\footnotetext{
"o direito cosmopolita, compreendido em seu significado estrito, ocupa em Kant o lugar daquilo que hoje chamamos de Direito Internacional Privado: ele possui vocação para enquadrar normativamente as práticas econômicas e comerciais fora do território nacional, de modo a permitir, de um lado, uma 'mundialização' das trocas, e de outro prevenir os excessos, como a selvageria da colonização" ${ }^{\text {143 }}$.
}

Note-se que Kervégan ressalva, ainda, que "comércio" (Verkehr, commercium), em Kant, não se resume às trocas econômicas, mas compreende outros tipos de interação ${ }^{144}$ trata-se do comércio em sentido amplo. Sendo assim, a ideia de cosmopolitismo é essencial para compreender e desenvolver o Direito Internacional Privado.

Outra é a visão de Ricardo Lobo Torres, para quem o direito cosmopolita se distingue do Direito Internacional Privado, na medida em que este envolveria questões entre particulares dependentes de soluções proferidas por Estados soberanos ${ }^{145}$. Assim, o autor sustenta que somente

\footnotetext{
"alguns aspectos mais atuais do relacionamento entre empresas é que podem cair no campo do direito cosmopolita, como acontece com a lex mercatoria, as arbitragens internacionais, a proteção da concorrência, os
}

\footnotetext{
${ }^{142}$ Sobre o cosmopolitismo kantiano, veja-se o item I.1.2, supra.

${ }^{143}$ KERVÉGAN, Jean-François. Le droit cosmopolitique comme droit. Logos, no 42, Madrid, 2009, pp. 9-24. Tradução livre.

${ }^{144}$ KERVÉGAN, Jean-François. Op. cit., p. 22.

${ }^{145}$ TORRES, Ricardo Lobo. Op. cit., p. 925.
} 
relacionamentos submetidos aos organismos não-estatais e a garantia dos direitos humanos" ${ }^{146}$.

Discordamos, nesse ponto, do ilustre autor. Em primeiro lugar, o jus cosmopoliticum kantiano, enquanto direito fundado na hospitalidade com que os Estados devem tratar os estrangeiros, é claramente um direito dependente da conduta estatal - desse modo, ainda que o Direito Internacional Privado estivesse submetido exclusivamente às soluções proferidas por Estados soberanos (o que não parece ser o caso, vide as inúmeras Convenções da Haia sobre Direito Internacional Privado, as Convenções Interamericanas de Direito Internacional Privado - CIDIPs, a influência dos julgamentos da Corte Europeia de Direitos Humanos no âmbito do Direito Internacional Privado europeu etc), tal dependência não afastaria nossa disciplina da ideia de cosmopolitismo.

Em segundo lugar, conforme já afirmado ${ }^{147}$, visualizamos o cosmopolitismo enquanto orientação teórica mais ampla, a informar a interpretação e aplicação de variados tipos de normas, e não como um ramo do direito específico, sem prejuízo da acertada visão de Kervégan, no sentido de que o direito cosmopolita de Kant e o Direito Internacional Privado aproximam-se consideravelmente em objeto e propósito ${ }^{148}$.

É digno de nota que a doutrina especializada, há muito tempo, reconhece que teorias e métodos podem conduzir a duas tendências opostas em nossa disciplina: a do provincianismo e a do cosmopolitismo. Nesse sentido, Werner Goldschmidt ${ }^{149}$ distingue bem duas diferenças de postura: (i) a de desconhecimento do elemento estrangeiro; e (ii) a de admissão do elemento estrangeiro enquanto tal.

No primeiro grupo, há duas subdivisões. A primeira consiste em hostilidade em relação ao estrangeiro, proibindo-o de entrar no país e descartando da esfera do direito todas as relações jurídicas que o afetem. A segunda subdivisão é a da simples indiferença, pela qual, admitindo-se relações com o estrangeiro, estas são assimiladas por completo, sendo tratadas como se relações puramente nacionais fossem.

O segundo grupo, por sua vez, divide-se em duas possibilidades. A primeira é a da não diferenciação entre os diversos estrangeiros, considerando-os todos como se fossem

\footnotetext{
${ }^{146}$ Idem.

${ }^{147}$ Item I.1.2, supra.

148 Maristela Basso também se refere ao cosmopolitismo humano enquanto fator fundamental do Direito Internacional Privado (BASSO, Maristela. Curso de Direito Internacional Privado. Atlas: São Paulo, 2009, pp. 10-14).

${ }^{149}$ GOLDSCHMIDT, Werner. Sistema y filosofia del Derecho Internacional Privado, tomo I, $2^{\text {a }}$ ed., Buenos Aires: Ediciones Jurídicas Europa-América, 1952, pp. 32-33.
} 
pertencentes a uma única classe (a expressão mais conhecida desse tipo de tratamento foi o ius gentium do direito romano). Em segundo lugar, abre-se a perspectiva da igualdade entre todos os ordenamentos, sistema pelo qual cada país mostra-se disposto a aplicar qualquer direito, a depender de qual elemento estrangeiro prevaleça no caso concreto.

Esta última atitude, de igualdade entre os sistemas jurídicos e respeito às diferenças, traduz, segundo Goldschmidt, o cosmopolitismo jurídico, único espírito autêntico no qual o Direito Internacional Privado deve se inspirar (opondo-se ao chauvinismo jurídico) ${ }^{150}$.

Enquanto a noção de chauvinismo implica um nacionalismo explícito, objeto de preocupações profundamente ligadas à experiência de vida do grande jusinternacionalista (fuga da perseguição nazista), existe também outra forma de egoísmo jurídico, mais sutil o provincianismo.

O provincianismo está um passo antes do chauvinismo - em lugar do ódio, o que se observa é o total desconhecimento, a simples falta de interesse, a completa indiferença. Traduz-se, geralmente, em uma concepção de mundo segundo a qual apenas os próprios valores estão corretos e são, portanto, superiores a todos os outros. No Direito Internacional Privado, o provincianismo relaciona-se ao fenômeno, descrito por Goldschmidt, de assimilação, por completo, da relação com elemento estrangeiro pelo direito nacional.

A lição de Haroldo Valladão é praticamente idêntica à de Goldschmidt. Após afirmar que, para decidir qual ordem jurídica deverá reger o caso, "duas medidas se ofereceriam logo, não para solucionar, mas realmente para eliminar o problema: suprimir o intercâmbio humano além de cada ordem jurídica ou acabar com a diversidade de sistemas jurídicos"; Valladão sustenta, com propriedade, que "como todos os remédios simplistas, são esses de natureza totalitária incompatíveis com o respeito à personalidade humana e à autonomia de suas manifestações sociais, com as nações, Estados, províncias, religiões etc" ${ }^{\prime 151}$.

Daí sua afirmação no sentido de que a solução fundamental do Direito Internacional Privado é antitotalitária, acata e respeita a personalidade dos indivíduos e a autonomia dos

\footnotetext{
${ }^{150}$ GOLDSCHMIDT, Werner. Op. Cit., pp. 153-154.

151 VALLADÃO, Haroldo. Direito Internacional Privado: em base histórica e comparativa, positiva e doutrinária, especialmente dos Estados americanos, vol. I, $5^{\text {a }}$ ed., Rio de Janeiro: Freitas Bastos, 1980, p. 22.
} 
diversos grupos legislativos e decorre do imperativo geral de justiça e equidade de assegurar a expansão e a continuidade da vida jurídica do ser humano no espaço ${ }^{152}$.

Já em relação ao provincianismo, ao tratar deste no âmbito do Direito Internacional Privado norte-americano (Conflict of Laws), Dolinger equipara-o à postura de "procurar aplicar sua própria lei, evitando ao máximo a aplicação de lei estrangeira" ${ }^{" 153}$. Ao buscar aplicar sua própria lei e impor seus valores a todo custo, o intérprete incorre em atitude provinciana - falta-lhe a percepção da riqueza da diversidade do mundo e do respeito devido ao elemento estrangeiro.

Mathias Reimann ${ }^{154}$, por sua vez, ao criticar o Second Restatement ${ }^{155}$ norteamericano e defender a necessidade de um Third Restatement, aponta para o fato de que aquele seria, em grande medida, cego a preocupações internacionais, porquanto herdeiro de um período de provincianismo ${ }^{156}$ na teoria norte-americana sobre o conflito de leis. Nesse sentido, Reimann fala em uma verdadeira perspectiva insular ${ }^{157}$.

Paul S. Berman, defendendo que os debates do Direito Internacional Privado envolveriam mais que simplesmente a questão de saber qual norma será aplicada a uma disputa (nomeadamente, envolveriam aspectos-chaves de definição comunitária e de afiliação), enxerga no cosmopolitismo o potencial de tornar-se uma estrutura básica para a determinação da lei aplicável ${ }^{158}$. A vantagem estaria no fato de que este busca entender as afiliações múltiplas, partindo da premissa de que os vínculos comunitários são sempre plurais e podem ser dissociados da mera localização espacial ${ }^{159}$.

Note-se que o cosmopolitismo rechaça o universalismo hegemônico. Desse modo, uma teoria cosmopolita da determinação da lei aplicável não nega as múltiplas ligações dos

\footnotetext{
${ }^{152}$ VALLADÃO, Haroldo. Op. cit., p. 218. O Professor Valladão ainda frisa que "solução contrária, de aplicar lei de todo alheia ao fato interespacial, direito que nele não incidiu nem poderia incidir, constituiria forma suprema de despotismo".

${ }^{153}$ DOLINGER, Jacob. A decadência do Direito Internacional norte-americano. In: DOLINGER, Jacob. Direito e Amor. Rio de Janeiro: Renovar, 2009, p. 196.

${ }^{154}$ REIMANN, Mathias. A new Restatement - for the international age, Indiana Law Journal, Indiana, v. 75 , pp. 575-577, 2000.

${ }^{155}$ Restatement (Second) of the Conflict of Laws, American Law Institute, 1971. Trata-se de uma compilação de práticas e recomendações para a solução de conflitos de leis no espaço, uma das principais fontes da matéria nos Estados Unidos da América.

156 Mathias Reimann, assim como a maior parte da literatura em língua inglesa, utiliza a palavra "parochialism". A expressão possui dois significados: (i) falta de dimensão internacionalista, à qual Reimann refere-se no artigo citado; e (ii) falta de dimensão comparatista. Esta última é tratada pelo autor em outro artigo (REIMANN, Mathias. Parochialism in American Conflicts Law, American Journal of Comparative Law, v. 49, n³, p. 369, 2001).

157 "Insular approach".

${ }^{158}$ BERMAN, Paul S. Choice of law and jurisdiction on the Internet - Towards a cosmopolitan vision of Conflict of Laws: redefining governamental interests in a global era, The University of Pennsylvania Law Review, v. 153, 2005, pp. 1856-1857.

${ }^{159}$ Idem, p. 1857.
} 
indivíduos com várias comunidades ${ }^{160}$. Busca, ao revés, reconhecer essa multiplicidade, em vez de dissolvê-la em uma comunidade pretensamente universal. Assim é que Berman afirma:

\begin{abstract}
"Dado que é na prática improvável e normativamente indesejável a criação de um direito global abrangente e único, as cortes devem se engajar em uma discussão permanente, e de nuances, sobre princípios de conflito de leis, de modo a acomodar tanto as particularidades de cada comunidade quanto a necessidade de regular múltiplas comunidades de forma efetiva. Tal análise de nuances considerará a afiliação comunitária, as necessidades funcionais do sistema transnacional e a possibilidade de se desenvolverem normas híbridas para casos que tocam múltiplas comunidades normativas" $" 161$.
\end{abstract}

Parece-nos que a abordagem cosmopolita defendida por Berman se assemelha, de certo modo, ao princípio da proximidade, há muito conhecido, que preconiza a aplicação do direito que possui o maior vínculo com a relação jurídica examinada. Com efeito, para se aferir a conexão mais forte, será preciso examinar os diversos vínculos do caso (objetivos e subjetivos) - o que implica reconhecer afiliações múltiplas e aferir o grau de intensidade de cada uma, de modo a optar entre elas.

Como visto, a teoria e prática do Direito Internacional Privado navegam em meio a uma tensão entre uma tendência provinciana - insular, autocrática, arrogante, cega a preocupações internacionais; e outra cosmopolita - pluralista, tolerante, respeitadora das diferenças e atenta às exigências da sociedade internacional. Esta última é a própria razão de ser da disciplina e é marcada pela consciência de que, como regra geral ${ }^{162}$, os valores alheios devem ser respeitados, por mais diferentes que sejam daqueles por nós cultivados, e de que só assim poderá haver justiça no plano internacional. No próximo item, trataremos do conceito de justiça no Direito Internacional Privado, de modo mais detalhado.

\footnotetext{
${ }^{160}$ Idem, p. 1861.

${ }^{161}$ Idem, p. 1881. Tradução livre.

162 Como toda regra geral, tal perspectiva admite exceções. É possível que, sendo determinado valor estrangeiro manifestamente contrário ao mínimo requerido pela mais basilar concepção de justiça do foro, este não esteja disposto a aplicar a solução por aquele indicada - disso trata o princípio da ordem pública de Direito Internacional Privado, previsto no art. 17 da Lei de Introdução brasileira. O mesmo pode ocorrer em relação a valores verdadeiramente internacionais. Sobre a ordem pública, veja-se o capítulo IV, infra.
} 


\section{JUSTIÇA CONFLITUAL E JUSTIÇA MATERIAL NO DIREITO INTERNACIONAL PRIVADO - UMA FALSA DICOTOMIA}

O Direito Internacional Privado busca justiça na resolução das lides transnacionais entre particulares. O método conflitual, um dos principais objetos da disciplina, cuida do direito aplicável às situações conectadas, por força das circunstâncias, a mais de um ordenamento jurídico. A par da observância de normas verdadeiramente internacionais (tratados, costumes internacionais, princípios gerais de direito etc ${ }^{163}$ ), as quais não esgotam a maior parte das questões, é necessário decidir entre esferas de juridicidade com igual pretensão de aplicabilidade a priori: os diversos ordenamentos nacionais em contato com o caso concreto.

Essa escolha - que tem como pano de fundo uma articulação horizontal - é o objeto central do presente estudo, razão pela qual é preciso analisar a noção de justiça incluindo a exigência cosmopolita - especificamente em relação à determinação da lei aplicável.

Os estudiosos do Direito Internacional Privado referem-se a duas espécies distintas de justiça: a justiça conflitual ${ }^{164}$ e a justiça material. A primeira diz respeito à atribuição de cada relação jurídica ao sistema jurídico com a qual possua maiores vínculos, por meio da técnica do conflito de leis, ao passo que a segunda refere-se ao resultado final da disputa, i.e., a uma preocupação com a efetiva solução material dada ${ }^{165}$.

Assim, a vocação primordial das regras de conexão tradicionais é determinar o direito aplicável, sem se preocupar, em um primeiro momento, com a solução de direito material prescrita pelo ordenamento jurídico em questão - nesse sentido, aponta-se para a neutralidade das regras de conexão. Tais regras procedem à localização da relação jurídica, por meio de um elemento de conexão, estando todos os ordenamentos, a priori, em pé de igualdade.

\footnotetext{
${ }^{163}$ Trata-se das principais fontes do Direito Internacional Público, previstas no art. 38 do Estatuto da Corte Internacional de Justiça, que trata também da jurisprudência e da doutrina como fontes subsidiárias. Note-se que o rol não é exaustivo - dele não constam, por exemplo, as resoluções das organizações internacionais, tampouco as declarações unilaterais dos Estados.

164 Atribui-se a origem da expressão à doutrina alemã. Veja-se, especialmente, KEGEL, Gerhard. Internationales Privatrecht, $6^{\mathrm{a}}$ ed., 1987, p. 54 apud JUENGER, Friedrich. Choice of law and multistate justice. Nova York: Transnational Publishers, 2005, special edition, p. 69.

${ }_{165}$ GAUDEMET-TALLON, Hélène. Le pluralism em Droit International Privé: richesses et faiblesses (Le funambule et l'arc-en-ciel). Recueil des Cours, v. 312, Leiden/Boston: Martinus Nijhoff Publishers, 2006, pp. 171-173.
} 
$\mathrm{Na}$ estrutura da regra de conexão tradicional, não há qualquer privilégio para o foro. Apenas em etapa posterior é que se permite a consideração de certos princípios de direito material sob a rubrica da reserva da ordem pública ${ }^{166}$, que protege excepcionalmente alguns valores locais ou verdadeiramente internacionais tidos por inegociáveis.

Segundo Hélene Gaudemet-Tallon, há três vantagens essenciais decorrentes dessa neutralidade: (i) colocando-se todas as leis em pé de igualdade, evita-se qualquer nacionalismo; (ii) afasta-se a necessidade de uma pesquisa sobre o direito material de todos os países envolvidos ${ }^{167}$; e (iii) busca-se assegurar a melhor coordenação possível das ordens jurídicas - procedendo-se a uma localização objetiva, pode-se esperar que todos os sistemas utilizem, com frequência, localizações idênticas ${ }^{168}$. Esta última afirmação, é claro, deve ser vista cum granu salis.

Uma das críticas mais veementes já desferidas contra o conceito de justiça conflitual foi a de Friedrich Juenger, para o qual a noção seria uma "marca de justiça peculiar, prontamente satisfeita pela aplicação do direito mais proximamente conectado com uma relação específica"169.

Com esse espírito, Juenger voltou-se contra toda a teoria geral do Direito Internacional Privado, ao sustentar que há uma doença subjacente, causada pela crença multilateralista de que a determinação da lei aplicável deve se preocupar com a localização das relações jurídicas, em lugar de atentar para valores materiais ${ }^{170}$. Para o autor, colocar a geografia acima da justiça jamais produzirá um sistema satisfatório ${ }^{171}$. Discordamos de Juenger quando este sugere que o Direito Internacional Privado tradicional colocaria a geografia acima da justiça, uma vez que a noção de localização das relações jurídicas não

166 BUCHER, Andreas. La dimension sociale du Droit International Privé, Recueil des Cours, v. 341, Leiden/Boston: Martinus Nijhoff Publishers, 2010, p. 54. Quanto às chamadas lois de police (normas de aplicação imediata ou internacionalmente imperativas, que não se confundem com o princípio da ordem pública), há discussão doutrinária. Enquanto alguns acham que sua aplicação dá-se antes de qualquer recurso às regras de conexão, outros acreditam que elas também constituem uma exceção a posteriori.

${ }^{167}$ Em outro trabalho, defendemos que o princípio da proximidade equivale a um postulado de ponderação no plano internacional, determinando um cuidadoso sopesamento dos elementos fáticos em relação aos sistemas jurídicos. Para proceder a esse sopesamento, em alguns casos pode ser necessário considerar, dentre outros elementos, aspectos de direito material dos ordenamentos em jogo, de modo a verificar o direito mais próximo (que não necessariamente será aquele mais justo na opinião do intérprete), cf. VALENTE DOS REIS, Gabriel. O Direito Internacional Privado e a teoria das qualificações: uma revisão do método conflitual a partir do princípio da proximidade, Revista de Direito do Estado - RDE, n 13, pp. 293-325.

168 GAUDEMET-TALLON, Hélène. Op. cit., pp. 183-195. Note-se que a professora de Paris alerta para o fato de que a regra de conexão, apesar de neutra, não é desencarnada, i.e., desligada do Estado que a editou e de sua concepção acerca da sociedade e das relações jurídicas. Desse modo, para a Professora, a busca por uma solução universal é utópica (Op. cit., pp. 187-193).

169 JUENGER, Friedrich. Op. cit., p. 69. Tradução livre.

${ }^{170}$ JUENGER, Friedrich. Op. cit., p. 131.

${ }^{171}$ Idem. 
equivale a uma localização meramente geográfica, antes conduzindo a uma análise de pertinência, que considera outros critérios além dos espaciais.

Já Lea Brilmayer, ao propor uma visão baseada na ideia de direitos políticos contra o Estado, esclarece que se faz necessário indagar se as conexões de um indivíduo com determinado Estado são suficientes para tornar equânime impor ao mesmo a concepção particular de justiça material do Estado em questão ${ }^{172}$. Nessa linha de raciocínio, o direito à representação política seria um elemento a mais a corroborar a ideia de que não se deve impor a justiça material do foro indiscriminadamente a estrangeiros, na medida em que estes não participaram dos debates públicos locais (seja através do voto, da construção da opinião pública ou de outras formas que a sociedade civil possui de influenciar os rumos da política).

Pierre Lalive, por sua vez, após afirmar que não se deve exagerar a oposição entre as duas formas de justiça, aduz que a distinção parece corresponder à realidade das coisas; e ao espírito do Direito Internacional Privado, de um lado, e do direito material, de outro $^{173}$. Ademais, para o autor, o que ocorre em nossa disciplina não é diferente daquilo que acontece em outros ramos do direito, que também possuem seus valores e parâmetros próprios, especiais (tais como o direito penal, o direito administrativo, o direito civil etc) ${ }^{174}$. Lalive deixa claro, porém, que as duas formas de justiça não são compartimentos estanques $^{175}$.

Há que se debruçar, portanto, sobre tal questão: existe uma espécie de justiça peculiar ao Direito Internacional Privado? Não acreditamos que a ideia de justiça se desmembre em duas ${ }^{176}$. Como afirma Dário Moura Vicente, a especificidade da nossa disciplina não é uma justiça própria, eminentemente formal, mas sim um objeto e método particulares ${ }^{177}$. Ou, como precisamente observa Rui Manuel Moura Ramos, "a justiça conflitual não é, no fim das contas, um outro e diverso tipo de justiça, a opor à justiça

\footnotetext{
${ }^{172}$ BRILMAYER, Lea. Rights, fairness, and choice of law, Yale Law Journal, v. 98, p. 1306, 1989.

${ }^{173}$ LALIVE, Pierre. Tendances et méthodes en Droit International Privé. Recueil des Cours, v. 155, Leiden/Boston: Martinus Nijhoff Publishers, 1977, p. 348.

${ }^{174}$ Idem.

175 Idem, p. 350.

${ }^{176}$ Observe-se que a divisão da justiça em diferentes aspectos não é uma ideia nova. Aristóteles já se referia a espécies distintas, para fins de análise, distinguindo entre justiça distributiva e justiça corretiva e entre justiça natural e justiça legal (ARISTÓTELES. Op. cit., Livro V, 1129a-1138b, pp. 103-127).

177 VICENTE, Dário Moura. Método e fontes do Direito Internacional Privado. In: VICENTE, Dário Moura. Ensaios, vol. II, Coimbra: Almedina, 2005, p. 36.
} 
material, mas antes a forma que nas relações plurilocalizadas esta necessariamente assume, 178 .

Como já afirmado, a busca pela justiça, de acordo com o referencial cosmopolita, exige o tratamento adequado dos interesses de outros povos e a devida consideração de suas perspectivas, bem como das necessidades da sociedade internacional como um todo. O único modo de o julgador aproximar-se dessa abordagem, buscando a imparcialidade, é por meio de um distanciamento de si mesmo - é preciso estar disposto a aceitar valores diferentes dos próprios, se as circunstâncias do caso concreto assim exigirem. Em suma, é preciso despir-se de preconceitos.

Como corolário do parâmetro cosmopolita da imparcialidade aberta, o intérprete deve se colocar em uma posição hipotética de neutralidade em relação aos diversos ordenamentos jurídicos nacionais, evitando privilegiar a aplicação do seu próprio direito. Tal como o homem que busca ouvir à voz do espectador imparcial, em Smith (veja-se o item I.2.4, supra), o intérprete deve se valer da razão, de forma a vencer seu instinto natural de preferir a aplicação do próprio direito.

Daí porque é desaconselhável que se busque, nas lides internacionais, aquilo que se chama de justiça material a todo custo. O intérprete precisa, humildemente, entender que está imbuído de valores individuais e sociais preconcebidos, os quais influenciam sua concepção particular de justiça. Com efeito, tais valores são relativos no plano da validade (é preciso, por vezes, aprender com visões diferentes das nossas) e no plano fático (frequentemente, valores desenvolvidos no âmbito de uma sociedade são inadequados para reger casos mais proximamente ligados a outra sociedade).

Aurea Christine Tanaka, em sentido diverso, defende a aplicação de determinados princípios na determinação da lei aplicável, de forma a primar pela justiça material ${ }^{179}$, aduzindo mais adiante que essa prática pressupõe a ideia de que há um senso comum quanto àquilo que é justo, adequado ou protetivo; e que "se este senso comum não fosse possível, a Declaração Universal de Direitos do Homem e outros documentos internacionais do mesmo tipo também não o seriam" e que "independentemente das diferenças culturais, locais, particulares dos indivíduos, povos e nações, o fato é que se

\footnotetext{
178 RAMOS, Rui Manuel Moura. Da lei aplicável ao contrato de trabalho internacional. Coimbra: Almedina, 1990, p. 255.

179 TANAKA, Aurea Christine. Princípios aplicáveis ao divórcio no Direito Internacional Privado: o caso dos brasileiros no Japão. Tese de Doutorado, Faculdade de Direito da Universidade de São Paulo - USP, 2005, p. 67.
} 
estabeleceu um consenso quanto aos princípios a serem preservados no âmbito internacional" $" 180$.

Divergimos dessa posição. Em nossa visão, o consenso internacional quanto àquilo que é justo constitui exceção, não existindo na imensa maioria dos casos. Como demonstra Paulo Borba Casella, a noção de bom e justo no plano internacional é marcada pela relatividade dos parâmetros, bem como pela subjetividade em sua formulação e aplicação ${ }^{181}$. Ainda que possa haver mecanismos de controle, observa-se grande dose de discricionariedade ${ }^{182}$.

Deve-se observar, portanto, a necessidade de se guardar independência entre os critérios para escolha da lei aplicável e a regulação material do assunto em questão ${ }^{183}$. Assim sendo, nos casos transnacionais, a noção de justiça necessita de um anteparo que a impeça de ser um esconderijo para o provincianismo, o qual acabaria por levar, em última análise, à sua autonegação - é este o aspecto conflitual ao qual os teóricos aludem.

Nesse contexto, ao se buscar a lei mais próxima ao contexto fático examinado, deve-se buscar justiça nessa determinação - justiça mediata, a qual não necessariamente implicará a solução final que o juiz (ou a cultura jurídica do foro de uma maneira geral) considere mais justa - justiça imediata ${ }^{184}$. Do contrário, estimular-se-ia uma aplicação indiscriminada da lex fori, uma vez que o juiz, na maior parte dos casos, tenderá a considerar seu direito mais justo que o direito estrangeiro. No plano internacional, a ideia de justiça precisa se proteger contra si mesma.

\footnotetext{
${ }^{180}$ TANAKA, Aurea Christine. Op. cit., p. 71. Note-se que a autora faz certa concessão que acaba por tornar sua posição contraditória, ao afirmar, em seguida: "Uma questão que permanece é a das diferentes concepções de justo, adequado e protetivo, conceitos subordinados a uma apreciação subjetiva do aplicador do direito, certamente influenciados pelas questões culturais inerentes a cada povo" (TANAKA, Aurea Christine. Op. cit., p. 72).

${ }^{181}$ CASELLA, Paulo Borba. Fundamentos do Direito Internacional pós-moderno. São Paulo: Quartier Latin, 2008, p. 115.

${ }^{182}$ Idem. O autor alerta, ainda, que isso não é muito diferente daquilo que ocorre nas ordens internas.

183 Veja-se, nesse sentido: MONACO, Gustavo Ferraz de Campos. Atribuição da guarda e suas consequências em Direito Internacional Privado. Tese de Doutorado, Faculdade de Direito da Universidade de São Paulo - USP, 2008, p. 75.

${ }^{184}$ Elaboramos tal distinção em outro trabalho (cf. VALENTE DOS REIS, Gabriel. O Direito Internacional Privado e a teoria das qualificações: uma revisão do método conflitual a partir do princípio da proximidade, Revista de Direito do Estado - RDE, n 13, pp. 293-325).
} 


\section{CAPÍTULO III}

\section{MÉTODOS DE DETERMINAÇÃO DA LEI APLICÁVEL}

SUMÁRIO: 1. Conflito de soberanias ou localização da relação jurídica privada? 2. Multilateralismo, unilateralismo e materialismo. 2.1. Multilateralismo. 2.2. Unilateralismo. 2.3. Materialismo. 2.4. Pluralismo de métodos. 2.4.1. A flexibilização das regras de conexão. 2.4.2. A publicização do direito e as lois de police. 2.4.3. Materialismo e regras de conexão substanciais. 2.4.4. Considerações críticas.

\section{CONFLITO DE SOBERANIAS OU LOCALIZAÇÃO DA RELAÇÃo JURÍDICA PRIVADA?}

Há dois modos distintos de se encarar o problema da determinação da lei aplicável. Pode-se partir das leis potencialmente aplicáveis e perquirir acerca de seu âmbito relativo de incidência; ou, ao revés, iniciar o raciocínio pelo caso concreto, i.e., pela relação jurídica que está em jogo, de modo a buscar o direito que lhe é mais próximo ${ }^{185}{ }_{-}^{186}$.

A primeira abordagem relaciona-se a uma tradição que enxerga na questão um conflito entre soberanias, sendo necessário acomodá-las reciprocamente; enquanto a segunda observa que o Direito Internacional Privado lida predominantemente com interesses de particulares, e não de Estados.

Uma boa forma de entender essas duas tendências é contrapor o núcleo da teoria do holandês Ulrich Huber (1636-1694), que influenciou a tradição norte-americana por meio de Story (1779-1845), à ideia central da teoria de Savigny (1779-1861), grande inspirador dos sistemas de matriz romano-germânica.

\footnotetext{
${ }^{185}$ DOLINGER, Jacob. Direito Internacional Privado - Parte Geral. Rio de Janeiro: Forense, 10a ed., 2011, pp. 31-32.

${ }_{186}$ Bernard Audit divide nossa disciplina em quatro grandes abordagens: (i) o método estatutário, que consiste em determinar o campo de aplicação das leis em função de seu objeto; (ii) o territorialismo, que se baseia na soberania do Estado sobre seu território; (iii) o personalismo, que se baseia na soberania do Estado em relação a seus nacionais; e (iv) o método de localização das relações jurídicas (AUDIT, Bernard. Le droit international privé en quete d'universalité, Recueil des Cours, vol. 305, Leiden/Boston: Martinus Nijhoff Publishers, 2001, p. 147 e ss.). Na divisão que propomos, os três primeiros métodos relacionam-se à ideia de concorrência entre leis, enquanto o quarto método diz respeito à lei mais adequada para reger a relação jurídica. Note-se, contudo, que a origem do método estatutário é anterior à ideia moderna de soberania.
} 
O próprio título da obra de Huber já evidencia os contornos de sua construção teórica: De conflictu legum diversarum in diversis imperiis (1689). Trata-se, portanto, do conflito entre leis diferentes - nomenclatura dada à nossa disciplina, até hoje, nos Estados Unidos da América (Conflict of Laws).

Os três conhecidíssimos axiomas de Huber são: (i) as leis de cada Estado vigem dentro dos limites de sua autoridade e obrigam todos os súditos do Estado, porém não possuem efeitos além desses limites; (ii) todas as pessoas que se encontram dentro dos limites de determinada autoridade soberana, a título permanente ou eventual, são consideradas seus súditos e, enquanto tais, restam sujeitas às suas leis; e (iii) apenas por comitas (cortesia) ${ }^{187}$ das autoridades as leis estrangeiras podem ser aplicadas, de modo que os direitos adquiridos sob sua égide conservem sua força, desde que isso não represente prejuízo aos direitos do Estado em questão ou de seus súditos ${ }^{188}$.

Vê-se claramente que o territorialismo de Huber preocupa-se fundamentalmente com a preservação da soberania do foro. Nesse contexto, a aplicação da lei estrangeira é tida como excepcional, decorrente de uma espécie de permissão do soberano. Tal territorialismo exacerbado deve ser contextualizado historicamente, na medida em que encontrava enorme ressonância no contexto da libertação dos Países Baixos frente ao subjugo dos Habsburgo espanhóis ${ }^{189}$.

Savigny, diferentemente, não se concentrou na extensão da soberania. Para ele, o objeto direto e imediato das regras jurídicas é, em primeiro lugar, a pessoa enquanto sujeito de direitos e, a seguir, a pessoa enquanto sujeito que, por atos livres, produz relações jurídicas ou concorre para produzi-las ${ }^{190}$.

Desse modo, baseado no princípio da comunidade de direito entre os diferentes povos que possuem relações entre si, Savigny planteia o problema nos seguintes termos: determinar, para cada relação jurídica, a esfera de direito mais conforme a sua natureza própria e essencial - ou seja, sua sede $e^{191}$. O autor deixa claro, ainda, que

\footnotetext{
${ }^{187}$ A tradução mais próxima da ideia de comitas seria "cortesia internacional". Maristela Basso, apoiada em Martin Wolff, alerta que a comitas era idêntica à ratio legis, com equidade e utilidade e oposto a algo incogruum et iniquim. Desse modo, a ideia de comitas da escola estatutária holandesa seria distinta da noção de cortesia internacional no sentido do Direito Internacional Público (BASSO, Maristela. Op. cit., p. 117).

${ }^{188}$ Cf. DOLINGER, Jacob. Direito Internacional Privado - Parte Geral. Rio de Janeiro: Forense, $10^{\mathrm{a}}$ ed., 2011, pp. 190-191; MCCLEAN, David. De Conflictu Legum - Perspectives on Private International Law at the Turn of the Century. Recueil des Cours, v. 282, Leiden/Boston: Martinus Nijhoff Publishers, 2000, p. 60; AUDIT, Bernard. Op. cit., pp. 167-168.

189 AUDIT, Bernard. Op. cit., pp. 167.

${ }^{190}$ SAVIGNY, Friedrich Carl Von. Op. cit., §345, p. 39.

191 SAVIGNY, Friedrich Carl Von. Op. cit.. §348, p. 50; §361, pp. 117-118.
} 
"não se deve somente ver nessa concessão o efeito de uma simples benevolência, ato revogável de uma vontade arbitrária, mas muito mais um desenvolvimento próprio do direito, seguindo seu curso a mesma marcha que seguem as normas sobre colisão entre os direitos particulares de um Estado" 192 .

Eis os dois grandes raciocínios possíveis: enxergar na determinação da lei aplicável um conflito entre soberanias, ainda que potencial, ou tratar o problema como a busca pelo direito mais apto a reger uma relação jurídica afeta à pessoa. Entendemos que, em regra, esta última perspectiva é mais apropriada. Note-se que a soberania, enquanto conceito teórico, é cada vez mais relativizada, diante da realidade da sociedade contemporânea ${ }^{193}$, em que o comércio, as comunicações e a vida humana de uma maneira geral teimam em não respeitar fronteiras histórica e politicamente construídas.

O Direito Internacional Privado cuida, sobretudo, das relações privadas internacionais ${ }^{194}$, e é contraproducente introduzir em seu seio grandes questões políticas. Deve-se, ao revés, atentar para as exigências da vida internacional do ser humano, bem como para o modo adequado de supri-las. Não nos parece que a questão central possa ser a soberania - dificilmente a soberania de um Estado seria atingida pela resolução de um caso transnacional entre particulares de acordo com outro direito.

Ademais, a visão de que nossa disciplina deve ser, sobretudo, um direito voltado para a vida dos seres humanos, e não um direito de mediação entre soberanias ou de repartição de competências (salvo indiretamente), reflete o parâmetro cosmopolita de que o indivíduo deve ser a unidade fundamental de consideração moral (veja-se o item I.2.5.2, supra). Assim, privilegia-se o tratamento adequado dos indivíduos, sendo os Estados e comunidades políticas vistos como instrumentos.

\footnotetext{
192 SAVIGNY, Friedrich Carl Von. Op. cit.. §348, p. 50.

${ }^{193}$ Veja-se, nesse sentido, CASELLA, Paulo Borba. Direito Internacional dos Espaços, São Paulo: Atlas, 2009, pp. 43-83. O autor remete à constatação de Edward McWhinney (MCWHINNEY, Self-determination of peoples and plural-ethnic states (secession and state succession and the alternative federal option, Recueil des Cours, v. 294, 2002, pp. 167-264).

${ }^{194}$ Como afirma Antonio Boggiano, "o Direito Internacional Privado é o sistema normativo destinado a realizar as soluções justas dos casos jusprivatistas multinacionais no âmbito de uma jurisdição estatal, de uma pluralidade de jurisdições estatais ou de uma jurisdição internacional" (BOGGIANO, Antonio. Curso de Derecho Internacional Privado - Derecho de las Relaciones Privadas Internacionales, Buenos Aires: Abeledo-Perrot, 2003, p. 19. Tradução livre.).
} 


\section{MULTILATERALISMO, UNILATERALISMO E MATERIALISMO}

Às duas grandes abordagens (conflito entre soberanias ou localização da relação jurídica), relacionam-se três métodos para a determinação da lei aplicável: o multilateralismo, o unilateralismo e o materialismo ${ }^{195}$.

O método multilateralista, inaugurado por Savigny, consiste, em linhas gerais, na busca da lei aplicável conforme a proximidade desta com os fatos. Por meio de regras de conexão, dispositivos indiretos que determinam o elemento de conexão a ser observado, e com o auxílio de princípios (princípio da proximidade, ordem pública, vedação à fraude à lei etc), busca-se o ordenamento jurídico mais apto a reger a questão, a partir dos dados do caso concreto.

O unilateralismo, por sua vez, apesar de também ter em vista, em última análise, a lei aplicável aos fatos, visa determiná-la a partir da verificação do âmbito de incidência relativo das leis concorrentes. Sobretudo, há preocupação em definir a extensão da aplicabilidade do direito do foro. O unilateralismo remete ao método estatutário, predominante na Europa do séc. XIII ao XVIII, bem como a algumas das principais teorias norte-americanas do séc. XX (como a teoria dos interesses governamentais de Brainerd Currie e a teoria do comparative impairment de William Baxter).

Por fim, o materialismo caracteriza-se pela preocupação direta com as normas e/ou princípios de direito substantivo que devem reger os casos transnacionais. Em primeiro lugar, essa normatização material pode assumir a forma internacional, mediante a celebração de tratados uniformizadores (direito uniformizado, utilizando a expressão de Dolinger ${ }^{196}$ ) e/ou a observância de costumes internacionais (destacando-se a ideia de lex mercatoria presente no Direito do Comércio Internacional).

Mas é possível, também, que o materialismo assuma um viés unilateralista. Dois exemplos são esclarecedores: o primeiro é o ius gentium do direito romano - direito

\footnotetext{
${ }^{195}$ Multilateralismo (ou bilateralismo) e unilateralismo na determinação da lei aplicável não devem ser confundidos com os conceitos de multilateralismo, bilateralismo e unilateralismo próprios das relações internacionais, que dizem respeito aos foros de discussão e negociação da política internacional. Trata-se de ideias completamente distintas. Sobre a contraposição entre multilateralismo e unilateralismo no Direito Internacional Privado, veja-se DOLINGER, Jacob. Direito Internacional Privado - Parte Geral. Rio de Janeiro: Forense, $10^{\mathrm{a}}$ ed., 2011, pp. 31-32.

${ }^{196}$ DOLINGER, Jacob. Direito Internacional Privado - Parte Geral. Rio de Janeiro: Forense, $10^{\text {a }}$ ed., 2011, p. 164.
} 
material especialmente criado pelo praetor peregrinus para reger relações envolvendo não cidadãos; o segundo é o better-law approach proposto por autores estadunidenses do séc. $\mathrm{XX}$, que propõe que o juiz aplique a lei por ele considerada mais justa ou de melhor qualidade $^{197}$. Note-se que o materialismo de caráter supranacional foge ao escopo principal do presente estudo, que aborda a articulação horizontal. Desse modo, daremos especial atenção ao materialismo unilateralista.

Em seguida, analisaremos esses três vieses metodológicos - multilateralismo, unilateralismo e materialismo - e suas implicações sobre a determinação da lei aplicável, de modo mais detalhado.

\subsection{Multilateralismo}

Savigny inaugurou o método multilateralista no volume VIII de sua obra Sistema do Direito Romano Atual (System des Heutigen Römischen Rechts), publicada em 1849. Nela, pregou a determinação, para cada classe de relações jurídicas, de sua sede ${ }^{198}$. Para ele, a questão relativa aos limites do domínio das normas e às dificuldades encontradas na demarcação desses limites seria meramente derivada, subordinada ao verdadeiro problema $^{199}$. A preocupação central de Savigny era a uniformidade de decisões, independentemente do país em que a sentença fosse proferida ${ }^{200}$. Seu princípio subjacente era a comunidade de direito entre os povos ${ }^{201}$.

Desse modo, o jurista alemão propôs diversos elementos de conexão, sendo o principal deles o domicílio. Admitiu, porém, diversos outros, tais como a lex rei sitae para as coisas, o locus regit actum para a forma dos atos jurídicos, a lex fori para matéria processual etc ${ }^{202}$. Segundo Savigny, haveria apenas duas exceções ao princípio da

\footnotetext{
${ }^{197}$ A aplicação do melhor direito material é um dos fatores de escolha propostos por Robert Leflar, em sua teoria eclética (veja-se LEFLAR, Robert. Conflicts Law: more on choice-influencing considerations, California Law Review, vol. 54, $\mathrm{n}^{\circ}$ 4, 1966, pp. 1584-1587) e o ponto principal da teoria de Friedrich Juenger, que propõe um "processo de escolha baseado na avaliação qualitativa das regras de decisão conflitantes" (JUENGER, Op. cit., p. 236).

${ }^{198}$ SAVIGNY, Friedrich Carl Von. Op. cit.. §348, p. 50.

${ }^{199}$ Idem, 344, p. 30.

${ }^{200}$ Ibidem, $\$ 348$, p. 50.

${ }^{201}$ Idem.

${ }^{202}$ Ibidem, §361, pp. 119-127.
} 
comunidade de direito entre os povos: as leis de natureza rigorosamente positiva ${ }^{203}$ e as instituições jurídicas não reconhecidas pelo foro (a exemplo da morte civil ou da escravidão, em Estados que não as reconheciam) ${ }^{204}$.

Assim se desenhou a estrutura das regras de conexão multilaterais (ou bilaterais): qualificação da relação jurídica em questão, seguida de sua localização por meio de um fator de conexão, conduzindo à lei aplicável, que pode ser tanto uma lei estrangeira como a lei do foro $^{205}$.

Diante do enfoque dominante das doutrinas estatutárias, que partiam da lei do foro para determinar seu âmbito de aplicação no espaço, Savigny resolve principiar pela relação jurídica para, conforme sua natureza, determinar sua sede, i.e., localizá-la em um ordenamento determinado ${ }^{206}$.

Note-se que essa "virada copérnica" empreendida por Savigny pode ser relacionada ao requisito cosmopolita de tratamento do indivíduo como unidade fundamental de consideração moral - é sintomático que o autor tenha afirmado que o problema relativo aos limites do domínio das normas, e às dificuldades encontradas na demarcação desses limites, é apenas uma questão derivada, subordinada ao verdadeiro problema do método ${ }^{207}$. Assim, similarmente à fórmula de Ulpiano, o que o método multilateralista busca é dar a cada um, ou a cada relação jurídica, o tratamento que lhe é devido.

Como bem observa Audit, a maior parte das codificações adotadas a partir do séc. XIX, até nossos dias, expressa-se na forma de regras de conexão multilaterais ${ }^{208}$. Assim o é, por exemplo, no Brasil ${ }^{209}$, na Índia ${ }^{210}$ e na União Europeia ${ }^{211}$. Do mesmo modo, as

\footnotetext{
${ }^{203}$ Savigny alerta que as leis de natureza rigorosamente positivas de que ele trata não devem ser confundidas com as normas não supletivas, na medida em que aquele conceito é mais restrito que este. As leis de natureza rigorosamente positivas savignianas são normas que não se prestam ao princípio da comunidade de direito entre os povos, e que podem ter por base um motivo moral ou de interesse geral - de caráter político, de ordem pública ou de economia política (SAVIGNY, Friedrich Carl Von. Op. cit.. §349, pp. 53-56).

${ }^{204}$ Idem.

${ }^{205}$ AUDIT, Bernard. Op. cit., p. 214.

206 FÉRnANDEZ ROZAS, José Carlos; LORENZO, Sixto Sánchez. Derecho Internacional Privado. Madrid: Thomsom Civitas, 2004, $3^{\text {a }}$ ed., pp. 115-116.

${ }^{207}$ SAVIGNY, Friedrich Carl Von. Op. cit.. $\$ 344$, p. 30.

${ }^{208}$ AUDIT, Bernard. Op. cit., p. 219.

${ }^{209}$ Cf. a Lei de Introdução às Normas do Direito Brasileiro, arts. $7^{\circ}$ a 17 (Decreto-Lei $n^{\circ} 4.657$, de 4 de setembro de 1942, conforme alterado).

${ }^{210}$ AGRAWAL, K. B.; SINGH, Vandana. Private International Law in India. Holanda: Kluwer Law International, 2010, p. 66.

${ }^{211}$ Veja-se, por sua importância, o Regulamento "Roma I" sobre lei aplicável a obrigações contratuais (Reg. (EC) $n^{\circ} 593 / 2008$ do Parlamento Europeu e do Conselho, de 17 de junho de 2008), especialmente art. $4^{\circ}$ e ss.
} 
Convenções da Haia sobre lei aplicável ${ }^{212}$, bem como as CIDIPs (Convenções Interamericanas de Direito Internacional Privado) ${ }^{213}$ utilizam-se, como estrutura principal, de regras de conexão multilaterais.

A recente lei chinesa de Direito Internacional Privado, vigente desde $1^{\circ}$ de abril de $2011^{214}$, também adota o multilateralismo. Em especial, seu art. $1^{\circ}$ estatui que tal diploma objetiva "especificar as leis aplicáveis às relações civis internacionais, resolvendo as disputas civis internacionais de modo justo e salvaguardando os direitos e interesses legítimos das partes". Em seguida, a lei chinesa estabelece uma série de regras de conexão multilaterais para cada matéria.

Registre-se que, desde a obra de Savigny, a teoria geral do Direito Internacional Privado desenvolveu-se consideravelmente. Já no fim do séc. XIX, descobriu-se o problema dos conflitos de sistemas, subjacente ao método multilateralista. Sendo as regras de conexão predominantemente internas; os critérios para sua aplicação, bem como a opção por um ou outro elemento de conexão, variam de um país para outro, o que traz dificuldades de coordenação.

Desse modo, as regras de conexão rígidas mostraram-se insuficientes quando os sistemas domésticos envolvidos classificam a mesma questão em categorias diferentes (problema do conflito de qualificações) ${ }^{215}$. Da mesma forma, quando o direito aplicável possui uma regra de conexão diferente daquela utilizada pelo foro, pergunta-se se tal regra deve ou não ser considerada (problema do reenvio) ${ }^{216}$. Por último, resta saber se a disputa pode ser decidida, em seus diferentes aspectos, por mais de um direito (problemas do depeçage e da questão prévia).

\footnotetext{
${ }^{212}$ Veja-se, por exemplo, o Protocolo sobre lei aplicável a obrigações alimentares, firmado em $23 \mathrm{de}$ novembro de 2007, especialmente art. $3^{\circ}$.

${ }^{213}$ Veja-se, por exemplo, a Convenção Interamericana sobre Normas Gerais de Direito Internacional Privado, firmada em 8 de maio de 1979 (vigente no Brasil por força do Decreto ${ }^{\circ} 1.979$, de 9 de agosto de 1996), art. $1^{\circ}$ e ss.

${ }^{214}$ Lei da República Popular da China sobre Leis Aplicáveis a Relações Civis Internacionais, adotada em 28 de outubro de 2010 e promulgada pelo Decreto do Presidente da República Popular da China n ${ }^{\circ} 36$ (tradução para o inglês feita por Lu Song, disponível em: http://conflictoflaws.net/News/2011/01/PIL-China.pdf, acessado em 21.06.2011). Tradução livre para o português.

${ }^{215}$ A descoberta dos conflitos de qualificações é atribuída às obras de Franz Kahn (KAHN, Franz. Jhering's Jahrbücher 1, 1891) e Etienne Bartin (BARTIN, Etienne, De l'impossibilité d'arriver à la supression définitive des conflits des lois, Journal de Droit International Privé, 1897). Veja-se RIGAUX, François. La théorie des qualifications en droit international privé. Bruxelas: F. Larcier, 1956.

${ }^{216} \mathrm{O}$ problema do reenvio remete ao caso Forgo (julgamentos da Corte de Cassação francesa de 24 de junho de 1878 e de 22 de fevereiro de 1882).
} 
Nesse contexto, foi engendrada uma espécie de "tecnologia da regra de conexão" uma ciência formal caracterizada, em alguma medida, por enxergar a regra como um fim em si mesma ${ }^{217}$. Outra visão é a de que os princípios desenvolvidos no contexto dessa dita "tecnologia" podem ser vistos enquanto formas de se evitar que a rigidez das regras de conexão cause problemas, seja em nível local ou internacional ${ }^{218}$. Não obstante, ao longo do séc. XX houve diversas reações contra o formalismo do método tradicional, reações essas que oscilaram entre um retorno ao unilateralismo, o materialismo e a flexibilização do próprio método multilateralista (princípio da proximidade).

\subsection{Unilateralismo}

A origem da abordagem unilateralista remete-nos ao método estatutário, o qual consistia, em linhas gerais, em determinar o campo de aplicação dos estatutos (leis locais das Cidades-Estados do norte da Itália) e, posteriormente, dos costumes e leis das províncias da França e dos Países Baixos, em função de seu objeto e, portanto, do exame de seu conteúdo ${ }^{219}$.

A teoria estatutária classificava, no início, os estatutos em duas grandes categorias os estatutos reais, de aplicação territorial (ex.: dispositivos versando a forma dos atos, a conclusão dos contratos, os atos ilícitos etc) e os estatutos pessoais, de aplicação extraterritorial (ex.: dispositivos sobre estado e capacidade da pessoa, regimes matrimoniais etc). Posteriormente, surgiu a ideia de estatutos contratuais, submetidos ao princípio da autonomia da vontade das partes quanto à eleição da lei aplicável (escolha esta que poderia ser expressa ou tácita) ${ }^{220}$.

Na segunda metade do séc. XII, Aldricus propôs a aplicação do costume "melhor e mais útil" (quae potior et utilior videtur) - discute-se se isso significaria o direito mais

${ }^{217}$ VALLINDAS, P. G.. La structure de la règle de conflit. Recueil des Cours, v. 101, 1960, p. 327, apud AUDIT, Bernard. Op. cit., p. 230.

${ }^{218}$ DOLINGER, Jacob. In defense of the "General Part" principles. In: BORCHERS, Patrick; ZEKOLL, Joachim (ed.). International Conflicts of Laws for the Third Millenium: Essays in honor of Friedrich Juenger. Nova York: Transnational Publishers, 2000, p. 24.

${ }^{219}$ AUDIT, Bernard. Op. cit., p. 150.

${ }^{220}$ Idem, p. 158. 
justo ou aquele que possuísse maior conexão com o objeto da lide ${ }^{221}$. Já Accursius inseriu uma famosa glosa no Código de Justiniano, afirmando que um bolonhês acionado em Módena não deveria ser julgado conforme os estatutos de Módena, aos quais não estava submetido (statutum non ligat nisi subditos) ${ }^{222}$.

Mas foi o pós-glosador italiano Bártolo de Sassoferato (1314-1357) que efetuou a distinção central entre estatutos pessoais e estatutos reais, a partir da interpretação dos próprios textos legais, a qual teve enorme influência sobre a teoria estatutária a partir de então ${ }^{223}$. Com efeito, suas soluções chegaram até nossos dias ${ }^{224}$.

Assim é que o Código Bustamante, vigente no Brasil por força do Decreto $n^{\circ}$ 18.871, de 13 de agosto de 1929, utiliza-se do método estatutário em seus artigos $3^{\circ}$ ao $5^{\circ}$, ao propor a classificação das leis conforme seu conteúdo ${ }^{225}$ :

"Art. $3^{\circ}$ - Para o exercício dos direitos civis e para o gozo das garantias individuais idênticas, as leis e regras vigentes em cada Estado contratante consideram-se divididas nas três categorias seguintes:

I. As que se aplicam a pessoas em virtude do seu domicílio ou da sua nacionalidade e as seguem, ainda que se mudem para outro país, denominadas pessoais ou de ordem pública interna;

II. As que obrigam por igual a todos os que residem no território, sejam ou não nacionais, - denominadas territoriais, locais ou de ordem pública internacional;

\footnotetext{
${ }^{221}$ Enquanto Max Gutzwiller interpretou que o melhor direito, para Aldricus, seria aquele que possui conexão mais íntima com o caso a ser julgado, Martin Wolff entendeu que o magistrado de Bolonha se referia à qualidade da lei em si (respectivamente: GUTZWILLER, Max. Le développement historique du Droit International Privé, Recueil des Cours, v. 29, 1929, p. 301; WOLLF, Martin. Derecho Internacional Privado, trad. p/ o espanhol de A. M. López. Barcelona: Bosch, 1958, p. 22). Sobre a discussão, veja-se DOLINGER, Jacob. Contratos e obrigações no Direito Internacional Privado. Rio de Janeiro: Renovar, 2007, pp. 271-273; e BASSO, Maristela. Op. cit., p. 108.

${ }^{222}$ A glosa foi acrescida ao título primeiro do Livro I do Codex, integrante do Corpus Juris de Justiniano. O trecho comentado inicia com "cunctos populos quos clementiae nostrae regit temperamentum" e impunha a religião católica aos povos governados pelo imperador romano. Segundo Werner Goldschmidt, tal glosa foi aposta por volta do ano de 1228 (GOLDSCHMIDT, Werner. Op. cit., p. 165).

${ }^{223}$ DOLINGER, Jacob. Direito Internacional Privado - Parte Geral. Rio de Janeiro: Forense, 2011, 10 a ed., p. 187.

${ }^{224}$ Idem.

${ }^{225}$ Veja-se: AUDIT, Bernard. Op. cit., p. 160.
} 
III. As que se aplicam somente mediante a expressão, a interpretação ou a presunção da vontade das partes ou de alguma delas, denominadas voluntárias, supletórias ou de ordem privada.

Art. $4^{\circ}$ - Os preceitos constitucionais são de ordem pública internacional.

Art. $5^{\circ}$ - Todas as regras de proteção individual e coletiva, estabelecidas pelo direito político e pelo administrativo, são também de ordem pública internacional, salvo o caso de que nelas expressamente se disponha o contrário."

Observe-se, todavia, que em outros dispositivos o Código Bustamante mais se aproxima ao método multilateralista, como por exemplo em seu art. $7^{\circ}$, que estabelece:

\footnotetext{
"Art. $7^{\circ}$ - Cada Estado contratante aplicará como leis pessoais as do domicílio, as da nacionalidade ou as que tenha adotado ou adote no futuro a sua legislação interna."
}

O método unilateralista, de classificar as leis e costumes segundo seu objeto, marcou a obra de todos os grandes estatutários a partir de Bártolo, destacando-se o também italiano Baldo (1327-1400), os franceses Charles Dumoulin (1500-1566) e Bernard D’Argentré (1519-1590) e o holandês Ulrich Huber, já mencionado. Dumoulin notabilizou-se por delinear a teoria da autonomia da vontade no Direito Internacional Privado, criando a ideia de estatutos cuja aplicação estaria sujeita à vontade das partes. Já D’Argentré e Huber proferiram doutrinas marcadas por forte territorialismo.

Ao debaterem se os estatutos locais podiam ou não ser aplicados a pessoas no exterior e se os estrangeiros dentro do território estavam ou não vinculados às leis deste último, tais autores foram ao encontro da estrutura das chamadas normas unilaterais, que almejam determinar o âmbito de aplicação das leis concorrentes ${ }^{226}$. Eis o caráter unilateralista do método estatutário.

${ }^{226}$ JUENGER, Friedrich. Op. cit., p. 13. 
Exemplos mais recentes de unilateralismo são as teorias norte-americanas que surgiram no séc. XX, por influência direta da escola realista de Yale (em que pontificaram Cook, Lorenzen e Yntema, dentre outros) ${ }^{227}$.

Cook entendia que os princípios e regras do conflito de leis deveriam ser vistos como ferramentas de trabalho, e não pervertidos em um uso aparentemente mecânico, que esconde as razões verdadeiras da decisão ${ }^{228}$. Já Lorenzen escreveu que o único modo de progredir seria enfrentar o fato de que a escolha de uma ou outra regra de conexão depende exclusivamente de considerações políticas do Estado ${ }^{229}$. Para Lorenzen, as soluções $a$ priori obrigam o Estado a aceitar um sacrifício de suas políticas locais sem que ganhe benefício correspondente em termos de uniformização ${ }^{230}$. Assim, o método indutivo seria uma alternativa melhor, devendo-se deixar ao juiz a resolução do problema do conflito de leis. De modo similar, Yntema criticou frontalmente a vested rights theory de Beale e Goodrich, por ser demasiadamente generalista, e propôs que se desse mais atenção aos problemas ligados à administração da justiça ${ }^{231}$.

A partir dessas ideias, David Cavers, de Harvard, também criticou o método tradicional, defendendo que as cortes não deveriam simplesmente escolher um ordenamento (“jurisdiction selecting”), sem que antes verificassem a solução final à qual ele levaria - a tarefa do juiz seria, sobretudo, alcançar uma solução final justa para o caso $^{232}$. Cavers alertou, ainda, para a existência de falsos conflitos, uma vez que frequentemente as leis em conflito não têm por objetivo proteger os mesmos interesses ${ }^{233}$. $\mathrm{O}$ autor sistematizou sua teoria propondo uma série de princípios de preferência para decidir entre as políticas subjacentes aos direitos em conflito, de modo a alcançar a solução final mais justa ${ }^{234}$.

${ }^{227}$ Sobre a escola realista de Yale, veja-se NAZO, Nicolau. Objeto e método do Direito Internacional Privado, São Paulo: Acervo do Departamento de Direito Internacional da FDUSP, 1952, pp. 50-59; e JUENGER, Friedrich. Op. cit., p. 92.

${ }^{228}$ COOK, Walter W. The logical and legal bases of the Conflict of Laws, Yale Law Journal, v. 33, $\mathrm{n}^{\circ}$ 5, 1923, pp. 457-488.

${ }^{229}$ LORENZEN, Ernest G.. Territoriality, public policy and the Conflict of Laws, Yale Law Journal, v. 33, n 7,1923, p. 745.

${ }^{230}$ Idem, p. 751.

${ }^{231}$ YNTEMA, Hessel E. The hornbook method and the Conflict of Laws, Yale Law Journal, v. 37, $\mathrm{n}^{\circ} 4$, 1928, pp. 482-483.

${ }^{232}$ CAVERS, David F. A critique of the choice of law problem, Harvard Law Review, v. 47, n 2, 1933, pp. 173-208.

${ }^{233}$ Idem.

${ }^{234}$ CAVERS, David F. The choice of law process. Ann Arbor: University of Michigan Press, 1965. 
Note-se que, como já afirmado ${ }^{235}$, essa busca pela justiça material a todo custo pode mascarar o provincianismo, por meio de uma tendenciosidade à aplicação desmedida da lex fori, visto que esta costuma ser mais próxima à concepção particular de justiça do julgador. De fato, o próprio Cavers admitiu que "a aplicação de regras mecânicas pode ser

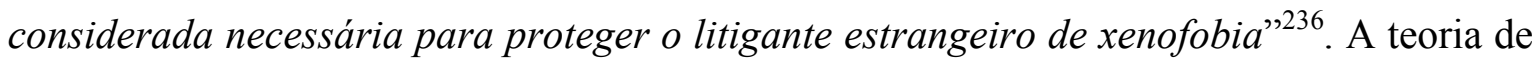
Cavers expressa tanto a ótica unilateralista quando a ótica materialista, que será abordada adiante $^{237}$. Em verdade, diga-se, unilateralismo e materialismo estão frequentemente relacionados.

Mas o ápice do unilateralismo norte-americano foi a teoria dos interesses governamentais de Brainerd Currie. Para Currie, se apenas um Estado possui interesse (tratando-se, portanto, de um falso conflito), a lei desse Estado deve ser aplicada. Se uma corte for chamada a aplicar um direito estrangeiro, ela deve determinar se é razoável, analisando as políticas subjacentes às leis, que o Estado em questão tenha sua política atendida $^{238}$. Se a corte observar que parece haver um conflito, ela deve reinterpretar as políticas de modo restrito, moderado, de forma a evitá-1o ${ }^{239}$. Se o conflito for mesmo inevitável, o autor propõe que se aplique a lei do foro, visto que as cortes não possuiriam, para ele, aptidão para ponderar interesses governamentais distintos ${ }^{240}$.

Como se pode facilmente notar, a abordagem de Currie é marcada por um provincianismo inescusável, em que se evita ao máximo a aplicação de qualquer direito estrangeiro, com vistas a perseguir unilateralmente os interesses do foro. A imparcialidade cosmopolita é por ele completamente negligenciada, na medida em que trata o Judiciário como uma simples longa manus em busca do cumprimento dos interesses políticos do foro. Outra crítica pertinente é a de que, mesmo que se aceitasse a teoria dos interesses governamentais, a concepção de Currie acerca desses interesses é estreita e provinciana, porquanto, para além de seus objetivos egoísticos de curto prazo, os Estados também

\footnotetext{
${ }^{235}$ Veja-se o item II.3, supra.

${ }^{236}$ CAVERS, David F. A critique of the choice of law problem, Harvard Law Review, v. 47, $\mathrm{n}^{\circ} 2,1933, \mathrm{p}$. 203.

${ }^{237}$ Veja-se o item III.2.3, infra.

${ }^{238}$ CURRIE, Brainerd. Selected essays on the Conflict of Laws. Durham: Duke University Press, 1963, p. 119 .

${ }^{239}$ Idem.

${ }^{240}$ Ibidem.
} 
possuem interesse em integrar um sistema mundial de regulação transnacional e afiliações comunitárias múltiplas, como aponta Berman ${ }^{241}$.

Já William Baxter, que desenvolveu a teoria de Currie, acreditava que as cortes possuiriam condições de decidir entre os interesses governamentais em jogo. Para o autor, dever-se-ia aplicar o direito que sofreria maior prejuízo caso não fosse aplicado, após uma análise comparativa (comparative impairment) ${ }^{242}$.

Como se sabe, a teoria dos interesses governamentais foi incorporada ao Restatement Second of the Conflict of Laws, compilação norte-americana de princípios e parâmetros a serem utilizados em nossa matéria, publicada em 1971 pelo American Law Institute. Especificamente, a Seção 6 do Restatement, em sua subseção 2, recomenda que, dentre outros fatores a serem considerados na determinação da lei aplicável, atente-se para as opções políticas (policies) relevantes do foro e para as opções políticas de outros Estados interessados, bem como para os interesses relativos desses Estados na resolução da lide.

Outro autor que levou o unilateralismo ao extremo foi Albert Ehrenzweig, que chegou a propor que a aplicação da lex fori deveria ser a grande regra geral, tanto em casos interestaduais quanto em casos internacionais ${ }^{243}$. Para ele, a autonomia da vontade, por ser uma exceção já cristalizada, poderia ser considerada uma segunda regra básica; ao passo que outros elementos de conexão (tais como a lex loci delicti ou a lex situs) só deveriam ser aplicados em casos verdadeiramente excepcionais ${ }^{244}$. Desse modo, a disciplina poderia se concentrar naquilo que, para ele, deveria ser sua preocupação fundamental: as questões de jurisdição internacional e, particularmente, a doutrina do forum non conveniens ${ }^{245}$. Tal como a teoria de Currie, o lexforismo de Ehrenzweig também é extremamente provinciano, na medida em que ignora tanto os interesses quanto as perspectivas de outros povos, expressos em direitos estrangeiros.

${ }^{241}$ BERMAN, Paul S. Choice of law and jurisdiction on the Internet - Towards a cosmopolitan vision of Conflict of Laws: redefining governamental interests in a global era, The University of Pennsylvania Law Review, v. 153, 2005, pp. 1852.

${ }^{242}$ BAXTER, William F. Choice of Law and the Federal System, Stanford Law Review, vol. 16, $\mathrm{n}^{\circ} 1,1963$, pp. 1-42. Note-se que o artigo de Baxter concentra-se nos conflitos de leis no âmbito interno do Federalismo americano.

${ }^{243}$ EHRENZWEIG, Albert A. The Lex Fori - Basic rule in the Conflict of Laws, Michigan Law Review, vol. $58, \mathrm{n}^{\circ} 5,1960$, pp. 643-644.

${ }^{244}$ Idem, p. 644.

${ }^{245}$ Idem, p. 645. Veja-se, também: EHRENZWEIG, Albert A. A proper law in a proper forum: a Restatement of the "Lex Fori" approach, Oklahoma Law Review, n 18, 1965, p. 340. 
As teorias de Cavers, Currie, Baxter e Ehrenzweig são exemplos de unilateralismo, ao buscarem delimitar o âmbito relativo de incidência das leis em conflito. As teorias de Currie e Ehrenzweig foram o ápice da proposta unilateralista e, caso seguidas, levam à aplicação quase que exclusiva da lex fori. É exata a crítica de Haroldo Valladão, que classifica as doutrinas de Currie e Ehrenzweig como um "desesperado niilismo"246. Com efeito, em vez de buscarem reais soluções para os problemas e contradições do Direito Internacional Privado, as propostas dos dois autores simplesmente fogem do problema, ao proporem a aplicação indiscriminada da lex fori.

As teorias unilateralistas apresentam, ainda, problemas de ordem metodológica. Quando nenhum dos direitos em questão se considera aplicável (lacuna), bem como quando mais de um direito assim se reputa (acúmulo), os critérios unilateralistas mostramse flagrantemente insuficientes ${ }^{247}$. De fato, não há como decidir, nesses casos, com base na interpretação dos próprios direitos materiais, sem recorrer a um critério que lhes seja externo. A única alternativa que resta, então, para os casos de lacuna ou de acúmulo (ou “conflitos verdadeiros" - para utilizar a nomenclatura desses autores), é recorrer à simples aplicação da lex fori, o que revela o provincianismo por trás do unilateralismo.

O cerne da crítica a essa tendência provinciana pode ser resumido por meio de uma felicíssima frase, tomada emprestada de Hélène Gaudemet-Tallon (em outro contexto, diga-se):
"A vontade de aplicar sua própria lei, sem mesmo vislumbrar a possibilidade de aplicar uma lei estrangeira, parece-me a característica de uma ordem jurídica ainda imatura, que visa se impor de modo imperialista em vez de buscar uma boa coordenação internacional". 248

Perfeita a interpretação da autora. Note-se que, como afirma Berman, no contexto de um mundo fortemente interdependente, preocupações quanto a um imperialismo jurídico podem ser tão importantes quanto preocupações acerca do imperialismo cultural,

\footnotetext{
${ }^{246}$ VALLADÃO, Haroldo. Op. cit., p. 85.

${ }^{247}$ Em sentido próximo, AUDIT, Bernard. Op. cit., p. 243. Jacob Dolinger também se refere à lacuna e ao acúmulo, no contexto das regras de conexão unilaterais, que tão somente definem o âmbito de aplicação do próprio direito. Nesse caso, deve-se admitir sua bilateralização pelo intérprete. Do contrário, resultará lacuna ou acúmulo (DOLINGER, Jacob. Direito Internacional Privado - Parte Geral. Rio de Janeiro: Forense, 2011, 10a ed., pp. 214-216).

${ }^{248}$ GAUDEMET-TALLON, Hélène. Op. cit., p. 269. Tradução livre.
} 
político ou militar ${ }^{249}$. Assim é que o jurista bem intencionado e atento à complexidade do mundo contemporâneo deve buscar uma boa coordenação entre as diversas ordens jurídicas, evitando ao máximo a tendência provinciana de impor os próprios valores jurídicos em todos os casos.

Note-se que essas transformações pelas quais passou a teoria estadunidense do conflito de leis em meados do séc. XX, que ficaram conhecidas como "Revolução Americana", apesar de haverem sido permeadas por grandes equívocos metodológicos, tiveram o mérito de apontar falhas importantes do método tradicional, impulsionando a reflexão ao redor do mundo.

Mas, como observa Ralf Michaels ${ }^{250}$, a dita revolução envelheceu. O autor aponta, especialmente, para o fato de que novos desenvolvimentos podem ser obtidos no campo da interdisciplinaridade (destacando-se as contribuições da análise econômica do direito ${ }^{251}$, da Ciência Política - que aborda o problema da governança global, e das discussões sobre o pluralismo jurídico, presentes na Antropologia). Assim, seria possível elaborar regras melhores, levando a um novo Restatement para os Estados Unidos. Em outras palavras: ainda há esperança.

Nesse contexto, como já apontado ${ }^{252}, \operatorname{Berman}^{253}$ recentemente defendeu nos Estados Unidos uma abordagem "cosmopolita pluralista", devendo as cortes debater as afiliações comunitárias potencialmente relevantes e considerar sua importância relativa, antes de procederem à aplicação do direito material - é digno de nota que isso guarda semelhança com o que propõe o princípio da proximidade, conhecido há tempos em nossa disciplina ${ }^{254}$.

\footnotetext{
249 BERMAN, Paul S. Choice of law and jurisdiction on the Internet - Towards a cosmopolitan vision of Conflict of Laws: redefining governamental interests in a global era, The University of Pennsylvania Law Review, v. 153, 2005, p. 1880.

${ }^{250}$ MICHAELS, Ralf. After the Revolution - Decline and Return of U.S. Conflicts of Laws. Durham: Duke Law Faculty Scholarship, Paper 2129, 2009. Disponível em: http://scholarship.law.duke.edu/faculty_scholarship/2129, acessado em 28.06.2011.

${ }^{251}$ Para visões sobre o Direito Internacional Privado do ponto de vista do Law and Economics, vejam-se: GUZMAN, Andrew T. Choice of law: new foundations, Georgetown Law Journal, n 90, 2002, pp. 883940; e BASEDOW, Jürgen; KONO, Toshiyuki. An Economic Analysis of Private International, Tübingen: Mohr Siebeck, 2006.

${ }^{252}$ Veja-se o item II.2, supra.

253 BERMAN, Paul S. Conflict of Laws, Globalization and Cosmopolitan Pluralism, The Wayne Law Review, 51, pp. 1115-1145, 2005.

${ }^{254}$ Sobre o princípio da proximidade, veja-se o item III.2.4.1, infra.
} 


\subsection{Materialismo}

Como já afirmado, há duas possibilidades de materialismo (ou substancialismo) (i) um verdadeiramente internacional (celebração e cumprimento de tratados uniformizadores e/ou observância de costumes internacionais) ${ }^{255}$; e (ii) outro unilateralista, em que determinada jurisdição baseia-se em valores de direito material que the são próprios para cuidar das lides transfronteiriças. O presente estudo concentrar-se-á apenas nesse segundo tipo, na medida em que o que aqui nos interessa é a articulação horizontal entre os direitos dos diversos Estados.

A origem do materialismo remonta ao ius gentium romano. Por volta de 242 a.C., foi instituída em Roma a figura do praetor peregrinus, competente para julgar questões que envolvessem cidadãos de fora do império. Tal instituição passou, paulatinamente, a criar normas materiais específicas para governar tais relações - o ius gentium, normas essas diferentes daquelas existentes no ius civile, o qual regia as relações entre cidadãos romanos $^{256}$.

É interessante a observação de Haroldo Valladão, ao afirmar que o ius gentium, ao progredir, fazia-o de forma uniformizadora e supressora do ius peregrinum e do ius civile, confundindo os três em um único direito - o romano, traço peculiar do espírito imperialista de então ${ }^{257}$. Com efeito, a imposição unilateral dos próprios valores materiais a estrangeiros - ainda que adaptados, sob a forma de um direito especificamente criado pelo foro para reger as relações privadas transnacionais, não deixa de ser uma forma de imposição imperialista.

Um exemplo mais recente de materialismo é o better-law approach de alguns autores norte-americanos, que propõem a aplicação do melhor direito, i.e., daquele que é mais justo, de melhor qualidade. Esse método talvez não seja grande novidade, porquanto

255 A discussão se o fenômeno da uniformização do direito faz parte do Direito Internacional Privado, enquanto um de seus métodos, ou se, ao contrário, constitui sua negação, é o cerne da divergência entre as teorias de Jitta e Asser. Sobre essas duas visões distintas, veja-se: DOLINGER, Jacob. Direito Internacional Privado - Parte Geral. Rio de Janeiro: Forense, 2011, 10 a ed., pp. 167-168. Dolinger propõe uma visão conciliadora das duas teorias, a partir da interpretação de que Asser referia-se às regras de direito privado estritamente internas; ao passo que Jitta referir-se-ia à uniformização convencional de regras concernentes a relações de caráter internacional, como o comércio internacional.

256 JUENGER, Friedrich. Op. cit., pp. 8-9; VALLADÃO, Haroldo. Op. cit., pp. 24-25; DOLINGER, Jacob. Direito Internacional Privado - Parte Geral. Rio de Janeiro: Forense, 2011, $10^{\text {a }}$ ed., p. 181; BASSO, Maristela. Op. cit., p. 102-104.

${ }^{257}$ VALLADÃO, Haroldo. Op. cit., pp. 25. 
teria sido proposto pelo estatutário Aldricus, já no séc. XII, se admitirmos a interpretação que Martin Wolff deu ao famoso fragmento do primeiro ${ }^{258}$. Mas, no séc. XX, essa ideia foi defendida nos Estados Unidos, sobretudo nas obras de Robert Leflar e Friedrich Juenger.

Robert Leflar propôs cinco fatores a serem considerados pelo juiz na escolha do direito aplicável, a saber: (i) previsibilidade de resultados, (ii) preservação da ordem interestadual e da ordem internacional, (iii) simplificação da tarefa do juiz, (iv) perseguição dos interesses governamentais do foro; e (v) aplicação do melhor direito ${ }^{259}$. Este último fator traduz perfeitamente o materialismo, na medida em que envolve uma apreciação, por parte do juiz, a respeito da qualidade intrínseca das leis concorrentes, de modo a escolher aquela que seja, em sua opinião, superior, mais justa. Note-se que os dois primeiros fatores parecem mais ligados ao multilateralismo, ao passo que o quarto fator é autenticamente unilateralista, havendo, portanto, hesitação metodológica na proposta de Leflar.

Já na obra de Friedrich Juenger, o materialismo é o traço marcante. Após criticar frontalmente o multilateralismo, o autor propõe uma abordagem teleológica, voltada a resultados $^{260}$. Para ele, os juízes devem empreender um esforço consciente no sentido de aplicar as normas que são, em sua opinião, de qualidade superior, o que poderia levar, em última instância, a uma espécie de ius commune ${ }^{261}$.

Juenger admite que regras de conexão alternativas, materialmente orientadas, possam auxiliar o juiz em tal tarefa (ex.: regra do favor negotii, pela qual se aplica a lei mais favorável à validade formal do negócio jurídico), porém relembra que o Direito Internacional Privado é uma área em que juízes e doutrinadores têm mais importância que o legislador ${ }^{262}$. Assim, para o autor, o ativismo judicial seria preferível à utilização de regras de conexão temperadas por aquilo que, em seu entender, não passaria de meros subterfúgios - os princípios da "Parte Geral" da matéria ${ }^{263}$.

\footnotetext{
258 A respeito de Aldricus, veja-se o item II.2.2, supra. Outra interpretação, como já mencionado anteriormente, é a de que Aldricus referia-se não à lei de melhor qualidade, mas sim à lei mais proximamente conectada com a lide (esta é a interpretação dada por Gutzwiller).

${ }^{259}$ LEFLAR, Robert A. Conflicts Laws: more on choice-influencing considerations, California Law Review, vol. 54, n 4, 1966, pp. 1586-1587.

260 JUENGER, Friedrich. Op. cit., pp. 191-199.

${ }^{261}$ Idem, p. 193.

262 Ibidem, p. 198.

${ }^{263}$ Idem, p. 199.
} 
Dolinger $^{264}$, ao criticar a obra de Juenger, afirma que o multilateralismo nunca foi desprovido de valores, pois reflete a tolerância, o entendimento, a cooperação mútua e, acima de tudo, a busca pela lei mais apropriada. Mesmo quando o foro limita esse ideal em razão de sua própria segurança, estamos novamente diante de um valor. Desse modo, haveria uma ponderação de valores e princípios, complexa - é verdade, porém interessante e recompensadora.

Obviamente, ao seguir o método materialista, o juiz tenderá a aplicar a lei do foro, uma vez que esta é mais próxima a seus valores e é aquela com a qual ele está mais acostumado. Nesse sentido, o direito do foro será frequentemente considerado superior. Com efeito, as diferenças filosóficas entre os direitos materiais dos diversos países fazem com que a solução de um caso, em regra, não possa se dar mediante a busca da lei materialmente mais justa ${ }^{265}$. Mesmo que seja elaborada uma solução ad hoc, como parece sugerir Juenger, tal solução estará frequentemente imbuída de valores pertencentes ao foro e, por vezes, alheios às especificidades dos direitos estrangeiros envolvidos.

Essa tendenciosidade faz com que o materialismo afaste o intérprete da exigência de imparcialidade da justiça cosmopolita, a qual impõe equidistância em relação às perspectivas nacionais parciais, devendo o intérprete despir-se de preconceitos, na maior medida possível. Em outras palavras: o materialismo tende ao provincianismo. É preciso estar aberto, em regra, para compreender e aceitar valores diferentes dos próprios, em autêntico espírito pluralista, na busca pelo ideal de justiça. Não é tarefa das mais fáceis, e a boa prudência indica que atalhos milagrosos devem ser evitados.

${ }^{264}$ DOLINGER, Jacob. In defense of the “General Part” principles. In: BORCHERS, Patrick; ZEKOLL, Joachim (ed.). International Conflicts of Laws for the Third Millenium: Essays in honor of Friedrich Juenger. Nova York: Transnational Publishers, 2000, p. 35.

${ }^{265}$ BOGGIANO, Antonio. Op. cit., p. 69. O autor faz referência à lição de Hubert Bauer. 


\subsection{Pluralismo de métodos}

Observe-se que multilateralismo, unilateralismo e materialismo não são necessariamente mutuamente excludentes. Batiffol, já em 1973, observou a possibilidade de um pluralismo de métodos no Direito Internacional Privado ${ }^{266}$.

Mesmo nos sistemas multilateralistas, é possível encontrar algumas regras de conexão unilaterais, não passíveis de bilateralização. No Direito Internacional Privado brasileiro, encontra-se um exemplo no art. $7, \S 1^{\circ}$, da Lei de Introdução às Normas do Direito Brasileiro $^{267}$ :

“§1 A sucessão de bens de estrangeiros, situados no País, será regulada pela lei brasileira em benefício do cônjuge ou dos filhos brasileiros, ou de quem os represente, sempre que não lhes seja mais favorável a lei pessoal do de cujus."

Note-se que, se é certo que a literalidade do dispositivo preocupa-se com a extensão da aplicação da lei do foro, ademais só cuidando de bens situados no Brasil e de cônjuge e filhos brasileiros (não sendo possível bilateralizá-lo por meio de interpretação) - aspecto unilateralista, a regra possui, por outro lado, natureza materialista, pois tem por objetivo a aplicação da lei mais favorável a determinadas partes. Para se desvendar qual é essa lei, será preciso perquirir o conteúdo dos direitos materiais em conflito. Desse modo, a regra representa uma infiltração do unilateralismo e do materialismo no sistema brasileiro de Direito Internacional Privado, que possui matriz multilateralista savigniana.

Registre-se que o parágrafo em questão praticamente reproduz o art. $5^{\circ}, \mathrm{XXXI}$, da Constituição brasileira, o qual estatui que " a sucessão de bens de estrangeiros situados no País será regulada pela lei brasileira em beneficio do cônjuge ou dos filhos brasileiros, sempre que não lhes seja mais favorável a lei pessoal do 'de cujus'".

$\mathrm{O}$ art. $10, \S 1^{\circ}$, da Lei de Introdução e o art. $5^{\circ}$, XXXI, da Constituição brasileira são nitidamente discriminatórios em relação a herdeiros estrangeiros; os quais, por força de tais

${ }^{266}$ BATIFFOL, Henri. Le pluralisme des méthodes em droit international privé, Recueil des Cours, v. 139, Leiden/Boston: Martinus Nijhoff Publishers, 1973, pp. 75-147.

${ }^{267}$ Decreto-Lei $\mathrm{n}^{\circ} 4.657$, de 4 de setembro de 1942 , conforme alterado. 
normas, gozam de status inferior em comparação a cônjuge e filhos nacionais. Os dispositivos sofrem de provincianismo, ferindo a exigência cosmopolita de imparcialidade em relação à nacionalidade das pessoas: o cônjuge ou filho é beneficiado economicamente pela lei, em detrimento dos demais herdeiros, pelo simples fato de ser nacional brasileiro.

O mais grave é que, encontrando-se tal regra inscrita no rol de direitos fundamentais do art. $5^{\circ}$ da Constituição, ela é reputada cláusula pétrea, não passível de modificação nem mesmo por meio de Emenda Constitucional, nos termos do art. $60, \S 4^{\circ}$, III, da Constituição. Desse modo, apenas uma revolução seria capaz de eliminá-la do ordenamento brasileiro $^{268}$.

Aponte-se para o fato de que as regras verdadeiramente unilaterais (i.e., aquelas que não são passíveis de interpretação que as bilateralize) não são regras de conexão no sentido tradicional, as quais supõem uma verdadeira escolha entre as normas em tela, de uma perspectiva igualitária ${ }^{269}$. São, diferentemente, regras que definem o âmbito de aplicação da lei do foro, muitas vezes de índole protetiva - dizendo respeito à proteção de partes hipossuficientes. Em certos casos, porém, apresentam viés discriminatório, como ocorre com o art. $10, \S 1^{\circ}$, da Lei de Introdução e o art. $5^{\circ}$, XXXI, da Constituição brasileira.

Ademais, do ponto de vista histórico, o multilateralismo sofreu modificações por influência das teorias norte-americanas do séc. XX, observando-se a emergência de três fenômenos: (i) a flexibilização das regras de conexão, por meio do princípio da proximidade; (ii) a redescoberta, por parte da doutrina, das normas de aplicação necessária ou imediata (lois de police); e (iii) uma maior influência de preocupações materialistas em geral, com o fortalecimento de algumas regras de conexão ditas substanciais ${ }^{270}$. Conforme aponta Nadia de Araujo, "não houve abandono do método conflitual tradicional, mas um

\footnotetext{
${ }^{268}$ Esta inteligente observação foi feita pelo Professor Gustavo Ferraz de Campos Monaco, durante o exame de qualificação do projeto desta dissertação, ocorrido em 09.11.2011.

269 AUDIT, Bernard. Op. cit., p. 264.

270 Sobre essas tendências, veja-se: RAMOS, Rui Manuel de Moura. Perspectiva do Direito Internacional Privado no limiar do novo século. In: DIAS, Jorge de Figueiredo (org.). Internacionalização do direito no novo século - Boletim da Faculdade de Direito da Universidade de Coimbra. Coimbra, Portugal: Coimbra Editora, 2009, pp. 127-144.
} 
maior ecletismo para se obter a solução do problema, tornando o pluralismo de métodos uma de suas características" ${ }^{271}$.

\subsubsection{A flexibilização das regras de conexão}

Por meio do princípio da proximidade, empreendeu-se a flexibilização das regras de conexão, antes tidas como inafastáveis (exceto pelos princípios tradicionais da autonomia da vontade, da ordem pública e da fraude à lei e, para alguns, pela aceitação do reenvio). Compreendida como ideia geral de que os fatos devem ser regidos pelo ordenamento que lhes seja mais próximo, o princípio representou um desenvolvimento do Direito Internacional Privado, passando-se a exigir uma ponderação dos diversos fatores de conexão do caso concreto em relação às leis potencialmente aplicáveis, em lugar da simples subsunção do caso à regra de conexão do foro ${ }^{272}$.

Em verdade, o princípio da proximidade já estaria presente, segundo a interpretação de Gutzwiller, no fragmento escrito por Aldricus, no séc. XII, em que este propôs a aplicação da lei melhor e mais útil ${ }^{273}$. Decerto, a ideia de proximidade seja necessária à própria existência do Direito Internacional Privado, enquanto disciplina que busca mediar as relações jurídicas que se expandem além do ordenamento jurídico local e podem, portanto, suscitar a aplicação de direito estrangeiro, nos casos em que este seja mais próximo à lide que o direito do foro.

Mais tarde, a teoria da sede do fato jurídico, de Savigny, levaria, por meio de seus elementos de conexão, à ideia de proximidade em nível abstrato (i.e., enquanto inspiração das regras de conexão). No entanto, é possível vislumbrar a proximidade já em nível concreto em certo trecho, no qual o jurista alemão afirma que a busca pelo domínio próprio

${ }^{271}$ ARAUJO, Nadia de. Direito Internacional Privado - teoria e prática brasileira. Rio de Janeiro: Renovar, $2006,3^{\text {a }}$ ed., p. 50.

272 Sobre o tema, vejam-se: LAGARDE, Paul. Le príncipe de proximité dans le droit international contemporain, Recueil des Cours, v. 196, t. I; DOLINGER, Jacob. Evolution of principles for resolving conflicts in the field of contracts and torts, Recueil des Cours, v. 283, Leiden/Boston: Martinus Nijhoff Publishers, 2000; e VALENTE DOS REIS, Gabriel. O Direito Internacional Privado e a teoria das qualificações: uma revisão do método conflitual a partir do princípio da proximidade, Revista de Direito do Estado - RDE (Renovar), n ${ }^{\circ}$ 3, 2009, pp. 293-325.

${ }^{273}$ GUTZWILLER, Max. Op. cit., p. 301; DOLINGER, Jacob. Evolution of principles for resolving conflicts in the field of contracts and torts, Recueil des Cours, v. 283, Leiden/Boston: Martinus Nijhoff Publishers, 2000, p. 394. 
ao qual pertence a relação jurídica deve obedecer a uma pesquisa independente, não se admitindo qualquer espécie de presunção geral ${ }^{274}$. Da mesma forma, a proximidade é a ideia básica da teoria do centro de gravidade da relação jurídica, defendida por Otto Gierke no fim do séc. XIX ${ }^{275}$.

No que concerne à jurisprudência, já em 1891 utilizou-se na Inglaterra o critério da “closest and most real connection" para determinar a lei aplicável ao contrato, no caso Chatenay v. Brazilian Submarine Telegraph ${ }^{276}$.

Não obstante essas origens remotas, o movimento de flexibilização acentuou-se durante o séc. $\mathrm{XX}^{277}$, com a fórmula francesa da "localização" do contrato, estabelecida pela Câmara Civil da Cour de Cassation francesa em julgamento de 5 de dezembro de $1910^{278} \mathrm{e}$, posteriormente, com a adoção do princípio da proximidade em diversas convenções internacionais ${ }^{279}$ e leis internas.

Destaca-se, nesse contexto, a Convenção de Roma sobre lei aplicável às obrigações contratuais, de 1980, vigente no âmbito da União Europeia, cujo art. $4^{\circ}, \mathrm{n}^{\circ} 1$, estabelece que, na ausência de eleição pelas partes, o contrato é regulado pela lei do país com o qual apresente uma conexão mais estreita. Do mesmo modo, a Convenção Interamericana sobre direito aplicável aos contratos internacionais, de $1994^{280}$, estatui no art. $9^{\circ}$ que " $n \tilde{a} o$ tendo as partes escolhido o direito aplicável, ou se a escolha do mesmo resultar ineficaz, o contrato reger-se-á pelo direito do Estado com o qual mantenha os vínculos mais estreitos".

${ }^{274}$ SAVIGNY, Friedrich Carl Von. Op. cit.. $\$ 361$, p. 123.

${ }^{275}$ DOLINGER, Jacob. Direito Internacional Privado - Parte Geral. Rio de Janeiro: Forense, 2011, $10^{\mathrm{a}}$ ed., p. 202; BASSO, Maristela. Op. cit., p. 128.

${ }^{276} 1$ QB 79, 1891.

${ }^{277}$ Para uma análise, no Brasil, dessa flexibilização, veja-se: MONACO, Gustavo Ferraz de Campos. $O p$. cit., pp. 82-93.

${ }^{278}$ Cf. LAGARDE, Paul. Op. cit., p. 30.

${ }^{279}$ Dentre as quais, podem ser citadas: Convenção de Genebra de 1930, sobre conflitos de nacionalidades (art. 5º); Convenção da Haia de 1961, sobre proteção de menores (art. 14); Convenção da Haia de 1961, sobre conflitos de leis relacionados à forma das disposições testamentárias (art. $\left.1^{\circ}, 2\right)$; Convenção da Haia de 1965, sobre jurisdição, lei aplicável e reconhecimento de decretos relacionados à adoção (art. 11); Convenção da Haia de 1978, referente à lei aplicável ao mandato (art. $6^{\circ}$ ); Convenção da Haia de 1989, sobre lei aplicável às sucessões e patrimônio de pessoas falecidas (art. 19); Convenção de Roma sobre lei aplicável às obrigações contratuais, de 1980 da Comunidade Europeia (art. $4^{\circ}, 1$ ); e Convenção Interamericana sobre direito aplicável a contratos internacionais, assinada em 1994, no México (art. $9^{\circ}$ ).

${ }^{280}$ Lamentavelmente, tal convenção ainda não foi ratificada pelo Brasil. 
O Regulamento "Roma I"281 da União Europeia, sobre lei aplicável às obrigações contratuais, também contempla o critério da lei mais proximamente conectada, enquanto exceção à aplicação das regras de conexão ali estabelecidas (art. $4^{\mathrm{o}}, 3$ ). Dispositivo semelhante pode ser encontrado no Regulamento "Roma II"282, no que concerne às obrigações extracontratuais (art. $\left.4^{\mathrm{o}}, 3\right)$.

Dentre as leis internas, aponte-se principalmente a exceção geral contida no art. 15, III, 1, da lei federal suíça sobre Direito Internacional Privado, de 18 de dezembro de 1987, que estatui que

\begin{abstract}
"o direito designado pela presente lei excepcionalmente não será aplicável se, do ponto de vista do conjunto das circunstâncias, é manifesto que a causa não possui senão um vínculo muito tênue com tal direito e que se encontra em uma relação muito mais estreita com outro direito".
\end{abstract}

Similarmente, os art. 28 e 41 da Lei de Introdução ao Código Civil Alemão (EGBGB) adotaram o critério da proximidade, respectivamente, na regulação das obrigações contratuais e extracontratuais ${ }^{283}$. Note-se que, atualmente, o art. 28 do EGBGB encontra-se revogado e substituído pelo Regulamento "Roma I" da União Europeia, que também adota a proximidade enquanto cláusula de exceção geral.

Também no Brasil a proximidade vem ganhando força nos últimos tempos. A despeito de nosso ultrapassado diploma legal sobre Direito Internacional Privado, de 1942, utilizar-se apenas de regras de conexão de estrutura rígida, o princípio vem encontrando abrigo em desenvolvimentos doutrinários e jurisprudenciais mais recentes. Em 1980, no prefácio à $5^{\mathrm{a}}$ edição do volume I de sua obra "Direito Internacional Privado", Haroldo Valladão afirmou:

\footnotetext{
${ }^{281}$ Regulamento (CE) n ${ }^{\circ}$ 593/2008 do Parlamento Europeu e do Conselho, de 17 de junho de 2008.

${ }^{282}$ Regulamento (CE) n ${ }^{\circ} 864 / 2007$ do Parlamento Europeu e do Conselho, de 11 de julho de 2007.

${ }^{283} \mathrm{O}$ art. 28, 1, estabelecia a proximidade como regra geral e o art. 28, 5, previa-a como exceção às presunções estabelecidas no texto legal. $\mathrm{O}$ art. 41, por sua vez, estabelece a proximidade enquanto exceção às regras de conexão que versam obrigações extracontratuais.
} 
"O direito estrangeiro deve ser considerado em seu sistema, integralmente, incluindo suas próprias regras de DIP, aceitando a devolução (o reenvio) e o princípio da renúncia ou da maior proximidade ${ }^{284}$.

Mais recentemente, Dolinger tem sido um grande defensor do princípio, chegando a afirmar que o Direito Internacional Privado, de um ponto de vista político, pode ser considerado o direito da proximidade, esta vista enquanto arte de aproximação entre os $\operatorname{povos}^{285}$.

Note-se que o princípio da proximidade foi adotado no Projeto de Lei $n^{\circ} 4.905$, de $1995^{286}$, em matéria de direito de família (art. $8^{\circ}, \S 5^{\circ}$ ), de obrigações contratuais (art. 11, $1^{\mathrm{o}}$ e $\S 3^{\circ}$ ) e de atos ilícitos (art. 12). Infelizmente, apesar de aprovado pela Comissão de Constituição e Justiça da Câmara dos Deputados, o PL 4.905/95 jamais foi enviado à votação em plenário. Em 2004, o Senador Pedro Simon propôs um novo projeto (O PL n ${ }^{\circ}$ 269 de 2004, do Senado), com algumas pequenas alterações em relação ao PL 4.905/95. O PL n 269, infelizmente, não teve melhor sorte, tendo sido arquivado em 07.01.2011, por ocasião do término da legislatura.

No Recurso de Revista $\mathrm{n}^{\circ}$ 186000-18.2004.5.01.0034 ${ }^{287}$ julgado em 06.10.2010, pela $1^{\text {a }}$ Turma do Tribunal Superior do Trabalho (TST), o princípio da proximidade foi utilizado para justificar a aplicação da legislação brasileira, no caso de um trabalhador contratado no Brasil e posteriormente transferido sucessivamente a diversos países estrangeiros (Inglaterra, Holanda e Chile). O argumento foi de que, dada a complexidade da relação contratual e a existência de elementos que indicavam que o trabalhador retornaria ao Brasil (destacando-se a manutenção de depósitos em sua conta vinculada do

${ }^{284}$ VALLADÃO, Haroldo. $O p$. cit., prefácio à $5^{\text {a }}$ edição.

${ }^{285}$ DOLINGER, Jacob. Contratos e obrigações no Direito Internacional Privado. Rio de Janeiro: Renovar, 2007, pp. 543-551. Vejam-se, também: DOLINGER, Jacob. Evolution of principles for resolving conflicts in the field of contracts and torts, Recueil des Cours, v. 283, Leiden/Boston: Martinus Nijhoff Publishers, 2000; DOLINGER, Jacob. Direito Internacional Privado - Do princípio da proximidade ao futuro da humanidade. In: Direito e Amor. Rio de Janeiro: Renovar, 2009, pp. 145-153; e VALENTE DOS REIS, Gabriel. O Direito Internacional Privado e a teoria das qualificações: uma revisão do método conflitual a partir do princípio da proximidade, Revista de Direito do Estado - RDE (Renovar), n 13, 2009, pp. 293325.

${ }^{286} \mathrm{O}$ PL n ${ }^{\circ} 4.905 / 95$ foi um projeto de lei sobre aplicação das normas jurídicas, destinado a substituir a Lei de Introdução de 1942, tendo resultado de anteprojeto elaborado por uma comissão formada por quatro destacados juristas: Jacob Dolinger (UERJ), João Grandino Rodas (USP), Inocêncio Mártires Coelho (UNB) e Rubens Limongi França (USP).

${ }^{287}$ Publicado no DEJT de 15.10.2010. Vejam-se também os Embargos de Declaração, tendo sido mantido o teor do julgamento (E-ED-RR n ${ }^{\circ}$ 186000-18.2004.5.01.0034, julgados em 05.05.2011, publicados no DEJT de 13.05.2011). 
FGTS, durante todo o período contratual), o critério da lex loci executionis deveria ser afastado em benefício da aplicação da lei brasileira.

Este julgado nos leva à reflexão de que o princípio da proximidade pode ser utilizado para justificar a aplicação da lei do foro; e que, em determinados casos, isso pode esconder uma atitude unilateralista e provinciana.

Nos EUA, a proximidade e o método unilateral às vezes aparecem em conjunto, como comprovam os casos Auten v. Auten ${ }^{288}$ e Babcock v. Jackson ${ }^{289}$, julgados pela Corte de Apelação de Nova York, que utilizaram em conjunto a teoria do "centro de gravidade" e a ideia da jurisdição com "interesse mais forte", i.e., a teoria dos interesses governamentais de Currie ${ }^{290}$.

Isto posto, cumpre fazer a seguinte ressalva fundamental: a flexibilidade proporcionada pelo princípio deve ser acompanhada de uma conscientização de seus aplicadores, no sentido de não o desvirtuarem, devendo ser respeitadas as bases filosóficas daquele.

De qualquer modo, no Recurso de Revista $\mathrm{n}^{\circ} 186000-18.2004 .5 .01 .0034$, a $1^{\mathrm{a}}$ Turma do TST procedeu a uma ponderação de diversos fatores antes de optar pela lei brasileira, e parece só tê-lo feito em decorrência de dois motivos somados: (i) a maior proximidade do ordenamento brasileiro em relação ao contrato de trabalho; e (ii) a complexidade da relação jurídica em questão, visto que o reclamante trabalhou sucessivamente em diversos países.

Frise-se que esse movimento de flexibilização, derivado da ideia de proximidade em nível concreto, que ganhou força sobretudo ao longo do séc. XX, não foi exatamente um recuo em relação à ótica multilateralista; mas em verdade constituiu a elevação desta a uma potência maior. $\mathrm{Na}$ medida em que as regras de conexão multilaterais sempre encontraram sua justificativa básica na ideia de proximidade, como demonstrado, pode-se dizer que o que houve foi um reforço do princípio subjacente às mesmas. A flexibilização, assim, busca atender ainda mais à premissa básica da ótica multilateralista: a busca da lei

\footnotetext{
288308 N. Y. 155, 1954.

28912 NY2d 473, 1963

290 Saliente-se que, apesar de utilizarem a ótica unilateral, os resultados atingidos nesses dois casos específicos não parecem refletir provincianismo. Sobre a teoria dos interesses governamentais, veja-se o item III.2.2, supra.
} 
mais intimamente ligada à relação jurídica e às partes, tomando-se o caso concreto como ponto de partida para tal busca.

Como propõem Brilmayer e Anglin, a determinação da lei aplicável deve ser, em regra, uma função do contexto fático como um todo, e não teorizada a partir da escolha de um elemento de conexão único, a ser considerado sempre mais importante que todos os outros contatos presentes ${ }^{291}$. Encontrando-se os contatos dispersos (como eles frequentemente estão atualmente) - ou, pior ainda, quando todos os contatos apontam em uma direção e o elemento de conexão rígido indica outra, basear a decisão nesse contato solitário parece arbitrário e fortuito ${ }^{292}$. Dessa forma, as autoras defendem um método mais flexível, de ponderação dos diversos contatos concorrentes ${ }^{293}$.

Note-se que o princípio da proximidade permite, ou antes determina, que se proceda exatamente a essa ponderação. É por meio da técnica ponderativa que o intérprete considerará todos os elementos objetivos e subjetivos presentes no caso, em relação aos sistemas jurídicos potencialmente aplicáveis, encontrando subsídios que o auxiliem na determinação da conexão mais íntima ${ }^{294}$.

Nesse sentido, enxergamos na proximidade um grande potencial de impulsionar a cosmopolitização do direito, constituindo importante instrumento de avanço do cosmopolitismo empírico-analítico no âmbito da teoria jurídica. Ao analisar os vários fatores de conexão do caso concreto com os ordenamentos jurídicos potencialmente aplicáveis, o intérprete analisa os graus de vinculação da disputa com diferentes ordens sociais e jurídicas, tratando-a de acordo com sua complexidade cosmopolita.

Parece haver, em verdade, um fenômeno de reafirmação mútua entre a proximidade e a cosmopolitização da realidade, na medida em que a própria transnacionalização da vida confere força ao princípio, uma vez que se torna mais problemático estabelecer uma regra de conexão rígida que contemple um único elemento de conexão (i.e., uma regra reducionista), pois frequentemente os casos terão contato com múltiplas ordens jurídicas, em aspectos variados e não desprezíveis.

291 BRILMAYER, Lea; ANGLIN, Rachel. Choice of law theory and the metaphysics of the stand-alone trigger. Iowa Law Review, no 95, 2010, p. 1128.

${ }^{292}$ Idem, p. 1149.

${ }^{293}$ Ibidem, p. 1167-1175.

${ }^{294}$ Sobre a relação entre o princípio da proximidade e a técnica da ponderação, veja-se: VALENTE DOS REIS, Gabriel. O Direito Internacional Privado e a teoria das qualificações: uma revisão do método conflitual a partir do princípio da proximidade, Revista de Direito do Estado - RDE, n 13, pp. 302-305. 
Assim, o princípio evita dois reducionismos: (i) o de um nacionalismo metodológico provinciano que aplica a lei do foro automaticamente, sem se perguntar qual lei se relaciona mais intensamente à disputa e às partes; e (ii) o das regras de conexão rígidas, que elegem um único elemento de conexão, formal, inescapável, enquanto critério de determinação da lei aplicável em dada matéria.

\subsubsection{A publicização do direito e as lois de police}

No curso do séc. XX, com o crescimento da intervenção estatal, fosse esta de caráter dirigista (ex.: normas trabalhistas, de seguridade social e de direito do consumidor) ou liberal (ex.: direito da concorrência e regulação dos mercados de capitais), a distinção entre direito público e privado perdeu força ${ }^{295}$. Houve certa publicização do direito, que passou a dar uma ênfase maior a objetivos perseguidos pelo Estado.

Enquanto nos Estados Unidos esse movimento histórico foi um dos fatores que levaram ao abandono do multilateralismo em favor do unilateralismo, nos sistemas civilistas ele propiciou a identificação de uma nova categoria de normas, ditas "de aplicação necessária" ou "imediata" (lois de police), cuja aplicação não pode ser afastada pelas regras de conexão multilaterais ${ }^{296}$. O grande propulsor da teoria das lois de police foi Francescakis, em meados do séc. XX, que as definiu como regras “cujo cumprimento é necessário para a salvaguarda da organização política, social e econômica do país"297.

Em verdade, trata-se muito mais de uma redescoberta, i.e., de um retorno às origens do multilateralismo, do que propriamente de uma grande novidade. Isso porque é nítida a identidade entre a noção de lois de police e as "leis de natureza rigorosamente positiva, coativa”, ditadas por motivos de interesses gerais, de caráter político, de ordem

\footnotetext{
${ }^{295}$ Cf. AUDIT, Bernard. Op. cit., p. 267. Note-se que, ao contrário de Audit, consideramos que o direito do consumidor parece possuir traços mais dirigistas do que liberais. A distinção, contudo, não deve ser exagerada.

${ }^{296}$ Idem, pp. 267-268.

${ }^{297}$ FRANCESCAKIS, Phocion. Rep. Dalloz de droit international, 1a ed., verbete "Conflit de lois", n 137, apud GAUDEMET-TALLON, Hélène. Op. cit., p. 257, nota n 694. Vejam-se, também: BONOMI, Andrea. Le norme imperative nel diritto internazionale privato. Zurique: Schulthess, 1998; e HARTLEY, Trevor C. Mandatory rules: the Common Law approach, Recueil des Cours, v. 266, Leiden/Boston: Martinus Nijhoff Publishers, 1997.
} 
pública ou de economia política às quais Savigny referiu-se enquanto exceções ao método multilateral ${ }^{298}$.

Registre-se, aqui, que a noção de lois de police não deve ser confundida com as normas imperativas do direito doméstico. A categoria, no âmbito do Direito Internacional Privado, é mais restrita - nem toda norma imperativa no sentido do direito interno será uma loi de police no sentido do Direito Internacional Privado.

Observe-se que diversas convenções internacionais adotaram a técnica das lois de police. Mencionem-se, especialmente, as seguintes: Convenção Interamericana sobre direito aplicável aos contratos internacionais, de 1994 (art. 11); Convenção de Roma sobre lei aplicável às obrigações contratuais, de 1980, da União Europeia (art. $7^{\circ}$ ); Convenção da Haia sobre lei aplicável aos contratos de venda internacional de mercadorias, de 1986 (art. 17); Convenção da Haia sobre lei aplicável ao mandato, de 1978 (art.16); Convenção da Haia sobre lei aplicável aos trusts e seu reconhecimento, de 1985 (art. 16); Convenção da Haia sobre lei aplicável à sucessão e ao patrimônio de pessoas falecidas, de 1989 (art. 15); Convenção da Haia sobre proteção internacional de adultos, de 2000 (art. 20); e Convenção da Haia sobre lei aplicável a certos direitos relacionados a valores mobiliários detidos por um intermediário, de $2006\left(\operatorname{art} .11, \mathrm{n}^{\circ} 2\right)$.

É possível enxergar nas lois de police uma força expansionista do direito ao qual pertencem, o que pode ser um obstáculo a uma boa coordenação de sistemas ${ }^{299}$. Desse modo, a noção de normas de aplicação necessária ou imediata aproxima-se do método unilateralista, porquanto se concentra no âmbito de aplicação da lei do foro, traduzindo-se na decisão, por parte do legislador ou do juiz, acerca da caracterização ou não da loi de police em determinada matéria.

Assim é que a utilização das lois de police guarda alguma semelhança com o método estadunidense dos interesses governamentais. A diferença é que, para a teoria norte-americana correspondente, o método atua para todos os fins e em qualquer matéria, ao passo que na teoria civilista ele se restringe a determinadas lois de police ${ }^{300}$. Em outras palavras, as lois de police são sempre excepcionais, ao passo que a teoria dos interesses

\footnotetext{
${ }^{298}$ SAVIGNY, Friedrich Carl Von. Op. cit.. §349, pp. 54-56.

${ }^{299}$ GAUDEMET-TALLON, Hélène. Op. cit., pp. 260-261.

${ }^{300}$ AUDIT, Bernard. Op. cit., p. 286.
} 
governamentais representa uma abordagem básica que busca orientar todas as áreas do Direito Internacional Privado ${ }^{301}$.

Note-se que a possibilidade de aplicação de lois de police de outros Estados, ou ao menos de tomá-las em consideração, diminui o potencial prejuízo à coordenação de sistemas que elas representam ${ }^{302}$. Some-se a isto o caráter excepcional de tais normas, que deve ser sublinhado. No Direito Internacional Privado, não é conveniente que a categoria das lois de police se estenda além do estritamente necessário ${ }^{303}$. Com efeito, o abuso das normas de aplicação necessária, seja por parte do legislador, seja por parte do juiz, revela tendência provinciana, contrária às exigências da justiça cosmopolita.

Desse modo, cumpre ao juiz, igualmente, levar em conta as lois de police estrangeiras, também de forma a não incorrer em provincianismo. Como leciona Audit:

\footnotetext{
"a tomada em consideração das lois de police estrangeiras tornou-se vislumbrável. Atualmente, é amplamente admitido, ainda que com múltiplas nuances, que um Estado possa, e talvez mesmo que deva, emprestar a mão à realização de objetivos perseguidos por um Estado estrangeiro, desde que lhe pareçam legítimos" ${ }^{\text {304 }}$.
}

A devida consideração das lois de police estrangeiras, somada à moderação por parte do legislador e a uma interpretação restritiva por parte do juiz ao delimitarem a abrangência das lois de police do foro, permite que tais normas atendam à sua real finalidade $-\mathrm{a}$ de protegerem, excepcionalmente, certos interesses públicos essenciais para os diversos ordenamentos estatais, sem anular, no entanto, a estrutura básica do multilateralismo.

\footnotetext{
${ }^{301}$ DOLINGER, Jacob. Contratos e obrigações no Direito Internacional Privado. Rio de Janeiro: Renovar, 2007, p. 149.

${ }^{302}$ GAUDEMET-TALLON, Hélène. Op. cit., p. 261. A autora faz alusão ao caso Alnati, julgado pela Corte de Cassação dos Países Baixos em 13.05.1966, no qual se aplicou uma loi de police estrangeira, bem como ao art. $7^{\circ}, \S 1^{\circ}$, da Convenção de Roma, que também prevê a possibilidade dessa aplicação. $\mathrm{O}$ art. $9^{\circ}$, $\S 3^{\circ}$, do Regulamento "Roma I", possui previsão semelhante. Em relação às codificações internas, aponte-se o art. 19 da Lei suíça sobre Direito Internacional Privado, bem como para o art. 3079 do Código Civil do Quebec. ${ }^{303}$ Idem, p. 264.

${ }^{304}$ AUDIT, Bernard. Op. cit., p. 283. Tradução livre.
} 


\subsubsection{Materialismo e regras de conexão substanciais}

O recrudescimento do materialismo foi outro fenômeno observado nas últimas décadas. Registre-se que o multilateralismo jamais foi completamente alheio à importância de certos valores substanciais, sobretudo se levando em conta que, desde os primórdios da disciplina, o princípio da ordem pública atua, em caráter excepcional, para afastar soluções concretas manifestamente incompatíveis com uma concepção de justiça material mínima do foro. Similarmente, o princípio da vedação da fraude à lei, que afasta a aplicação da lei estrangeira em casos nos quais as partes modificaram um elemento de conexão com o único intuito de escapar da aplicação de determinada lei, revela uma preocupação de justiça material, relacionada ao princípio geral da boa-fé.

Como afirma Hélène Gaudemet-Tallon, tanto a exceção da ordem pública como a exceção da fraude à lei são meios de se lutar contra o caráter mecânico das regras de conexão, e de se assegurar que objetivos de justiça material sejam tomados em consideração $^{305}$. O princípio da autonomia da vontade, por sua vez, também leva em conta a justiça material, na medida em que permite às partes escolherem a lei que mais atenda a seus interesses específicos ${ }^{306}$ - desde que não se encontrem em posição de desigualdade significativa quando da negociação.

Mas, principalmente a partir da metade do séc. XX, até os dias atuais, o materialismo passou a se manifestar também de outra forma nos países de tradição romano-germânica: por meio de uma maior utilização de regras de conexão ditas substanciais. Tais regras, apesar de não abandonarem completamente a preocupação localizadora do método conflitual, incorporam uma orientação material, no sentido de privilegiarem a escolha de um direito que conduza a determinado resultado concreto. Desse modo, por meio de elementos de conexão alternativos, sucessivos ou cumulativos, bem como da noção de lei mais favorável, prioriza-se a aplicação de determinada lei em virtude de seu conteúdo material.

Um bom exemplo pode ser extraído da Convenção da Haia sobre conflitos de leis relacionados à forma das disposições testamentárias, de 1961 , cujo art. $1^{\circ}$ privilegia o valor

\footnotetext{
${ }^{305}$ GAUDEMET-TALLON, Hélène. Op. cit., p. 281.

${ }^{306}$ Idem, p. 283.
} 
material da preservação da validade do testamento, por meio de conexões alternativas ${ }^{307}$. Nesse sentido, o dispositivo estatui que uma disposição testamentária será formalmente válida se atender a qualquer um dos seguintes direitos internos: (a) do local onde foi feito o testamento; (b) de uma nacionalidade possuída pelo testador, seja no momento da disposição, seja no momento de sua morte; (c) do local onde o testador era domiciliado, seja no momento da disposição, seja no momento de sua morte; (d) do local onde o testador possuía residência habitual, seja no momento da disposição, seja no momento de sua morte; ou (e) em relação a imóveis, do local onde estão situados.

Note-se que tal regra privilegia sistematicamente o sucessor testamentário a quem a disposição aproveita, em detrimento dos demais herdeiros ab intestato. Pode-se discutir se tal tratamento diferenciado seria justo, sobretudo porque isso não ocorreria na hipótese de o testamento circunscrever-se ao âmbito do direito interno ${ }^{308}$.

Além do favor negotii, outros princípios podem inspirar regras de conexão substanciais. Tome-se o exemplo da Convenção da Haia sobre lei aplicável às obrigações alimentares, de 1973 , cujos arts. $4^{\circ}, 5^{\circ}$ e $6^{\circ}$ estabelecem uma série de conexões sucessivas que visam a garantir que o credor obtenha alimentos. A ideia de tal mecanismo é garantir a proteção de uma parte presumidamente hipossuficiente.

$\mathrm{O}$ art. $4^{\mathrm{o}}$ da Convenção estabelece, como regra geral, a aplicação da lei da residência habitual do credor de alimentos. $\mathrm{O}$ art. $5^{\circ}$, por sua vez, esclarece que, se tal lei não possibilitar a obtenção dos alimentos, a lei da nacionalidade comum de credor e devedor deverá ser aplicada. Por fim, o art. $6^{\circ}$ determina que, no caso das duas leis anteriores não permitirem a cobrança de alimentos, o direito do foro será aplicado. Assim é que a convenção almeja garantir, por meio de conexões sucessivas (ou subsidiárias), que o credor de alimentos não fique desamparado.

\footnotetext{
${ }^{307}$ Note-se que o princípio do favor negotii não é novo e já fora delineado por Savigny em sua obra: “ $A$ verdadeira posição de nossa regra [locus regit actum] levanta uma dúvida muito importante: a observação da forma estabelecida no local em que intervém o ato jurídico é absolutamente necessária ou simplesmente facultativa, de modo que as partes podem escolher entre essa forma e aquela do local a que pertence na realidade o ato jurídico? Se for considerado que essa regra especial é feita para favorecer as partes e para facilitar as transações civis, não se poderia duvidar de que seja simplesmente facultativa e de que se possa escolher uma ou outra forma. Por isso, essa doutrina é geralmente admitida" (SAVIGNY, Friedrich Carl Von. Op. cit., §381, p. 283). No mesmo sentido, Savigny cita Rodenburg, Foelix e Wächter, dentre outros autores.

${ }^{308}$ GAUDEMET-TALLON, Hélène. Op. cit., p. 237.
} 
É possível, também, a utilização de conexões cumulativas, que manifestam a vontade de evitar determinado resultado (ex.: em tese, pode-se estabelecer que um segundo casamento, simultâneo, por parte do marido, só será reputado válido se tanto a sua lei pessoal quanto a lei pessoal de sua primeira esposa assim o permitam, i.e., se ambas consagrarem regimes poligâmicos) ${ }^{309}$.

A utilização de regras de conexão substanciais está geralmente relacionada a uma filosofia que busca a proteção de determinadas pessoas ou a preservação de certas instituições (favor infans, favor negotii, favor matrimonii, favor divortii etc) ${ }^{310}$.

Observe-se que tais regras, assim como o método materialista em geral, trazem consigo o risco de manifestarem uma preferência velada pelo direito do foro e por seus valores $^{311}$. Além disso, como afirmou Lagarde, parece mais difícil obter a uniformização do Direito Internacional Privado, em nível internacional, por meio de regras de conexão substanciais do que por meio de regras de conexão neutras, do que se conclui que a utilização de tais regras deve constituir um último recurso ${ }^{312}$. Parece-nos, por conseguinte, que as regras de conexão substanciais devem ser utilizadas com parcimônia e, sobretudo, em atenção a princípios já consolidados ao longo dos séculos na esfera internacional, como é o caso do favor negotii.

\subsubsection{Considerações críticas}

Apesar de multilateralismo, unilateralismo e materialismo não serem necessariamente excludentes, isto não significa que não é preciso compará-los criticamente, tampouco que não se deva optar por um dos métodos enquanto estrutura principal para a determinação da lei aplicável. Conforme demonstrado, multilateralismo, unilateralismo e materialismo são abordagens que se baseiam em premissas distintas e

\footnotetext{
${ }^{309}$ AUDIT, Bernard. Op. cit., p. 338. O exemplo dado pelo autor francês não exclui as questões de ordem pública que podem ser suscitadas nessa seara e, a depender das circunstâncias do caso concreto, levar à ineficácia do segundo casamento, por outros caminhos.

${ }^{310}$ DOLINGER, Jacob. Contratos e obrigações no Direito Internacional Privado. Rio de Janeiro: Renovar, 2007, pp. 98-99.

${ }^{311}$ GAUDEMET-TALLON, Hélène. Op. cit., p. 237-238.

${ }^{312}$ LAGARDE, Paul. Op. cit., p. 60. A expressão francesa utilizada é "pis-aller".
} 
levam a resultados diferentes. Nesse sentido, a hesitação metodológica pode apresentar sérios inconvenientes ${ }^{313}$.

Em relação à crítica feita pela teoria estadunidense a respeito do caráter supostamente mecanicista e extremamente abstrato do multilateralismo, é preciso afirmar, como o fez Pierre Lalive, que a consideração de valores e objetivos, na determinação da lei aplicável, não é fenômeno novo, e a doutrina multilateralista abandonou, há tempos, os excessos conceptualistas ${ }^{314}$.

Assim, princípios tradicionais como a ordem pública e a vedação da fraude à lei, bem como princípios mais recentes como a proteção da parte mais frágil, são instrumentos para salvaguardar alguns valores materiais. Ademais, a ascensão do princípio da proximidade importou uma flexibilização na aplicação das regras de conexão. Desse modo, como nota Gustavo Monaco:

\begin{abstract}
“seja pela construção da norma jurídica com a indicação de critérios alternativos ou subsidiários de conexão, seja autorizando-se o recurso às cláusulas de exceção, fato é que o sistema de Direito Internacional Privado procurou abrir a possibilidade de que o julgador se afastasse do método clássico, sempre com o intuito de proceder à justiça conflitual, permitindo a aplicação de uma lei que, em princípio não seria aplicada, muito embora fosse, na hipótese, aquela que maior conexão apresentasse para a resolução da situação fática” ${ }^{315}$.
\end{abstract}

No que concerne ao materialismo (ou substantivismo) unilateralista, esperamos haver demonstrado que a busca pela justiça material a todo custo geralmente esconde, no Direito Internacional Privado, uma tendência provinciana a querer impor os próprios valores a todos os demais. Para se atender às exigências da justiça cosmopolita, é preciso estar aberto a valores diferentes dos próprios, e isso se obtém mediante a aplicação da lei estrangeira, sempre que esta for mais próxima aos fatos e/ou às partes, respeitando os valores culturais e particularidades dos diversos sistemas jurídicos.

\footnotetext{
${ }^{313}$ Em sentido semelhante, veja-se JUENGER, Friedrich. Op. cit., p. 143.

${ }^{314}$ LALIVE, Pierre. Tendances et méthodes en Droit International Privé. Recueil des Cours, v. 155, Leiden/Boston: Martinus Nijhoff Publishers, 1977, p. 369.

${ }^{315}$ MONACO, Gustavo Ferraz de Campos. Op. cit., p. 85.
} 
Desse modo, deve-se evitar uma oposição absoluta entre os sistemas multilateralista, unilateralista ${ }^{316}$ e materialista, pois a realidade é permeada de nuances, mas não se deve fugir à escolha de uma matriz teórica principal.

O método multilateralista, nesse sentido, parece o mais apto, ao menos no atual estágio de desenvolvimento do cenário internacional, a garantir um mínimo de imparcialidade cosmopolita. As regras de conexão, temperadas pelos princípios tradicionais da disciplina e flexibilizadas pelo princípio da proximidade, constituem um contrapeso à tendência instintiva do juiz de aplicar seu próprio direito e/ou valores, desconsiderando a vinculação múltipla do caso com ordenamentos vários. Atuam, assim, em favor da imparcialidade cosmopolita, pois consideram, como ponto de partida, todos os direitos potencialmente aplicáveis de modo igual, sem privilegiar a ordem jurídica do foro.

Como visto, a flexibilização das regras de conexão tradicionais (princípio da proximidade), a redescoberta das normas de aplicação necessária ou lois de police, bem como uma maior utilização de regras de conexão substanciais, acabaram incorporando ao método multilateralista algumas preocupações do unilateralismo (ex.: interesses públicos) e do materialismo (ex.: proteção da parte hipossuficiente).

Não obstante, tanto as lois de police quanto as regras de conexão substanciais devem ser vistas como excepcionais. O norte geral do multilateralismo permanece a busca da lei mais próxima, com o auxílio de presunções estabelecidas em regras de conexão neutras, baseadas na ideia de igualdade entre os sistemas jurídicos estatais. Esse é o método mais apropriado que se concebeu até o momento, e também o mais apto a mediar a complexidade das relações jurídicas no mundo contemporâneo ${ }^{317}$.

Essa complexidade cosmopolita, traduzida na existência de vínculos plurais, simultâneos, multidimensionais e dinâmicos dos indivíduos e fatos sociais com diversas ordens jurídicas (cf. o item I.2.5.1, supra), impõe a análise dos diversos fatores de conexão do caso concreto, de forma a verificar suas intensidades e decidir entre eles. Não se deve negar o problema básico do Direito Internacional Privado (a existência de ordens jurídicas divergentes e igualmente legítimas) por meio de uma aplicação automática, provinciana, do direito do foro. Tampouco se deve privilegiar uma concepção etérea de justiça material do juiz, em tese independente dos direitos existentes, mas na prática frequentemente ligada

\footnotetext{
${ }^{316}$ Veja-se AUDIT, Bernard. Op. cit., p. 288.

${ }^{317}$ Em sentido semelhante, GAUDEMET-TALLON, Hélène. Op. cit., pp. 297-298.
} 
aos valores e direito particulares daquele. Dessa forma, parece-nos que o multilateralismo é o método que mais respeita o cosmopolitismo empírico-analítico, evitando reducionismos nacionalistas.

Isso não significa, logicamente, que não haja um longo caminho a percorrer. Os desafios e imperfeições do sistema são muitos, mas as respostas não residem em "revoluções" ou atalhos milagrosos. Nesse sentido, mais cabe desenvolver, a partir do marco teórico existente, parâmetros jurídicos que tornem o direito mais justo conforme critérios cosmopolitas, bem como impulsionar a prática desses parâmetros por parte dos intérpretes (e, diga-se, daqueles já existentes, porém pouco praticados), trazendo-os à realidade viva. 


\section{CAPÍTULO IV}

\section{VISÃO COSMOPOLITA DA ORDEM PÚBLICA}

SUMÁRIO: 1. Aspectos gerais. 2. Intensidade da aplicação da ordem pública em função da proximidade com o foro. 3. Ordem pública verdadeiramente internacional. 4. Ordem pública e determinação da lei aplicável: jurisprudência brasileira. 4.1. Regime de bens. 4.2. Casamento no exterior de pessoa desquitada no Brasil. 4.3. Dívida de jogo contraída no exterior. 4.4. Prazo prescricional estabelecido em lei estrangeira. 4.5. Autonomia da vontade e ordem pública verdadeiramente internacional.

\section{ASPECTOS GERAIS}

Se a aplicação do direito estrangeiro pelo juiz nacional, conforme determinam as normas de Direito Internacional Privado, repousa sobre o princípio da proximidade, que preconiza a busca da lei mais próxima à relação jurídica e às partes; o princípio da ordem pública, ao menos em sua acepção tradicional, representa uma exceção a esse sistema, resultando na rejeição da solução dada pelo direito estrangeiro sempre que esta for manifestamente incompatível com os valores essenciais do foro. Dessa forma, cumpre buscar um equilíbrio entre a estrutura geral de tolerância e a proteção da ordem pública do sistema jurídico local. Ou, na precisa lição de Maristela Basso, "devemos buscar o 'equilíbrio' entre a obrigação de aplicar o direito estrangeiro (como se juiz estrangeiro fosse) e o respeito à ordem pública local ${ }^{318}$.

No que concerne ao direito brasileiro, a ordem pública de Direito Internacional Privado encontra-se consagrada no art. 17 da Lei de Introdução, que estipula que "as leis, atos e sentenças de outro país, bem como quaisquer declarações de vontade, não terão eficácia no Brasil, quando ofenderem a soberania nacional, a ordem pública e os bons costumes". A exceção da ordem pública também está prevista no art. $5^{\circ}$ da Convenção Interamericana sobre Normas Gerais de Direito Internacional Privado, de 1979, vigente

${ }^{318}$ BASSO, Maristela. Op. cit., p. 262. 
entre nós 319 , o qual dispõe que "a lei declarada aplicável por uma convenção de Direito Internacional Privado poderá não ser aplicada no território do Estado Parte que a considerar manifestamente contrária aos princípios da sua ordem pública”.

Devendo-se aferir o que vem a constituir a ordem pública a partir da mentalidade e sensibilidade médias de determinada sociedade em dada época, aquela possui como características centrais a relatividade, a instabilidade e a contemporaneidade ${ }^{320}$. Em primeiro lugar, a ordem pública varia conforme a região (relatividade). Em segundo lugar, altera-se com o passar do tempo (instabilidade). Por fim, o juiz deve auscultar a noção de ordem pública prevalecente quando do julgamento, pouco importando aquela do momento em que ocorreram os fatos pretéritos (contemporaneidade). Desse modo, como observa Valladão, trata-se de "uma noção fluida, relativíssima, que se amolda a cada sistema jurídico, em cada época, e fica entregue à jurisprudência em cada caso"321.

A doutrina sublinha a atuação da ordem pública em três esferas distintas, com intensidade decrescente: (i) no plano interno; (ii) na aplicação direta da lei estrangeira; e (iii) em face de situações regularmente constituídas no exterior ${ }^{322}$. No primeiro nível plano do direito interno, a ordem pública proíbe que o teor de determinadas normas, tida como imperativas pelo sistema jurídico, seja afastado pela vontade privada. No segundo nível, a ordem pública impede que se aplique determinado direito estrangeiro, designado como competente pela regra de conexão do foro, quando tal aplicação for chocante aos valores fundamentais deste. Note-se que nem tudo que for considerado matéria de ordem pública no âmbito interno impedirá a aplicação do direito estrangeiro, na medida em que a ordem pública, no segundo nível, é menos exigente que no primeiro. Já no terceiro nível, a ordem pública só atua em face de violações gravíssimas, tendo aplicação ainda mais restrita. Assim, o intérprete só deverá desconsiderar situações regularmente consolidadas no exterior em casos verdadeiramente excepcionais - observa-se, aqui, um efeito atenuado da ordem pública.

\footnotetext{
${ }^{319}$ Promulgada pelo Decreto n ${ }^{\mathrm{o}} 1.979$, de 09.08.1996.

${ }^{320}$ Veja-se: DOLINGER, Jacob. Direito Internacional Privado - Parte Geral. Rio de Janeiro: Forense, 2011, $10^{\text {a }}$ ed., pp. 389-394.

${ }^{321}$ VALLAD $\tilde{O}$, Haroldo. Op. cit., p. 496.

322 DOLINGER. Jacob. A evolução da ordem pública no Direito Internacional Privado. Tese apresentada para o concurso à cátedra de Direito Internacional Privado da Faculdade de Direito da UERJ. Rio de janeiro, 1979, pp. 41-42; DOLINGER, Jacob. Direito Internacional Privado - Parte Geral. Rio de Janeiro: Forense, 2011, $10^{\text {a }}$ ed., pp. 394-400; e TIBURCIO, Carmen. Temas de Direito Internacional. Rio de Janeiro: Renovar, 2006, pp. 522-523.
} 
Elegemos acima, como um dos parâmetros cosmopolitas de reflexão, a necessidade de se buscar um equilíbrio entre o particular e o universal, entre o respeito à diferença e um mínimo universal inegociável (cf. I.2.5.4, supra). Apontamos para a necessidade de se evitar tanto um universalismo soberbo, arrogante; quanto um relativismo absoluto, impotente e acrítico. Nesse contexto, acreditamos que o princípio da ordem pública pode ser utilizado justamente para buscar tal equilíbrio no âmbito do Direito Internacional Privado.

Retome-se a lição de Appiah: se é certo que a tolerância é um pré-requisito cosmopolita, por outro lado é preciso cessar o diálogo quando os fatos violam nossos princípios fundamentais de maneira profunda $^{323}$. Como já referido ${ }^{324}$, respeitar visões diferentes não equivale a aceitar cegamente qualquer valor que venha de fora - um valor externo que reflita intolerância, por exemplo, não deve ser tolerado, sob pena de enfraquecimento do próprio sistema aberto e imparcial. Eis exatamente o papel do princípio da ordem pública: afastar a aplicação do direito estrangeiro quando este se chocar gravemente contra valores fundamentais do foro.

Mas o princípio também pode ser utilizado para justificar uma indesejável postura provinciana de simples fuga do direito estrangeiro. Nesse sentido, Maristela Basso constata “certa tendência natural do juiz nacional de repelir a aplicação da lei estrangeira, substituindo-a pela lex fori, alegando ou invocando o princípio geral e abstrato da ordem pública"325. A autora prossegue afirmando que isso acontece "porque ainda há certos focos de sentimento chauvinista e de desejo de simplificar e facilitar o julgamento aplicando a lei local - conhecida" ${ }^{326}$. Similar é o alerta de Dolinger, para quem

\footnotetext{
“a ordem pública que funciona no Direito Internacional Privado como válvula de segurança poderá ser abusivamente utilizada por aqueles que resistem à aplicação da lei estrangeira por não assimilarem adequadamente a noção de comunidade jurídica internacional”,327.
}

\footnotetext{
${ }^{323}$ APPIAH, Kwame A. Op. cit., p. 21.

${ }^{324}$ Veja-se o item I.2.2, supra.

${ }^{325}$ BASSO, Maristela. Op. cit., p. 262.

${ }^{326}$ Idem.

327 Veja-se: DOLINGER, Jacob. Direito Internacional Privado - Parte Geral. Rio de Janeiro: Forense, 2011, 10 ed., p. 428.
} 
Para evitar que o princípio sirva ao provincianismo, deve ser sublinhado que a ordem pública é excepcional, i.e., para ter sua aplicação afastada, o direito estrangeiro deve implicar uma contradição manifesta com os princípios jurídicos fundamentais do foro, não sendo suficiente uma mera diferença de $\operatorname{conteúdos}^{328}$. A consequência prática da natureza excepcional do princípio é que este deve ser interpretado restritivamente, como já defendia Pillet $^{329}$. Assim, o aplicador do direito deve recorrer à exceção da ordem pública com parcimônia, somente quando absolutamente necessário ${ }^{330}$.

Tal excepcionalidade pode ser relacionada à ideia cosmopolita de busca por imparcialidade. Inspirando-se na imagem do espectador imparcial de Adam Smith (veja-se o item I.2.4, supra), é possível elaborar o seguinte raciocínio: se nosso instinto natural é ser parcial e se apenas o esforço racional pode nos aproximar da imparcialidade, um sistema normativo adequado deverá reequilibrar os termos dessa equação. Nesse sentido, a solução imparcial (busca da lei mais próxima, de uma perspectiva neutra) deve ser a regra geral e a solução parcial (invocação da ordem pública do próprio sistema, de modo a afastar a aplicação do direito estrangeiro inicialmente designado e aplicar o próprio direito) deve constituir a exceção. Apenas desse modo é possível contrabalançar, em parte, a tendenciosidade natural do juiz em favor da lei do foro e de seus valores.

Um desenvolvimento mais recente da teoria da ordem pública também pode ser relacionado à ideia de imparcialidade cosmopolita: trata-se da ideia de ordem pública de proximidade, segundo a qual a intensidade da rejeição do direito estrangeiro deve depender de quão próximas do foro estejam situadas as partes ou a relação jurídica ${ }^{331}$. Essa construção teórica e sua possível relação com os parâmetros cosmopolitas serão analisadas no próximo item.

\footnotetext{
${ }^{328}$ Veja-se: FÉRNANDEZ ROZAS, José Carlos; LORENZO, Sixto Sánchez. Op. cit., p. 147. Para um relato pormenorizado da discussão doutrinária entre, de um lado, aqueles que defenderam que a ordem pública é uma regra e, de outro, aqueles que sustentaram tratar-se de exceção, veja-se: DOLINGER. Jacob. A evolução da ordem pública no Direito Internacional Privado. Tese apresentada para o concurso à cátedra de Direito Internacional Privado da Faculdade de Direito da UERJ. Rio de janeiro, 1979, pp. 50-56.

${ }^{329}$ PILLET, Antoine. De l'ordre public en Droit International Privé, 1929, p. 426, apud DOLINGER. Jacob. A evolução da ordem pública no Direito Internacional Privado. Tese apresentada para o concurso à cátedra de Direito Internacional Privado da Faculdade de Direito da UERJ. Rio de janeiro, 1979, p. 51.

${ }^{330}$ DOLINGER, Jacob. Direito Internacional Privado - Parte Geral. Rio de Janeiro: Forense, 2011, 10 a ed., p. 429.

331 Veja-se: DOLINGER, Jacob. Direito Internacional Privado - Parte Geral. Rio de Janeiro: Forense, 2011, $10^{\text {a }}$ ed., pp. 400-401. Obviamente, a ideia de proximidade não é meramente geográfica, dizendo respeito a vínculos de diversas naturezas.
} 


\section{INTENSIDADE DA APLICAÇÃO DA ORDEM PÚBLICA EM FUNÇÃO DA PROXIMIDADE COM O FORO}

A noção de ordem pública de proximidade ${ }^{332}$ deriva da relatividade da ordem pública e da necessidade de sua apreciação in concreto - o estudo das circunstâncias concretas do caso compreende a verificação do grau de intensidade dos vínculos que este possui com a ordem jurídica do foro ${ }^{333}$. Sendo assim, como bem sintetiza Hélène Gaudemet-Tallon, "se tais vínculos são tênues, a exceção da ordem pública intervirá raramente; se, ao contrário, os vínculos são intensos, aí haverá mais razões para opor, caso apropriado, a ordem pública do foro" ${ }^{\text {334. }}$.

O Código de Direito Internacional Privado da Bélgica, instituído pela lei de 16 de julho de 2004, consagra essa ideia em seu art. 21, ao afirmar que a apreciação da incompatibilidade com a ordem pública deve levar em conta a intensidade da conexão da situação com a ordem jurídica belga, bem como a gravidade dos efeitos que produziria a aplicação do direito estrangeiro em questão:

\section{"Exceção da ordem pública}

Art. 21. A aplicação de um dispositivo do direito estrangeiro designado pela presente lei é descartada na medida em que produza um efeito manifestamente incompatível com a ordem pública.

Tal incompatibilidade é apreciada levando-se em conta, notadamente, a intensidade da conexão da situação com a ordem jurídica belga e a gravidade do efeito que produziria a aplicação de tal direito estrangeiro.

Uma vez que um dispositivo do direito estrangeiro não seja aplicado em razão dessa incompatibilidade, aplica-se um outro dispositivo pertinente

\footnotetext{
${ }^{332}$ A noção de ordre public de proximité, dos autores belgas e franceses, guarda semelhança com a noção alemã de Innenbezichung ou Inlandsbezichung. Veja-se: GAUDEMET-TALLON, Hélène. Op. cit., p. 424; e CARLIER, Jean-Yves. Quan l'ordre public fait désordre - Pour une interpretatión nuancée de l'ordre public de proximité en droit international privé - À propôs de deux arrêts de cassation relatifs à la polygamie et à la répudiation, Revue Générale de Droit Civil Belge, 2008, pp. 526-527, onde faz ainda referência à seguinte obra: JOUBERT, Natalie. La notion de liens suffisants avec l'ordre juridique (Inlandsbezichung) en droit international privé. Paris: Litec, 2007.

${ }^{333}$ GAUDEMET-TALLON, Hélène. Op. cit., p. 425.

${ }^{334}$ Idem. Tradução livre. No mesmo sentido, ainda: FÉRNANDEZ ROZAS, José Carlos; LORENZO, Sixto Sánchez. Op. cit., p. 146.
} 
desse direito ou, em caso de necessidade, do direito belga" ${ }^{335}$ [grifos nossos].

A primeira câmara civil da Cour de Cassation francesa aplicou o conceito de ordem pública de proximidade no caso $\mathrm{n}^{\mathrm{o}} 764$, de 10 de maio de $2006^{336}$. A questão envolvia uma investigação de paternidade proposta, na França, por uma mulher de nacionalidade algeriana, que havia dado à luz uma criança também algeriana, em solo algeriano. Por força do Direito Internacional Privado francês, a lei algeriana deveria reger a filiação, porquanto era essa a lei pessoal da mãe na data de nascimento da filha. Ocorre que o direito algeriano não permite o reconhecimento da filiação natural. Decisão de grau inferior, da corte de apelação de Versalhes, havia determinado que essa proibição era contrária à ordem pública francesa, pois violava a igualdade entre filhos legítimos e naturais. No entanto, a Cour de Cassation entendeu diferentemente, cassando a decisão e mantendo a vedação imposta pela lei algeriana, uma vez que não se tratava de criança de nacionalidade francesa ou residente na $\operatorname{França~}^{337}$, devendo ser respeitada a lei pessoal da mãe - o direito algeriano. Assim, entendeu-se que os elementos de conexão do caso com o direito francês eram insuficientes para permitirem o uso da exceção da ordem pública local.

É, à primeira vista, interessante a ideia de Jean-Yves Carlier, no sentido de que a ordem pública não seria tanto uma exceção ao princípio da proximidade, mas sim um retorno a este, uma vez que o descarte da lei estrangeira (ou dos efeitos de um ato estrangeiro) frequentemente se dá porque a ordem jurídica estrangeira é menos próxima à situação que a ordem jurídica do foro ${ }^{338}$.

Mas não concordamos inteiramente com o autor, pois conseguimos vislumbrar hipóteses de descarte de uma lei estrangeira que seja a mais próxima à situação, quando a solução por esta dada importar violações gravíssimas, inadmissíveis, a um valor

\footnotetext{
${ }^{335}$ Loi du 16 juillet 2004 portant le Code de Droit International Privé. Tradução livre.

${ }^{336}$ Première chambre civile, 10 mai 2006, Bull. $n^{\circ} 226$.

${ }^{337}$ Em caso anterior, de 10 de fevereiro de 1993, a primeira câmara civil da Cour de Cassation havia decidido que "se as leis estrangeiras que proíbem o estabelecimento da filiação natural não são, em princípio, contrárias à concepção francesa de ordem pública internacional, outro será o caso uma vez que tais leis tenham como efeito privar uma criança francesa ou habitualmente residente na França do direito de estabelecer sua filiação". Cf. FOYER, Jacques. Note sur Cass. Fr., 10 février 1993, Revue Critique de Droit International Privé, 1993, p. 621.

${ }^{338}$ CARLIER, Jean-Yves. Op. cit., p. 526.
} 
verdadeiramente importante do foro ou da sociedade internacional. Nesse caso, a ordem pública levaria a uma solução diversa daquela apontada pela proximidade. O que há, portanto, é uma aplicação conjunta da proximidade e da ordem pública, a primeira condicionando (limitando ou ajudando a justificar, conforme o caso) a aplicação da segunda, porém não uma completa assimilação de uma pela outra.

A ordem pública de proximidade permite tanto a defesa de valores importantes do foro quanto o respeito a valores estrangeiros diferentes ${ }^{339}$ - em hipóteses nas quais, mesmo havendo contrariedade a um valor que a ordem jurídica do foro reputa importante, a situação não guarda conexão considerável com esta última.

Observe-se que o cosmopolitismo empírico-analítico pressupõe a aferição de graus de vinculação com contextos sociais diversos, atenuando a arbitrariedade de distinções absolutas do tipo "nacional/estrangeiro", cumprindo estimar a posição relativa dos fatos e agentes (cf. item I.2.5.1, supra). A ordem pública de proximidade é, exatamente, um instrumento dessa postura metodológica de nuances, na medida em que propugna a limitação da intensidade da aplicação da ordem pública do foro, sempre que este não se encontrar suficientemente próximo à relação jurídica, não havendo grau de vinculação bastante.

Conforme já abordado, julgar com imparcialidade, na linha do pensamento de Smith, exige que nos transportemos para uma posição imaginária, que não é a nossa posição, tampouco a posição do outro; sendo antes uma posição intermediária a partir da qual seria possível julgar com certa isenção ${ }^{340}$. Especificamente no contexto internacionalizado, isso significa não tomar como ponto de partida uma perspectiva nacional parcial. Condicionar a aplicação da ordem pública ao critério da proximidade atende à postura imparcial cosmopolita, na medida em que se trata de exigir uma legitimação externa, do ponto de vista argumentativo, para justificar a imposição dos valores nacionais inscritos na ordem pública do foro. Desse modo, onde não houver proximidade suficiente com a ordem jurídica do foro, o âmbito de aplicação da exceção da ordem pública (ou, em outras palavras, dos valores parciais do foro) deve ser reduzido. Empreende-se, assim, uma prudente autocontenção cosmopolita.

\footnotetext{
${ }^{339}$ Veja-se: GAUDEMET-TALLON, Hélène. Op. cit., p. 428.

${ }^{340}$ Veja-se o item I.2.4, supra.
} 
Registre-se um alerta: a ordem pública de proximidade pode ser utilizada, erroneamente, para afastar uma norma estrangeira que prejudique a parte nacional, domiciliada ou residente no foro, eleita como predileta pelo juiz. Argumentando que a situação encontra-se próxima ao foro em virtude de um desses fatores - nacionalidade, domicílio ou residência (ou de todos), de modo a aplicar a exceção da ordem pública e afastar a norma estrangeira competente, as cortes podem camuflar uma tendenciosidade provinciana em favor da parte local.

Isso seria, em nossa opinião, uma clara desvirtuação do instituto, pois o critério da proximidade, no contexto ora examinado, serve para balizar a intensidade da aplicação da exceção da ordem pública, sendo o papel desta última proteger valores fundamentais do foro, e não estabelecer privilégios injustificáveis para os locais. Remeta-se, aqui, ao parâmetro cosmopolita de tratamento do indivíduo enquanto unidade fundamental de consideração moral, que impõe que nosso senso de justiça não faça distinções arbitrárias com base na nacionalidade (cf. item I.2.5.2, supra).

\section{ORDEM PÚBLICA VERDADEIRAMENTE INTERNACIONAL}

Outro desenvolvimento da teoria da ordem pública no Direito Internacional Privado que pode ser relacionado ao cosmopolitismo é a noção de ordem pública verdadeiramente internacional. Como aponta Dolinger, há uma ordem pública de terceiro grau (adicionalmente à ordem pública de direito interno - primeiro grau; e à ordem pública de Direito Internacional Privado no sentido tradicional - segundo grau), a consagrar determinados princípios universais, servindo aos mais altos interesses da humanidade ${ }^{341}$.

No julgamento do caso Boll, pela Corte Internacional de Justiça - CIJ (1958) ${ }^{342}$, o grande internacionalista e juiz Hersch Lauterpacht, com vistas a verificar a adequação da aplicação de medida protetiva por parte das autoridades suecas em relação a Elisabeth Boll, criança de nacionalidade holandesa residente na Suécia, afirmou:

\footnotetext{
${ }^{341}$ DOLINGER, Jacob. Ordem pública mundial: ordem pública verdadeiramente internacional no Direito Internacional Privado, Revista de Informação Legislativa, $\mathrm{n}^{\circ}$ 90, 1986, p. 211. Veja-se, também, DOLINGER, Jacob. Contratos e obrigaç̃̃es no Direito Internacional Privado. Rio de Janeiro: Renovar, 2007, pp. 170-190.

${ }^{342}$ CIJ, Caso concernente à aplicação da Convenção de 1902 sobre guarda de menores (Holanda v. Suécia), 28.11.1958.
} 


\begin{abstract}
"Claramente, não é a noção sueca de ordre public que fornece o parâmetro exclusivo neste contexto. A resposta é que a noção de ordre public - ou public policy - sendo um conceito jurídico geral, deve ter seu conteúdo estabelecido da mesma forma que qualquer outro princípio geral de direito no sentido do Artigo 38 do Estatuto [da CIJ], nomeadamente, em referência à prática e experiência dos direitos domésticos do países civilizados, nesse campo." ${ }^{343}$
\end{abstract}

O raciocínio de Lauterpacht parece corroborar a ideia de que existe uma ordem pública maior, verdadeiramente internacional, apta a servir de parâmetro para avaliar a adequação (ou não) da aplicação de determinada ordem pública local. Observe-se, contudo, que o contexto do caso Boll era o de uma corte internacional verificando o cumprimento, por parte da Suécia, das obrigações assumidas por esta enquanto Estado Parte da Convenção de Haia de 1902 sobre guarda de menores - ou seja, tratava-se de controvérsia de Direito Internacional Público. Não obstante, a discussão envolveu um tratado de Direito Internacional Privado, que buscou uniformizar a regra de conexão em matéria de guarda (optando pela lei nacional) - daí nosso interesse redobrado nessa posição de Lauterpacht.

Outro autor, Henri Rolin, já defendia em 1960 que a ordem pública verdadeiramente internacional pode não apenas impedir a aplicação de uma norma estrangeira, como também suplantar uma norma de ordem pública interna ${ }^{344}$.

Assim sendo, a ordem pública verdadeiramente internacional no Direito Internacional Privado parece importar as seguintes diretivas: (i) a utilização da técnica da ordem pública para proteger não somente a sociedade local, como também outras sociedades, em espírito de solidariedade; (ii) a tomada em consideração das ordens públicas estrangeiras relacionadas à situação; e (iii) a atenção a alguns princípios mais

\footnotetext{
${ }^{343}$ CIJ, Caso concernente à aplicação da Convenção de 1902 sobre guarda de menores (Holanda v. Suécia), 28.11.1958, p. 41. Tradução livre.

${ }^{344}$ ROLIN, Henri. Vers un ordre public réelement international. In: Hommage d'une generatión de juristes au Président Basdevant, 1960, p. 441, apud DOLINGER, Jacob. Ordem pública mundial: ordem pública verdadeiramente internacional no Direito Internacional Privado, Revista de Informação Legislativa, $\mathrm{n}^{\circ}$ 90, 1986, p. 212.
} 
elevados, relativos aos interesses comuns da humanidade, ainda que isso altere, em determinados casos, o escopo daquilo que se entende por ordem pública local ${ }^{345}$.

Parece haver certa relação entre a ordem pública verdadeiramente internacional do Direito Internacional Privado e a ideia de jus cogens do Direito Internacional Público, consagrada no art. 53 da Convenção de Viena de Direito dos Tratados de $1969^{346}$ (normas aceitas e reconhecidas pela comunidade internacional dos Estados como um todo como não passíveis de derrogação, a não ser por norma ulterior de direito internacional geral de igual hierarquia) ${ }^{347}$. Sendo certo que a questão da determinação de seu conteúdo permanece problemática, destaque-se a constatação de Casella, no sentido de que "a consolidação do conceito de normas imperativas de direito internacional geral e da aceitação deste se está fazendo irreversível"348. E, como aponta Pierre-Marie Dupuy, a imperatividade do jus cogens introduz uma lógica de ordem pública na ordem jurídica internacional ${ }^{349}$.

Outro autor, Pierre Lalive, aponta duas ordens de dificuldades: (i) quanto ao objeto, a própria existência de uma ordem pública transnacional teria sido contestada por muitos; e (ii) quanto à natureza, devido ao caráter interdisciplinar e abrangente da mesma - tocando tanto o Direito Internacional Privado quanto o Direito Internacional Público e referindo-se a uma grande variedade de matérias - contratos, processo, direito da concorrência, direito administrativo, direitos humanos, legislação cambial etc ${ }^{350}$.

Não obstante, o autor conclui (escrevendo já em $1986^{351}$, diga-se) que a observação da prática, seja no que concerne aos juízes estatais ou aos árbitros, não permite negar a existência de uma ordem pública transnacional ${ }^{352}$. Em particular, a imprecisão quanto ao conteúdo da ordem pública verdadeiramente internacional e sua fluidez não são

\footnotetext{
${ }^{345}$ Em sentido semelhante: DOLINGER, Jacob. Ordem pública mundial: ordem pública verdadeiramente internacional no Direito Internacional Privado, Revista de Informação Legislativa, nº 90, 1986, p. 232. ${ }^{346}$ Promulgada no Brasil pelo Decreto $n^{\circ} 7.030$, de 14 de dezembro de 2009 (com 40 anos de atraso).

${ }^{347}$ Sobre o conceito de jus cogens, veja-se: RODAS, João Grandino. Jus cogens em Direito Internacional, Revista da Faculdade de Direito da Universidade de São Paulo, vol. 69, no 2, 1974, pp. 125-136; e CASELLA, Paulo B.. Fundamentos do Direito Internacional pós-moderno. São Paulo: Quartier Latin, 2008, pp. 721-829.

348 Idem, p. 771.

${ }^{349}$ DUPUY, Pierre-Marie. L'unité de l'ordre juridique international. Recueil des Cours, t. 297, 2002, p. 281.

${ }^{350}$ LALIVE, Pierre. Ordre public transnational (ou réellement international) et arbitrage international, Révue d'Arbitrage, 1986, p. 361.

${ }^{351}$ Portanto, anteriormente à queda do muro de Berlim, em 1989, e à forte onda de transnacionalização da vida ocorrida nas últimas duas décadas.

${ }^{352}$ LALIVE, Pierre. Ordre public transnational (ou réellement international) et arbitrage international, Révue d'Arbitrage, 1986, p. 363.
} 
argumentos válidos para se objetar sua existência, uma vez que estas também são características marcantes da ordem pública clássica do Direito Internacional Privado ${ }^{353}$.

A ordem pública verdadeiramente internacional frequentemente coincide com a ordem pública internacional do Estado no sentido clássico, ambos os conceitos nutrindo-se mutuamente, porém não há identidade completa - assim como os valores e interesses fundamentais de um Estado nem sempre são idênticos aos valores e interesses da sociedade internacional como um todo, a noção de ordem pública internacional do Estado tampouco se confunde com a de ordem pública verdadeiramente internacional ${ }^{354}$.

De todo modo, também a ordem pública verdadeiramente internacional deve ser aplicada com prudência e parcimônia, à semelhança do que ocorre com a ordem pública de Direito Internacional Privado, no sentido tradicional ${ }^{355}$. Isso se dá porque é preciso respeitar as diferenças legítimas dos diversos sistemas jurídicos estatais, assim como a vontade das partes - onde a estas é dado pactuar.

Um dos melhores exemplos dos quais se tem notícia de aplicação concreta do conceito, no Direito Internacional Privado, deu-se no julgamento do caso Kuwait Airways Co. v. Iraqi Airways Co. et $a l^{356}$, pela House of Lords, do Reino Unido, em 2002. O pano de fundo do caso era a invasão e anexação do Kuwait pelo Iraque, em 1990, contexto em que foi editada a Resolução $\mathrm{n}^{\mathrm{o}} 369$ do Conselho do Comando Revolucionário do Iraque, publicada em 17.09.1990, a qual determinou a dissolução da sociedade Kuwait Airways Co. e a transferência de todos os seus bens para a Iraqi Airways Co., incluindo uma série de aeronaves. A House of Lords considerou que tal resolução não poderia ser observada em seu julgamento, na medida em que violava a ordem pública.

Registrando que as Resoluções $n^{\circ}$ 660, 661, 662, 674 e 678 do Conselho de Segurança da ONU haviam condenado a invasão iraquiana ao Kuwait e o confisco de bens, Lord Nicholls of Birkenhead afirmou que reconhecer a resolução confiscatória iraquiana seria contrário à ordem pública do direito inglês ${ }^{357}$. É digno de nota que o magistrado inglês afirmou em seu voto que "tornando-se as nações cada vez mais interdependentes, a

\footnotetext{
${ }^{353}$ Idem, p. 364.

${ }^{354}$ Ibid, p. 368.

355 Veja-se: LALIVE, Pierre. Ordre public transnational (ou réellement international) et arbitrage international, Révue d'Arbitrage, 1986, p. 371.

356 [2002], UKHL $19-16.05 .2002$.

357 [2002], UKHL 19, itens 20-29.
} 
necessidade de reconhecer e aderir a parâmetros de conduta estabelecidos pelo direito internacional torna-se crescentemente importante" ${ }^{\text {358. }}$.

Há passagens ainda mais interessantes no voto de outro juiz, Lord Steyn. Observando que "é amplamente aceito que os princípios da Carta das Nações Unidas que proíbem o uso da força possuem caráter de jus cogens", e tomando em consideração o efeito vinculante das resoluções do Conselho de Segurança da ONU aplicáveis, o magistrado concluiu que conferir efeitos à Resolução $n^{0} 369$ seria contrário à ordem pública doméstica inglesa ${ }^{359}$. Mas Lord Steyn acrescentou, ainda, outro argumento:

"Essa conclusão sobre a ordem pública inglesa não reflete uma perspectiva insular. Nossa ordem pública doméstica sobre o status da Resolução 369 não está sozinha. Em anos recentes, particularmente como resultado da pesquisa francesa, princípios de ordem pública internacional (l'ordre public veritablement international) desenvolveram-se em relação a temas como tráfico de drogas, tráfico de armas, terrorismo, e assim por diante. [...] A ordem pública que condena as violações flagrantes do Direito Internacional Público por parte do Iraque é mais uma ilustração dessa ordem pública verdadeiramente internacional em ação"360.

Desse modo, a House of Lords utilizou o argumento da ordem pública em sua vertente verdadeiramente internacional para desconsiderar uma norma iraquiana que seria, de outro modo, aplicável por força das normas inglesas de Direito Internacional Privado. Não somente os valores fundamentais da ordem jurídica inglesa justificaram a decisão, como também interesses elevados da comunidade internacional - a proibição do uso da força e do confisco de bens.

A ordem pública verdadeiramente internacional pode cumprir, no Direito Internacional Privado, o papel do mínimo universal referido por teóricos do cosmopolitismo (veja-se o item I.2.5.4, supra), que permite a própria existência da estrutura básica de respeito à diferença. Assim, em regra, respeitar-se-ão valores e soluções diferentes dos próprios, ainda que com eles não se concorde, sempre que a situação

\footnotetext{
358 [2002], UKHL 19, item 28. Tradução livre.

359 [2002], UKHL 19, item 114. Tradução livre.

360 [2002], UKHL 19, item 115. Tradução livre.
} 
revelar-se mais conectada a outro sistema jurídico, que os preveja. O contraponto é que tais valores sejam excepcionalmente rechaçados, quando atentarem flagrantemente contra os mais altos interesses da humanidade, protegendo-se assim determinados princípios universais.

Esses altos interesses, ademais, também devem condicionar a concepção do foro acerca de sua própria ordem pública, que os deve respeitar e promover. Dessa forma, alguns princípios mínimos universais devem limitar tanto a aceitação de valores estrangeiros quanto os contornos dos próprios valores ou interesses traduzidos na ordem pública do foro. É verdade, porém, que o estabelecimento do conteúdo de tais princípios universais e sua colocação em prática permanecem problemáticos. Como recorda Dolinger:

"a consecução de uma ordem pública verdadeiramente internacional,
apesar de alguns sucessos já anteriormente mencionados, irá requerer
grande esforço mútuo e uma extraordinária boa vontade por um período de
tempo relativamente extenso" 361 .

De todo modo, é sintomático que na conclusão desse artigo seminal, no Brasil, sobre o tema, o mesmo autor mencione expressamente o direito cosmopolita de Kant - o que é de especial interesse para os fins do presente estudo -, para logo em seguida afirmar:

\begin{abstract}
"Todos os sistemas jurídicos internos - abrangendo suas regras sobre o conflito de leis, sobre a ordem pública, tanto a puramente interna como a de efeitos internacionais -, juntamente com os fundamentos morais e filosóficos imanentes em todas as instituições jurídicas, todos dependem da manutenção de um respeito universal por uma ordem pública mais elevada, a ordem pública da comunidade internacional” ${ }^{\text {362. }}$.
\end{abstract}

Com efeito, enxergamos no marco teórico cosmopolita um importante potencial transformador da teoria jurídica, rumo a uma condição de maior compreensão mútua entre os direitos estatais, condição esta fundada, em última análise, no respeito à ordem pública verdadeiramente internacional.

${ }^{361}$ DOLINGER, Jacob. Ordem pública mundial: ordem pública verdadeiramente internacional no Direito Internacional Privado, Revista de Informação Legislativa, nº 90, 1986, p. 223.

362 Idem, p. 232. 


\section{ORDEM PÚBLICA E DETERMINAÇÃo DA LEI APLICÁVEL: JURISPRUDÊNCIA BRASILEIRA ${ }^{363}$}

\subsection{Regime de bens}

Na Apelação Cível no $70006130173^{364}$, julgada pela $8^{\mathrm{a}}$ Câmara Cível do Tribunal de Justiça do Estado do Rio Grande do Sul, em 14.08.2003, a ordem pública foi utilizada como um dos argumentos aptos a determinar a improcedência de ação declaratória, a qual buscava a afirmação de que o regime de bens entre a Apelada e o falecido pai dos Apelantes seria o da separação de bens.

O Desembargador Relator, Rui Portanova, analisou uma série de fatores de conexão (domićlio dos cônjuges, nacionalidade, local de aquisição dos bens inventariados e sociedade empresária constituída pelos cônjuges no Brasil), para decidir pela aplicabilidade da lei brasileira sobre regime de bens (Código Civil de 1916), confirmando a solução da regra de conexão do art. $7^{\circ}, \S 4^{\circ}$, da Lei de Introdução - lei do domicílio. Notese que a lei brasileira estabelecia como supletivo o regime da comunhão, e não da separação de bens.

Digno de nota é que o magistrado afirmou que mesmo que a legislação aplicável fosse a da Áustria, a ordem pública brasileira impediria o reconhecimento da separação de bens, na medida em que os cônjuges não haviam eleito expressamente tal regime, haviam vivido cerca de 44 anos juntos ("quase uma vida") e seus bens haviam sido adquiridos na constância do casamento. Nas palavras do Relator:

\footnotetext{
"E, independentemente da discussão a respeito da legislação aplicável (se a austríaca ou a brasileira), deve o julgador, na aplicação da lei, atender aos fins sociais a que ela se dirige e ao bem comum (art. $5^{\circ}$ da LICC).
}

\footnotetext{
363 Os procedimentos de homologação de sentenças estrangeiras e de concessão de exequatur a cartas rogatórias são ricos em discussões concernentes à ordem pública internacional; mas não serão aqui examinados, tendo em vista que o que é de interesse para este estudo é a atuação da ordem pública no contexto do método conflitual - determinação da lei aplicável.

${ }^{364}$ TJRS, $8^{\text {a }}$ Câmara Cível, Apelação Cível no 70006130173, 14.08.2003, julgamento unânime.
} 
A própria incorporação do direito alienígena pode sofrer restrições (regra odiosa) conforme os preceitos de ordem pública e valores sociaiseconômicos da Nação.

Todas estas questões foram trazidas para dizer que seria antijurídico e desumano deixar Margarita desamparada depois de viver quase uma vida (44 anos) com seu marido. Inegável é o efeito jurídico-moral e econômicoafetivo da relação conjugal estabelecida."

Nesse julgado, a ordem pública parece ter sido invocada corretamente. Realmente, em nossa opinião, o desamparo econômico da viúva, após 44 anos de casamento, feriria gravemente um valor fundamental da ordem jurídica brasileira, extraído da sensibilidade média da sociedade, tendo em vista que o regime patrimonial da separação não havia sido expressamente pactuado pelos cônjuges.

\subsection{Casamento no exterior de pessoa desquitada no Brasil}

No Recurso Especial no 34.093-0/RJ ${ }^{365}$, julgado em 11.10.1994, a $3^{\mathrm{a}}$ Turma do Superior Tribunal de Justiça (STJ) impediu o registro, no Brasil, de casamento celebrado no exterior por brasileiros, um dos quais era desquitado à época do matrimônio, o que se traduziria em impedimento dirimente absoluto, segundo a legislação brasileira.

A $5^{\text {a }}$ Câmara Cível do Tribunal de Justiça do Estado do Rio de Janeiro, no caso, havia determinado a possibilidade do registro, pois a alteração da ordem social brasileira no sentido de admitir o divórcio, em seu entender, passou a dar condições de eficácia ao ato. No entanto, a $3^{\mathrm{a}}$ Turma do STJ interpretou de modo diferente. Mesmo o registro tendo sido pedido após a introdução do divórcio no Brasil, o Ministro Costa Leite, acompanhado à unanimidade, afirmou:

${ }^{365}$ STJ, $3^{\text {a }}$ Turma, REsp n ${ }^{\text {o } 34.093-0 / R J, ~ 11.10 .1994, ~ j u l g a m e n t o ~ u n a ̂ n i m e . ~}$ 
"Deveras, a introdução do divórcio no Brasil veio a permitir a sucessividade de casamentos, não alcançando, no entanto, a hipótese de que aqui se cuida. Se, ao tempo do casamento realizado no exterior, havia impedimento dirimente absoluto, segundo a lei brasileira, e por isso mesmo o ato não era apto a produzir efeitos no país, na conformidade do disposto no art. 17 da LICC [atual LINDB], não se há de admitir, por razão de boa lógica jurídica, que, desaparecido o impedimento, em face da superveniência da Lei do Divórcio, haja se tornado eficaz, pois tanto implicaria reconhecer possível simultaneidade de casamentos."

Entendemos que essa posição do STJ foi completamente equivocada, devendo ter sido mantida a orientação do julgamento de $2^{\circ}$ grau do Rio de Janeiro. Em primeiro lugar, observe-se que o $\S 1^{\circ}$ do art. $7^{\circ}$ da Lei de Introdução estabelece que "realizando-se $o$ casamento no Brasil, será aplicada a lei brasileira quanto aos impedimentos dirimentes e às formalidades da celebração". A contrario sensu, aplicar-se-á a lei estrangeira, no que concerne aos impedimentos, quando se tratar de matrimônio celebrado alhures, como ocorreu no caso em tela. Nesse sentido, os impedimentos da lei brasileira, por si só, não afetam um casamento celebrado no exterior.

Quanto ao argumento da exceção da ordem pública (art. 17 da Lei de Introdução), o julgado deixou de observar que esta tem como uma de suas características centrais a contemporaneidade ${ }^{366}$, devendo ser auscultada a ordem social vigente no momento da decisão, e não aquela da época do matrimônio. Além disso, o tribunal encontrava-se diante de uma situação regularmente consolidada no exterior, o que implicaria um efeito atenuado da ordem pública $^{367}$.

Por fim, a existência ou não da simultaneidade de casamentos poderia ser verificada no caso concreto e, conforme fosse, resultar na eficácia do segundo casamento apenas após a aceitação do divórcio no Brasil e a conversão do desquite em divórcio. Entretanto, foi infeliz a solução de se negar, peremptoriamente, a possibilidade de reconhecimento do casamento celebrado no passado, no exterior, por pessoa desquitada. Desse modo, a vedação do registro foi de todo inapropriada, negando-se reconhecimento a um ato

\footnotetext{
${ }^{366}$ Veja-se o item IV.1, supra.

${ }^{367}$ Veja-se o item IV.1, supra.
} 
existente, válido, e detentor de condições de eficácia em território nacional, por não mais ferir nossa ordem pública vigente à época do registro.

\subsection{Dívida de jogo contraída no exterior}

Nos Embargos Infringentes na Apelação Cível $\mathrm{n}^{\mathrm{o}} 44.921^{368}$, julgados pela $2^{\mathrm{a}}$ Câmara Cível do Tribunal de Justiça do Distrito Federal e Territórios, em 14.10.1998, a ordem pública de Direito Internacional Privado permeou a discussão sobre a exigibilidade de dívida de jogo, contraída no exterior, pelo Embargante. Este argumentou que a cobrança de dívida de jogo feriria a ordem pública (art. 17 da Lei de Introdução), porquanto o art. 1.477 do Código Civil de 1916, então vigente, estabelecia que as dívidas de jogo ou aposta não obrigam a pagamento.

A Desembargadora Adelith Lopes, cuja opinião foi seguida pela maioria, observou que o direito brasileiro, no art. $9^{\circ}$ da Lei de Introdução, elegeu o locus celebrationis como elemento de conexão e que, assim, a lei brasileira só poderia ser aplicada à relação contratual entre as partes, que se dera no estrangeiro, se houvesse afronta à ordem pública (art. 17 da mesma lei).

Ocorre que o jogo é permitido nos EUA, país onde ocorreram os fatos. Nesse contexto, a magistrada concluiu que "referendar o enriquecimento ilícito perpetrado pelo embargante representaria afronta muito mais significativa [à ordem pública] do que admitir a cobrança da dívida de jogo"; autorizando, portanto, a cobrança.

No julgado ora examinado, a ordem pública foi invocada não para afastar a aplicação da lei estrangeira, mas sim para referendá-la, observando-se um saudável respeito ao tratamento legal dado ao jogo pelo ordenamento estrangeiro, distinto daquele previsto no ordenamento brasileiro. É de se aplaudir a decisão, que traduziu tolerância típica do espírito cosmopolita.

\footnotetext{
${ }^{368}$ TJDFT, $2^{\text {a }}$ Câmara Cível, Embargos Infringentes na Apelação Cível nº 44.921, 14.10.1998, julgamento por maioria.
} 
A $5^{\text {a }}$ Câmara Cível do Tribunal de Justiça do Estado do Paraná, na Apelação Cível $n^{\text {o }} 129.332-1^{369}$, julgada em 22.10.2002, decidiu em sentido idêntico, porém dessa vez para manter a posição do juiz a quo. Afirmou o Desembargador Relator, Domingos Ramina, acompanhado à unanimidade, que:

“... sendo contraída em país cuja legislação admite e regula a prática de jogo, a dívida oriunda de jogo de azar é lícita e pode ser cobrada no Brasil, com base no art. $9^{\circ}$ da LICC (para qualificar e reger as obrigações, aplicarse-á a lei do país em que se constituírem), ou seja, lex loci celebrationis, lei do lugar da celebração -, pois a ofensa aos bons costumes, no caso, seria o enriquecimento ilícito do brasileiro que buscou cassino regularmente instalado no país [Argentina] onde se admite o jogo de azar, endividou-se, emitiu cheque, mas nega-se ao pagamento."

Na Apelação Cível no $171.008-3^{370}$, julgada pela $9^{a}$ Câmara Cível do Tribunal de Justiça do Estado do Paraná, em 16.06.2005, também se discutiu a exigibilidade de dívida de jogo, igualmente contraída na Argentina, onde o funcionamento de cassinos constitui atividade lícita. A sentença de primeiro grau havia determinado o afastamento do direito argentino, sob o argumento de que este ofenderia a ordem pública e os bons costumes (art. 17 da Lei de Introdução). O órgão de apelação, contudo, entendeu em sentido diverso, corretamente. Transcreva-se trecho do voto do Desembargador Relator, Ruy Cunha Sobrinho:

\footnotetext{
"Em primeiro lugar, não se pode falar em ofensa à moral e aos bons costumes se a jogatina é oficializada no país [Brasil], bancada pelo Estado por diversas formas, proibindo-se apenas o jogo explorado pela atividade privada.

Em segundo lugar, repugna a invocação da legislação brasileira (art. 1.477 do CC/1916), para subtrair-se a dívida licitamente contraída no estrangeiro, o que contraria até mesmo o interesse nacional, já que fatos desta natureza
}

\footnotetext{
${ }^{369}$ TJPR, $5^{\text {a }}$ Câmara Cível, Apelação Cível no 129.332-1, 22.10.2002, julgamento unânime.

${ }^{370}$ TJPR, $9^{a}$ Câmara Cível, Apelação Cível no ${ }^{\circ} 171.008-3,16.06 .2005$, julgamento unânime.
} 
não recomendam o turista brasileiro no exterior e trazem má fama ao país." 371

Entendimento semelhante foi esposado pela $10^{\text {a }}$ Câmara Cível do Tribunal de Justiça do Estado de Minas Gerais, no julgamento da Apelação Cível no 1.0145.04.1879738/001 372 , em 27.03.2007. No julgado, respeitou-se a permissão uruguaia ao jogo, em obediência ao art. $9^{\circ}$ da Lei de Introdução brasileira. Nesse sentido, o Desembargador Relator, Roberto Borges de Oliveira, anotou que "a divida oriunda de jogo tem natureza obrigacional e, para tal situação, o direito pátrio estatuiu como elemento de conexão a lei do local no qual foi realizado o ato jurídico [...]".

\subsection{Prazo prescricional estabelecido em lei estrangeira}

Na Apelação Cível no 409.921-8 ${ }^{373}$, julgada em 10.11.2004 pela $3^{\text {a }}$ Câmara Cível do Tribunal de Alçada do Estado de Minas Gerais, entendeu-se que prazos prescricionais estabelecidos pela lei estrangeira aplicável, diferentes dos brasileiros, não atentam contra a nossa ordem pública.

O contrato de empréstimo (Loan Agreement) celebrado entre as partes dispunha que o contrato e as notas promissórias correspondentes seriam regidos e interpretados de acordo com a lei do Estado de Nova York. Não obstante, os executados arguiram que a prescrição seria questão de ordem pública e, portanto, a lei de Nova York não poderia ser aplicada, nos termos do art. 17 da Lei de Introdução. A Desembargadora Relatora, Teresa Cristina da Cunha Peixoto, no que foi acompanhada por seus pares, rejeitou essa tese, observando o prazo prescricional da lei nova-iorquina:

\footnotetext{
${ }^{371}$ Note-se que essa posição inspirou-se na Carta Rogatória no 9.970, julgada pelo Ministro Marco Aurélio, do STF, em 18.03.2002 (antes da mudança de competência efetuada pela EC 45/2004, para o STJ). Tal julgado não será tratado aqui, pois não versou a aplicação direta da lei estrangeira, mas é emblemático no que concerne à exceção da ordem pública no Direito Internacional Privado.

372 TJMG, $10^{\mathrm{a}}$ Câmara Cível, Apelação Cível $\mathrm{n}^{\circ}$ 1.0145.04.187973-8/001372, 27.03.2007, julgamento unânime.

${ }^{373}$ Tribunal de Alçada do Estado de MG, 3a Câmara Cível, Apelação Cível nº 409.921-8, 10.11.2004, julgamento unânime.
} 


\begin{abstract}
“Assim, não entendo que, no caso em análise, a aplicação do prazo de seis anos para prescrição dos títulos exequendos, notas promissórias, estaria a ferir a ordem pública do país, sendo claramente possível a incidência de lei estrangeira ao caso sob análise, por não estar a ferir o que prescreve o art. 17 da LICC".
\end{abstract}

Em nossa visão, trata-se de posição exemplar. Tanto a aceitação da autonomia da vontade no plano internacional, por parte da Relatora, quanto o afastamento da exceção da ordem pública, no que concerne à prescrição, são exemplos de cosmopolitismo. Com efeito, o simples fato de se observar um prazo prescricional diferente, previsto na lei estrangeira aplicável ao caso, não importa, em regra, qualquer violação manifesta a princípios fundamentais do nosso ordenamento.

\title{
4.5. Autonomia da vontade e ordem pública verdadeiramente internacional
}

A $24^{\text {a }}$ Câmara de Direito Privado do Tribunal de Justiça do Estado de São Paulo decidiu, na Apelação Cível n ${ }^{\circ} 7.030 .387-8^{374}$, julgada em 18.10.2007, que um contrato de representação comercial, celebrado em 1971, nos EUA, não violava a ordem pública pelo simples fato de não conter os requisitos obrigatórios previstos no art. 27 da Lei $\mathrm{n}^{\mathrm{o}}$ $4.886 / 65$, a qual dispõe sobre os contratos de representação comercial regidos pela lei brasileira. Isso porque o contrato previa expressamente a aplicação da lei do Estado de Nova York, além da observância da regra do art. $9^{\circ}$ da Lei de Introdução também conduzir, no caso, a tal lei. Nesse sentido, afirmou o Desembargador Relator, Salles Vieira:

\footnotetext{
"Não existe a alegada afronta à ordem pública internacional, vez que, em face do direito, inclusive econômico, é salutar que as empresas brasileiras e estrangeiras, desde que o objeto do contrato seja lícito, tenham liberdade de contratar.
}

${ }^{374}$ TJSP, $24^{\mathrm{a}}$ Câmara de Direito Privado, Apelação Cível no 7.030.387-8, 18.10.2007, julgamento unânime. 
Afronta haveria se o judiciário brasileiro fosse imprevisível na solução das relações internacionais, mormente quando envolve parceria comercial entre empresas privadas.

Previsibilidade esta que se assenta no respeito às normas de direito internacional, as quais foram respeitadas no caso em exame."

É extremamente interessante que o magistrado haja incluído, em suas considerações sobre a ordem pública, o valor da previsibilidade na solução das relações internacionais, o que denota uma preocupação genuinamente internacional. Em outras palavras, trata-se de um aspecto de ordem pública verdadeiramente internacional, conceito este abordado no item IV.3, supra. Assim, para o Relator, acompanhado à unanimidade por seus pares, a falta de previsibilidade nas relações internacionais é que importaria verdadeira ofensa ao art. 17 da Lei de Introdução, e não a aplicação de lei estrangeira diferente ao caso. 


\section{CONCLUSÕES}

1) O cosmopolitismo é uma ideia muito antiga, remetendo à obra dos filósofos Cínicos (séc. IV a.C.) e Estoicos (séc. III d.C.). Enxergando-se o ser humano como um cidadão do cosmos, reconhece-se a existência de uma comunidade universal. Apesar de haver ecoado na obra de diversos autores ao longo da história, o marco teórico cosmopolita ressurgiu novamente com força nos escritos de Kant (séc. XVIII).

2) O cosmopolitismo kantiano baseia-se na ideia de hospitalidade - prerrogativa jurídica (e não meramente filantrópica), detida por qualquer ser humano, de não ser tratado como inimigo ao alcançar outro país. Sendo um cidadão do mundo, o ser humano possui direito de buscar a comunhão com todos os demais. A hospitalidade kantiana não é ilimitada, na medida em que o direito de permanência, para Kant, exigiria uma concessão especial. Note-se, todavia, que a hospitalidade é um princípio, podendo ser vista como uma ideia apta a inspirar e informar uma série de normas distintas, não necessariamente relacionadas aos direitos de visita e permanência.

3) Nas últimas décadas, o cosmopolitismo tem sido objeto de intenso estudo por variados autores. A partir da análise desses autores, surgem dois eixos essenciais: (i) a ideia de que existem obrigações universais entre os seres humanos; e (ii) a de que, apesar disso, a diversidade cultural é extremamente valiosa, havendo muito a aprender com ela. Assim, o cosmopolitismo comporta uma dualidade essencial, fundada na limitação recíproca entre universalismo e relativismo. Disso decorre que dois perigos devem ser evitados: o de um universalismo totalitário (hegemônico, soberbo), como também o de um relativismo exacerbado (indiferente, acrítico). 
4) A partir da constatação de que a governança global por meio de instituições envolve negociações extremamente difíceis, havendo ademais o risco de transformar-se em tirania global, talvez seja mais realista e prudente a aplicação de princípios de justiça cosmopolita por uma pluralidade de agentes. Sendo, ainda, os Estados, apesar de suas incontáveis imperfeições, os agentes de justiça mais bem equipados do mundo contemporâneo, mostra-se fundamental a reforma destes na direção cosmopolita.

5) A justiça baseia-se na ideia de imparcialidade, sendo especialmente útil a figura do espectador imparcial, de Adam Smith, que propõe que nos ponhamos em uma posição intermediária - que não é a nossa posição, tampouco a posição do outro, sendo antes a posição hipotética de um terceiro equidistante, apto a julgar com isenção. Assim, é possível obedecer a um senso de justiça e adequação, de forma a corrigir nossos instintos naturais egoisticamente tendenciosos. Dessa forma, devemos considerar as perspectivas alheias, buscando certo distanciamento de nós mesmos (e de nossos preconceitos), evitando um provincianismo local de valores e presunções.

6) A justiça enquanto equidade, de John Rawls, fundada na ideia do véu da ignorância, também é uma demanda por imparcialidade, ainda que fechada. Em sua concepção, devemos evitar avaliações tendenciosas por influência dos nossos próprios interesses, posição social, prioridades, excentricidades ou preconceitos individuais. Autores mais recentes, como Thomas Pogge, defendem que a nacionalidade é apenas mais uma dessas circunstâncias arbitrárias no sentido rawlsiano. Desse modo, seguindo a linha de raciocínio desses autores, a nacionalidade comum não deve importar diferenciações no que concerne à justiça.

7) Acompanhamos a visão de Amartya Sen, no sentido de que o não-provincianismo é uma precondição da justiça, sendo imprescindível a consideração dos interesses e das perspectivas de outros povos. Decidir de modo justo, no plano internacional, 
impõe que não tomemos como ponto de partida automático nossa própria perspectiva, na medida em que ela é parcial e limitada. Devemos, ao contrário, buscar a maior imparcialidade possível em relação às perspectivas nacionais parciais. Note-se, no entanto, que essa propensão a considerar argumentos vindos de fora não importa aceitar cegamente todos eles - a intolerância, por exemplo, não deve ser tolerada.

8) Das discussões acerca do cosmopolitismo, extraímos quatro parâmetros principais, aptos a lançar luzes sobre o direito e, em especial, sobre o método de determinação da lei aplicável do Direito Internacional Privado: (i) a necessidade de avanço do cosmopolitismo empírico-analítico; (ii) o tratamento do indivíduo como unidade fundamental de consideração moral; (iii) a imparcialidade aberta enquanto postulado teórico; e (iv) a busca de equilíbrio entre uma estrutura geral de respeito à diferença e um mínimo inegociável, com pretensões universais.

9) Há necessidade de avanço do cosmopolitismo empírico-analítico no âmbito do direito, pois a prática jurídica atualmente prevalecente, baseada em sistemas jurídicos nacionais consideravelmente fechados, é inapta a lidar com a complexidade dos vínculos plurais, simultâneos, multidimensionais e dinâmicos, que marcam a realidade cosmopolitizada dos dias atuais. Já tratar o indivíduo como unidade fundamental de consideração moral implica colocá-lo no centro da ordem jurídica, que deve atender às suas necessidades, em vez de se enxergar esta como instrumento para a consecução de interesses nacionais ou promoção de identidades nacionais, por vezes em detrimento da vida concreta dos seres humanos. Adotar a imparcialidade aberta como postulado teórico, por sua vez, implica um esforço no sentido de ultrapassar o traço nacionalista do ordenamento jurídico, aproximandose de uma posição de neutralidade em relação aos nacionais de diferentes países e às diversas ordens jurídicas, aprendendo e evoluindo a partir da experiência da diversidade. Por fim, o direito se insere, de maneira inequívoca, no desafio de se buscar um equilíbrio entre o particular e o universal, entre o respeito à diversidade e um mínimo universal pressuposto. 
10) O Direito Comparado é uma ferramenta para se atender à exigência cosmopolita de consideração das perspectivas de outros povos; ao passo que o Direito Internacional Privado, além de também respeitar tais perspectivas, liga-se ao tratamento adequado dos interesses de outros povos, ao buscar cuidar adequadamente do indivíduo no plano internacional.

11) O Direito Internacional Privado, como conhecemos, surgiu por volta dos sécs. XII e XIII, em meio à realidade cosmopolita das Cidades-Estados do norte da Itália, que experimentavam, nessa época, intercâmbio comercial exuberante. Assim, a disciplina se relaciona, desde seus primórdios, com a busca por adequação entre a teoria jurídica e a realidade cosmopolitizada (i.e., promoção do cosmopolitismo empírico-analítico). O Direito Internacional Privado lida com a regência da vida concreta do ser humano no plano internacional, com a abertura dos direitos nacionais a seus pares e, frequentemente, defronta-se com o dilema entre respeitar valores alheios diferentes ou promover determinados valores por nós tidos como universais. Em outras palavras, a ideia de cosmopolitismo e o Direito Internacional Privado encontram-se umbilicalmente associados.

12) Teorias, métodos e interpretações podem conduzir, no Direito Internacional privado, a duas tendências opostas: uma provinciana - insular, autocrática, arrogante, cega a preocupações internacionais; e outra cosmopolita - pluralista, tolerante, respeitadora da diversidade e atenta às exigências da sociedade internacional. Esta última é a própria razão de ser da disciplina e traduz-se na consciência de que, como regra geral, valores diferentes dos próprios devem ser respeitados, sempre que a relação jurídica assim exigir, e de que só assim poderá haver justiça no plano internacional.

13) Não se verifica propriamente a existência de duas espécies de justiça, completamente diferentes uma da outra, uma preocupada com a solução 
materialmente justa (justiça material) e outra concernente à atribuição do caso à ordem jurídica que lhe seja mais próxima (justiça conflitual). Todavia, no Direito Internacional Privado, deve-se evitar a busca daquilo que se entende por justiça material a todo custo, na medida em que esta se encontra permeada por valores preconcebidos, valores tais relativos no plano da validade (é preciso aperfeiçoar nossa visão a partir da experiência de outras culturas) e da adequação (valores desenvolvidos no âmbito de determinada sociedade frequentemente se revelarão inapropriados para reger casos mais proximamente conectados com outra sociedade). Em outras palavras, a busca pela justiça material pode, em verdade, camuflar uma atitude provinciana.

14) Assim é que cumpre guardar, em regra, independência entre os critérios de escolha da lei aplicável e a regulação propriamente material do assunto. Ao se buscar a lei mais próxima à relação jurídica, deve-se buscar justiça nessa determinação aspecto mediato - o que não necessariamente conduzirá à solução material que o juiz (ou a cultura jurídica do foro de uma maneira geral) considere mais justa justiça imediata. Do contrário, privilegiar-se-ia a aplicação da lex fori, pois o juiz, em boa parte dos casos, considerará seu direito mais justo que o direito estrangeiro.

15) Defendemos que não se deve ver, no instituto da determinação da lei aplicável, qualquer conflito entre soberanias, pois a soberania de um Estado não é afetada pela resolução de uma lide entre particulares de acordo com um direito estrangeiro. Deve-se enxergar o método como focado na busca pelo direito mais apto a reger uma relação jurídica afeta a particulares - caso concreto, e não como uma concorrência abstrata entre direitos. Esta perspectiva traduz perfeitamente o parâmetro cosmopolita de tratamento do indivíduo como unidade fundamental de consideração moral, sendo os Estados e comunidades políticas vistos enquanto instrumentos. 
16) Há três orientações metodológicas principais para a determinação da lei aplicável: multilateralismo, unilateralismo e materialismo. O multilateralismo, expresso na forma de regras de conexão de inspiração savigniana, é o método adotado pela maior parte das codificações nacionais e tratados internacionais. O unilateralismo, por sua vez, remete ao método estatutário e, mais recentemente, encontrou guarida na teoria dos interesses governamentais de Currie e no lexforismo de Ehrenzweig, ambos marcados por forte provincianismo. Já o materialismo remete ao ius gentium romano e, mais recentemente, marcou a doutrina do better-law approach aplicação do melhor direito, defendida sobretudo por alguns autores estadunidenses (destacando-se Leflar e Juenger). Este último método afasta o intérprete da imparcialidade cosmopolita pois, como afirmado, ao buscar a consecução de valores materiais, o aplicador do direito tenderá a privilegiar os seus próprios, em detrimento de outros valores possíveis, estrangeiros. É preciso estar aberto, em regra, a aceitar soluções diferentes daquelas com as quais se está mais acostumado.

17) Multilateralismo, unilateralismo e materialismo nem sempre se excluem mutuamente, havendo a possibilidade de um pluralismo de métodos no Direito Internacional Privado. Nesse contexto, ao longo do séc. XX, observaram-se três modificações no multilateralismo: (i) a flexibilização das regras de conexão princípio da proximidade; (ii) a redescoberta, por parte da doutrina, da noção de lois de police; e (iii) uma maior influência de certas preocupações materiais, com o fortalecimento de algumas regras de conexão ditas substanciais.

18) $\mathrm{Na}$ medida em que as regras de conexão sempre encontraram seu fundamento básico na ideia de proximidade, o movimento de flexibilização não foi propriamente um recuo em relação ao multilateralismo, mas sua elevação a uma potência maior. Assim, a determinação da lei aplicável deve ser função do contexto fático como um todo, evitando-se a escolha inescapável de um elemento de conexão único, a prevalecer invariavelmente sobre todos os outros contatos porventura presentes. Desse modo, o princípio da proximidade atende ao cosmopolitismo empírico-analítico: ao examinar os diversos fatores de conexão de um caso, o intérprete procede a uma análise de nuances, de graus de vinculação da 
disputa com ordens sociais e jurídicas diversas, tratando-a de acordo com sua complexidade cosmopolita. O princípio, assim, evita dois reducionismos: (i) o de um nacionalismo metodológico provinciano, que aplica a lei do foro automaticamente; e (ii) o das regras de conexão rígidas, as quais, na acepção tradicional, elegiam um único elemento de conexão inescapável.

19) As lois de police, ou normas de aplicação necessária, as quais afastam o funcionamento normal do método conflitual, devem ser excepcionais, pois o abuso de sua utilização revela tendência provinciana, traduzindo uma força expansionista do ordenamento ao qual pertencem. A devida consideração das lois de police estrangeiras, somada à moderação por parte do legislador em sua utilização, bem como a uma interpretação restritiva por parte do juiz, permite que tais normas permaneçam adstritas ao seu propósito legítimo $-\mathrm{o}$ de protegerem, excepcionalmente, alguns interesses públicos essenciais, sem anular todavia a estrutura básica do multilateralismo.

20) $\mathrm{O}$ multilateralismo jamais foi alheio à importância de certos valores materiais, como comprovam os princípios tradicionais da ordem pública, da fraude à lei e da autonomia da vontade. No entanto, houve um aumento de preocupações materialistas no âmbito dos sistemas multilateralistas ao longo do séc. $\mathrm{XX}$, o que acarretou uma maior utilização de regras de conexão ditas substanciais. Tais regras, assim como a orientação materialista em geral, podem revelar uma preferência velada pelos valores do foro, devendo, portanto, constituir um último recurso, válido principalmente em atenção a princípios já consolidados na esfera internacional, como o favor negotii.

21) Embora possam multilateralismo, unilateralismo e materialismo conviver juntos em certa medida, é preciso escolher uma matriz teórica principal para a determinação da lei aplicável. Nesse sentido, o método multilateralista parece o mais apto a garantir um mínimo de imparcialidade cosmopolita. Com efeito, as 
regras de conexão, temperadas pelos princípios tradicionais da disciplina e flexibilizadas pelo princípio da proximidade, constituem um contrapeso à tendência instintiva do intérprete no sentido de aplicar seu próprio direito e/ou valores. Além disso, o multilateralismo permite a consideração dos vínculos do caso com diversos ordenamentos, respeitando assim o espírito do cosmopolitismo empírico-analítico.

22) O princípio da ordem pública é terreno fértil para uma análise cosmopolita. Tal princípio pode ser utilizado para se buscar um equilíbrio apropriado entre o particular e o universal, atentando-se para o fato de que respeitar visões diferentes não implica a aceitação cega de todos os valores oriundos de fora. O papel tradicional do princípio, previsto no art. 17 da Lei de Introdução brasileira, é, exatamente, rechaçar a solução dada pelo direito estrangeiro sempre que esta violar manifestamente valores fundamentais do foro, tidos por este como inegociáveis.

23) Por outro lado, há o risco de que se use o princípio para justificar uma simples fuga provinciana da aplicação da lei estrangeira. Para se evitar essa deturpação, deve-se sublinhar sua natureza sempre excepcional, o que resulta na necessidade de interpretá-lo restritivamente. Isso se relaciona à ideia de imparcialidade cosmopolita. Se a tendência instintiva do intérprete é privilegiar seu próprio direito e valores, a solução imparcial (busca da lei mais próxima à relação jurídica, de uma perspectiva neutra) deve ser a regra geral e a solução parcial (invocação da ordem pública do próprio sistema) deve constituir exceção. Só assim se compensa o instinto natural.

24) A teoria da ordem pública de proximidade, segundo a qual a intensidade da rejeição do direito estrangeiro deve depender de quão próximas do foro estão situadas as partes ou a relação jurídica (sendo certo que a noção de proximidade não é meramente espacial), é um instrumento, a um só tempo, do cosmopolitismo empírico-analítico e da imparcialidade cosmopolita. O cosmopolitismo empíricoanalítico deriva do fato de se analisar a intensidade dos vínculos do caso com os 
ordenamentos em jogo, enquanto elemento prejudicial à aplicação, ou não, da ordem pública. Já a exigência de um argumento externo (proximidade), para justificar a aplicação da ordem pública do foro, obedece à imparcialidade cosmopolita, importando certa autocontenção. A construção teórica, como aliás a exceção da ordem pública de uma maneira geral, também se relaciona à mediação entre o particular e o universal. Permite, assim, tanto a defesa de valores importantes do foro quanto o respeito a valores estrangeiros diferentes - em situações nas quais, mesmo havendo contrariedade a um valor do foro, os fatos não apresentam conexão considerável com este.

25) Já a teoria da ordem pública verdadeiramente internacional constata que há uma ordem pública maior, a consagrar alguns princípios universais, servindo aos mais altos interesses da humanidade. Tal ordem pública deve servir como mais um parâmetro para a aplicação (ou não) das diversas ordens públicas locais. No Direito Internacional Privado, a noção pode cumprir o papel de mínimo universal referido por autores cosmopolitas, que permite a própria existência da estrutura básica de respeito à diversidade.

26) Assim, procurou-se demonstrar que o marco teórico cosmopolita possui grande potencial transformador da teoria jurídica, sendo especialmente importante no que se refere à teoria da determinação da lei aplicável no Direito Internacional Privado. Pode-se buscar, através dele, uma condição de maior compreensão mútua entre as diversas culturas jurídicas e ordenamentos, condição esta fundada, em última análise, no respeito à ordem pública verdadeiramente internacional.

27) Por fim, note-se que as discussões sobre o cosmopolitismo encontram-se em pleno curso; sendo o propósito deste trabalho, longe de esgotar o tema aqui tratado, apenas o de explorar algumas ideias e possibilidades, a serem futuramente debatidas e aperfeiçoadas. 


\section{BIBLIOGRAFIA}

AGRAWAL, K. B.; SINGH, Vandana. Private International Law in India. Holanda: Kluwer Law International, 2010.

APPIAH, Kwame Anthony. Cosmopolitanism - Ethics in a world of strangers. Norton: Nova York, 2007.

ARAUJO, Nadia de. Direito Internacional Privado - teoria e prática brasileira. Rio de Janeiro: Renovar, 2006, $3^{\text {a }}$ ed.

ARISTÓTELES. Ética a Nicômaco (trad.: Pietro Nassetti). São Paulo: Martin Claret, 2004.

AUDIT, Bernard. Le droit international privé en quete d'universalité, Recueil des Cours, vol. 305, Leiden/Boston: Martinus Nijhoff Publishers, 2001.

BASEDOW, Jürgen; KONO, Toshiyuki. An Economic Analysis of Private International, Tübingen: Mohr Siebeck, 2006.

BASSO, Maristela. Curso de Direito Internacional Privado. Atlas: São Paulo, 2009.

BATIFFOL, Henri. Le pluralisme des méthodes em droit international privé, Recueil des Cours, v. 139, Leiden/Boston: Martinus Nijhoff Publishers, 1973, pp. 75-147.

BAXTER, William F. Choice of Law and the Federal System, Stanford Law Review, vol. $16, \mathrm{n}^{\circ} 1,1963$, pp. 1-42.

BECK-GERNSHEIM, E. Wir und die Anderen. Frankfurt am Main: Suhrkamp, 2004.

BECK, Ulrich. The cosmopolitan vision (trad. para o inglês: Ciaran Cronin). Cambridge: Polity Press, 2006.

BENHABIB, Seyla. Democratic iterations: the local, the national and the global. In: POST, Robert (ed.). Another Cosmopolitanism, the Berkeley Tanner Lectures. Nova York: Oxford University Press, 2006.

. The philosophical foundations of cosmopolitan norms. In: POST, Robert (ed.). Another cosmopolitanism - The Berkeley Tanner lectures. Nova York: Oxford University Press, 2006.

The rights of others: aliens, residents and citizens. Cambridge: Cambridge University Press, 2004. 
BERMAN, Paul S. Choice of law and jurisdiction on the Internet - Towards a cosmopolitan vision of Conflict of Laws: redefining governmental interests in a global era, The University of Pennsylvania Law Review, v. 153, 2005.

. Conflict of Laws, globalization and cosmopolitan pluralism, The Wayne Law Review, 51, pp. 1115-1145, 2005.

BOBBIO, Norberto. A era dos direitos. Rio de Janeiro: Elsevier, 2004.

BONOMI, Andrea. Le norme imperative nel diritto internazionale privato. Zurique: Schulthess, 1998.

Boggiano, Antonio. Curso de Derecho Internacional Privado - Derecho de las Relaciones Privadas Internacionales, Buenos Aires: Abeledo-Perrot, 2003.

BRILMAYER, Lea. Rights, fairness, and choice of law, Yale Law Journal, v. 98, 1989, pp. 1277-1320.

BRILMAYER, Lea; ANGLIN, Rachel. Choice of law theory and the metaphysics of the stand-alone trigger. Iowa Law Review, nº 95, 2010, pp. 1125-1178.

BROWN, Garrett Wallace. Moving from cosmopolitan legal theory to legal practice: models of cosmopolitan law. Legal Studies, v. 28, n 3, 2008, pp. 430-451.

BUCHER, Andreas. La dimension sociale du Droit International Privé, Recueil des Cours, v. 341, Leiden/Boston: Martinus Nijhoff Publishers, 2010.

CASELLA, Paulo Borba. Direito Internacional dos Espaços, São Paulo: Atlas, 2009.

Quartier Latin, 2008.

Fundamentos do Direito Internacional pós-moderno. São Paulo:

CAVERS, David F. A critique of the choice of law problem, Harvard Law Review, v. 47, $\mathrm{n}^{\circ} 2,1933$, pp. 173-208.

1965.

. The choice of law process. Ann Arbor: University of Michigan Press,

CARLIER, Jean-Yves. Quan l'ordre public fait désordre - Pour une interpretatión nuancée de l'ordre public de proximité en droit international privé - À propôs de deux arrêts de cassation relatifs à la polygamie et à la répudiation, Revue Générale de Droit Civil Belge, 2008, pp. 525-531.

COOK, Walter W. The logical and legal bases of the Conflict of Laws, Yale Law Journal, v. 33, $n^{\circ}$ 5, 1923, pp. 457-488.

CURRIE, Brainerd. Selected essays on the Conflict of Laws. Durham: Duke University Press, 1963. 
DERRIDA, Jacques. On cosmopolitanism and forgiveness (trad.: Mark Dooley e Michael Hughes). Londres e Nova York: Routledge, 2005 (edição original de 1997).

DOLINGER, Jacob. A decadência do Direito Internacional norte-americano. In: DOLINGER, Jacob. Direito e Amor. Rio de Janeiro: Renovar, 2009, pp. 155-203.

A evolução da ordem pública no Direito Internacional Privado. Tese apresentada para o concurso à cátedra de Direito Internacional Privado da Faculdade de Direito da UERJ. Rio de janeiro, 1979.

Janeiro: Renovar, 2007.

Contratos e obrigações no Direito Internacional Privado. Rio de

- Da dignidade da diferença ao moderno Direito Internacional Privado. In: DOLINGER, Jacob. Direito e Amor. Rio de Janeiro: Renovar, 2009, pp. 131144.

Direito Internacional Privado - Do princípio da proximidade ao futuro da humanidade. In: Direito e Amor. Rio de Janeiro: Renovar, 2009, pp. 145-153.

$2011,10^{\mathrm{a}}$ ed.

Direito Internacional Privado - Parte Geral. Rio de Janeiro: Forense,

. Evolution of principles for resolving conflicts in the field of contracts and torts, Recueil des Cours, v. 283, Leiden/Boston: Martinus Nijhoff Publishers, 2000.

In defense of the "General Part" principles. In: BORCHERS, Patrick; ZEKOLL, Joachim (ed.). International Conflicts of Laws for the Third Millenium: Essays in honor of Friedrich Juenger. Nova York: Transnational Publishers, 2000, pp. 23-51.

Ordem pública mundial: ordem pública verdadeiramente internacional no Direito Internacional Privado, Revista de Informação Legislativa, nº 90, 1986, pp. 205-232.

DUPUY, Pierre-Marie. L'unité de l'ordre juridique international. Recueil des Cours, vol. 297, 2002.

DWORKIN, Ronald. Taking rights seriously. Cambridge, MA: Harvard University Press, 1977.

EHRENZWEIG, Albert A. A proper law in a proper forum: a Restatement of the "Lex Fori" approach, Oklahoma Law Review, no 18, 1965, pp. 340-356.

. The Lex Fori - Basic rule in the Conflict of Laws, Michigan Law Review, vol. 58, $\mathrm{n}^{\circ}$ 5, 1960, pp. 637-688. 
FÉRNANDEZ ROZAS, José Carlos; LORENZO, Sixto Sánchez. Derecho Internacional Privado. Madrid: Thomsom Civitas, 2004, $3^{\text {a }}$ ed.

FORST, Rainer. Towards a critical theory of transnational justice. In: POGGE, Thomas W. (org.). Global justice. Malden, MA: Blackwell Publishing, 2001, pp. 169-187.

FOYER, Jacques. Note sur Cass. Fr., 10 février 1993, Revue Critique de Droit International Privé, 1993, p. 620.

FRANCESCAKIS, Phocion. Rep. Dalloz de droit international, la ed., verbete "Conflit de lois", no 137.

GAUDEMET-TALLON, Hélène. Le pluralism em Droit International Privé: richesses et faiblesses (Le funambule et l'arc-en-ciel). Recueil des Cours, v. 312, Leiden/Boston: Martinus Nijhoff Publishers, 2006.

GOLDSCHMIDT, Werner. Sistema y filosofia del Derecho Internacional Privado. Tomo I. Buenos Aires: Ediciones Jurídicas Europa-América, 1952, 2a ed.

GOSEPATH, Stefan. The global scope of justice. In: POGGE, Thomas W. (org.). Global justice. Malden, MA: Blackwell Publishing, 2001, pp. 145-168.

GUTZWILLER, Max. Le développement historique du Droit International Privé, Recueil des Cours, v. 29, 1929.

GUZMAN, Andrew T. Choice of law: new foundations, Georgetown Law Journal, ${ }^{\circ}$ 90, 2002, pp. 883-940.

HABERMAS, Jürgen. The postnational constellation: political essays (traduzido do original em alemão, de 1998, por Max Pensky). Cambridge, MA: The MIT Press, 2001.

HARTLEY, Trevor C. Mandatory rules: the Common Law approach, Recueil des Cours, v. 266, Leiden/Boston: Martinus Nijhoff Publishers, 1997.

HELD, David. Cosmopolitanism: Ideals and realities. Cambridge, Reino Unido: Polity Press, 2010.

HILL, Thomas. The importance of autonomy. In: KITTAY, E.; MEYERS, D. (eds.), Women and Moral Theory. Towata: Rowman and Allanheld.

JANDA, Richard. Toward cosmopolitan law. McGill Law Journal, v. 50, 2005, pp. 967984.

JAYME, Erik. Le droit international privé du nouveau millénaire: la protection de la personne humaine face à la globalisation, Recueil des Cours, vol. 282, Leiden/Boston: Martinus Nijhoff Publishers, 2000.

JONES, Charles. Global justice: Defending cosmopolitanism. Oxford: Oxford University Press, 1999. 
JOUBERT, Natalie. La notion de liens suffisants avec l'ordre juridique (Inlandsbezichung) en droit international privé. Paris: Litec, 2007.

JUENGER, Friedrich. Choice of law and multistate justice. Nova York: Transnational Publishers, 2005, special edition.

KAMBA, W. J. Comparative law: a theoretical framework. International \& Comparative Law Quarterly, n² 23, 1974, pp. 485-519.

KANT, Immanuel. Perpetual peace and other essays (trad. para o inglês: Ted Humphrey). Indianapolis: Hackett Publishing, 1983 (edição original de 1795).

Britannica, 1952.

. The science of right, Great Books of Western World. Londres:

KEGEL, Gerhard. Internationales Privatrecht, $6^{\mathrm{a}}$ ed., 1987.

KERVÉGAN, Jean-François. Le droit cosmopolitique comme droit, Logos, $\mathrm{n}^{\circ} 42$, Madrid, 2009, pp. 9-24.

LAFER, Celso. Prefácio à obra “A Era dos Direitos”, de Norberto Bobbio. Rio de Janeiro: Elsevier, 2004.

LAGARDE, Paul. Le principe de proximité dans le droit international contemporain, Recueil des Cours, t. I, Leiden/Boston: Martinus Nijhoff Publishers v. 196, t. I, 1986.

LALIVE, Pierre. Ordre public transnational (ou réellement international) et arbitrage international, Révue d'Arbitrage, 1986, pp. 329-372.

. Tendances et méthodes en Droit International Privé. Recueil des Cours, v. 155, Leiden/Boston: Martinus Nijhoff Publishers, 1977.

LEFLAR, Robert. Conflicts Law: more on choice-influencing considerations, California Law Review, vol. 54, n 4, 1966, pp. 1584-1598.

LORENZEN, Ernest G.. Territoriality, public policy and the Conflict of Laws, Yale Law Journal, v. 33, $n^{\circ} 7,1923$, pp. 736-751.

MCCLEAN, David. De conflictu legum - Perspectives on Private International Law at the turn of the century. Recueil des Cours, v. 282, Leiden/Boston: Martinus Nijhoff Publishers, 2000.

MCWHINNEY, Self-determination of peoples and plural-ethnic states (secession and state succession and the alternative federal option, Recueil des Cours, v. 294, Leiden/Boston: Martinus Nijhoff Publishers, 2002.

MICHAELS, Ralf. After the Revolution - Decline and Return of U.S. Conflicts of Laws. Durham: Duke Law Faculty Scholarship, Paper 2129, 2009. Disponível em: http://scholarship.law.duke.edu/faculty_scholarship/2129, acessado em 28.06.2011. 
MONACO, Gustavo Ferraz de Campos. Atribuição da guarda e suas consequências em Direito Internacional Privado. Tese de Doutorado. Faculdade de Direito da Universidade de São Paulo - USP, 2008.

MONTAIGNE. Essays, III, 9. In: Great Books of Western World. Londres: Britannica, 1952.

NAZO, Nicolau. Objeto e método do Direito Internacional Privado, São Paulo: Acervo do Departamento de Direito Internacional da FDUSP, 1952.

NUSSBAUM, Martha. Kant and Stoic Cosmopolitanism, The Journal of Political Philosophy, v. 5, $\mathrm{n}^{\circ} 1,1995$, p. 6.

O'NEILL, Onora. Agents of justice. In: POGGE, Thomas W. (org.). Global justice. Malden, MA: Blackwell Publishing, 2001, pp. 188-203.

POGGE, Thomas W. (org.). Global justice. Oxford: Blackwell, 2001.

. Realizing Rawls. Ithaca: Cornell University Press, 1989.

POST, Robert. Another cosmopolitanism - The Berkeley Tanner lectures. Nova York: Oxford University Press, 2006.

PILLET, Antoine. De l'ordre public en Droit International Privé. Kessinger Publishing, 2009 (edição original de 1890).

RAMOS, Rui Manuel Moura. Da lei aplicável ao contrato de trabalho internacional. Coimbra: Almedina, 1990.

Perspectiva do Direito Internacional Privado no limiar do novo século. In: DIAS, Jorge de Figueiredo (org.). Internacionalização do direito no novo século - Boletim da Faculdade de Direito da Universidade de Coimbra. Coimbra, Portugal: Coimbra Editora, 2009, pp. 127-144.

RAWLS, John. A theory of justice. Cambridge, Massachusetts: Harvard University Press, 1999, Revised edition.

. The Law of Peoples, Critical Inquiry, Autumm 1993.

REIMANN, Mathias. A new Restatement - for the international age, Indiana Law Journal, Indiana, v. 75, pp. 575-589, 2000.

Parochialism in American Conflicts Law, American Journal of Comparative Law, v. 49, n 3, pp. 369-389, 2001.

RIGAUX, François. La théorie des qualifications en droit international privé. Bruxelas: F. Larcier, 1956.

RODAS, João Grandino. Jus cogens em Direito Internacional, Revista da Faculdade de Direito da Universidade de São Paulo, vol. 69, nº 2, 1974, pp. 125-136. 
ROLIN, Henri. Vers un ordre public réelement international. In: Hommage d'une generatión de juristes au Président Basdevant. Paris: Pedone, 1960.

RUSSELL, Bertrand. A history of western philosophy. Nova York: Touchstone, 2007.

SANTOS, Boaventura de Sousa. Introdução: as tensões da modernidade ocidental. In: SANTOS, Boaventura de Sousa (org.). Reconhecer para libertar: os caminhos do cosmopolitismo multicultural. Rio de Janeiro: Civilização Brasileira, 2003, p. 429-461.

SAVIGNY, Friedrich Carl Von. System des Heutigen Römischen Rechts, vol. VIII (trad.: Ciro Mioranza). Ijuí: Editora Unijuí, 2004.

SCHEFFLER, Samuel. Boundaries and allegiances. Nova York: Oxford University Press, 2001.

SCHLESINGER, Rudolf; BAADE, Hans; HERZOG, Peter; WISE, Edward. Comparative Law. Nova York: Foundation Press, 1998, $6^{\mathrm{a}}$ ed.

SEN, Amartya. The idea of justice. Cambridge, Massachusetts: Harvard University Press, 2009.

SMITH, Adam. The theory of moral sentiments. Nova York: Penguin Classics, 2009.

Stanford Encyclopedia of Philosophy, disponível em: http://plato.stanford.edu.

TAN, Kok-Chor. Justice without borders: cosmopolitanism, nationalism, and patriotism. Cambridge: Cambridge University Press, 2004.

TANAKA, Aurea Christine. Princípios aplicáveis ao divórcio no Direito Internacional Privado: o caso dos brasileiros no Japão. Tese de Doutorado. Faculdade de Direito da Universidade de São Paulo - USP, 2005.

TIBURCIO, Carmen. Temas de Direito Internacional. Rio de Janeiro: Renovar, 2006.

TORRES, Ricardo Lobo. A afirmação do direito cosmopolita. In: DIREITO, Carlos Alberto Menezes; TRINDADE, Antonio Augusto Cançado; PEREIRA, Antônio Celso Alves. Novas perspectivas do Direito Internacional Contemporâneo - Estudos em homenagem ao Professor Celso D. de Albuquerque Mello. Rio de Janeiro: Renovar, 2008, pp. 919-939.

VALENTE DOS REIS, Gabriel. Direito concorrencial internacionalizado - entre a teoria dos efeitos e os efeitos da teoria. Revista de Direito Constitucional e Internacional, $\mathrm{n}^{\circ}$ 73, 2010, pp. 303-329.

. O Direito Internacional Privado e a teoria das qualificações: uma

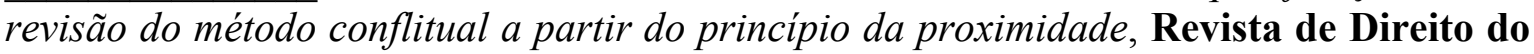
Estado - RDE, n ${ }^{\circ}$ 13, pp. 293-325. 
VALLADÃO, Haroldo. Direito Internacional Privado: em base histórica e comparativa, positiva e doutrinária, especialmente dos Estados americanos, vol. I, 5a ed., Rio de Janeiro: Freitas Bastos, 1980.

VALLINDAS, P. G. La structure de la règle de conflit. Recueil des Cours, v. 101, 1960.

VICENTE, Dário Moura. Método e fontes do Direito Internacional Privado. In: VICENTE, Dário Moura. Ensaios, vol. II, Coimbra: Almedina, 2005, pp. 7-37.

WALDRON, Jeremy. Cosmopolitan norms. In: POST, Robert (ed.). Another Cosmopolitanism, The Berkeley Tanner Lectures. Nova York: Oxford University Press, 2006, pp. 83-101.

WOLFF, Martin. Derecho Internacional Privado, trad. p/ o espanhol de A. M. López. Barcelona: Bosch, 1958.

YNTEMA, Hessel E. The hornbook method and the Conflict of Laws, Yale Law Journal, v. $37, n^{\circ} 4,1928$, pp. $468-483$. 